Latvijas Lauksaimniecības Universitāte

Latvia University of Life Sciences and Technologies

Veterinārmedicīnas fakultāte

Faculty of Veterinary medicine

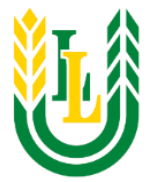

Gundega Gulbe

MIKROORGANISMU KLĀTBŪTNE GOVS (BOS PRIMIGENIUS TAURUS) PIENĀ BIOLOGISKAJĀ LAUKSAIMNIECİBĀ UN DABĪGU VIELU IETEKME UZ̉ GOVĪM AR SUBKLĪNISKO MASTİTU

\author{
DISTRIBUTION OF MICROORGANISMS IN BOVINE \\ (BOS PRIMIGENIUS TAURUS) MILK FROM ORGANIC FARMING \\ AND THE IMPACT OF NATURAL SUBSTANCES ON SUBCLINICAL \\ MASTITIS AFFECTED COWS
}

Promocijas darba KOPSAVILKUMS

Dr.med.vet. zinātniskā grāda iegūšanai

SUMMARY

of the doctoral thesis for the scientific degree of Dr.med.vet. 
Promocijas darba zinātniskā vadītāja:

Scientific supervisor:

Dr.med.vet., LLU profesore

\section{Anda Valdovska}

\section{Promocijas darbs izstrādāts:}

- LLU Veterinārmedicīnas fakultātes Pārtikas un vides higiēnas institūta mikrobiologijas laboratorijā;

- Rīgas Stradiña universitātes A. Kirhenšteina Mikrobiologijas un virusologijas institūtā;

- Rīgas Stradiña universitātes Anatomijas un antropoloǵijas institūta Morfologijas laboratorijā;

- VSIA "Paula Stradiña Klīniskā universitātes slimnīca" Apvienotajā laboratorijā Klīniskās Imunologijas centra Imunologijas laboratorijas nodaḷā;

- SIA "Piensaimnieku laboratorija" (Institūta iela 1, Ulbroka, Stopiṇu novads, Latvija).

\section{Research has been carried out at the:}

- Laboratory of Microbiology of the Institute of Food and Environmental Hygiene of the Faculty of Veterinary medicine the Latvia University of Life Sciences and Technologies;

- August Kirchenstein Institute of Microbiology and Virology the Rìga Stradiňs University;

- Laboratory of Morphology of the Institute of Anatomy and Anthropology the Rìga Stradiňs University;

- Laboratory of Immunology of the Clinical Immunology Center of the Central Laboratory the Pauls Stradiňs Clinical University Hospital;

- $\quad$ The Dairy Laboratory Ltd. (Instituta str. 1, Ulbroka, Stopinu region, Latvia).

\section{Oficiālie recenzenti:}

Official reviewers:

Dr.med.vet., LLU profesore Vita Antāne (Latvijas Lauksaimniecības universitāte / Latvia University of Life Sciences and Technologies)

Dr.sc.ing., LLU profesore Līga Skudra (Latvijas Lauksaimniecības universitāte / Latvia University of Life Sciences and Technologies)

Dr.biol., LU asociētā profesore Vizma Nikolajeva (Latvijas Universitāte / Latvia University) 
Promocijas darba izstrāde līdzfinansēta no Eiropas Savienības Sociālā fonda, un projekta „Dabīga imūnmodulatora ar antibakteriālu iedarbību mastīta ārstēšanai un profilaksei govīm izstrāde" īstenošana veikta ar ERAF līdzfinansējumu, vienošanās Nr. 2014/0016/2DP/2.1.1.1.0/14/APIA/VIAA/075.

Doctoral thesis has been worked out by financial support of ESF and the research "The effect of immunomodulation composition on systemic immune response and udder health in case of bovine subclinical mastitis" was funded by ERAF, project No. 2014/0016/2DP/2.1.1.1.0/14/APIA/VIAA/075.

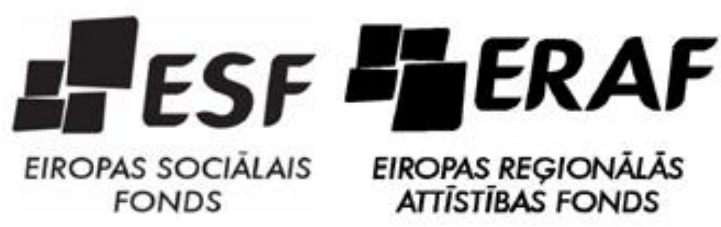

Promocijas darba aizstāvēšana notiks 2018. gada 14. septembrī, plkst. 13:00 LLU Veterinārmedicīnas fakultātē, Jelgavā, K.Helmaņa ielā 8, A300 auditorijā.

The defence of these Thesis will take place at the LLU Faculty of Veterinary Medicine, auditorium A300, on the September 14, 2018, at 13:00 o'clock.

DOI: 10.22616/lluthesis/2018.012 


\section{SATURA RĀDĪTĀJS}

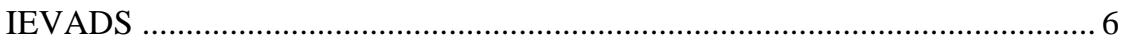

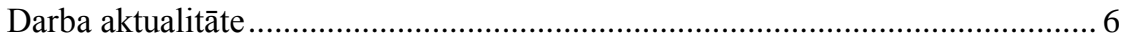

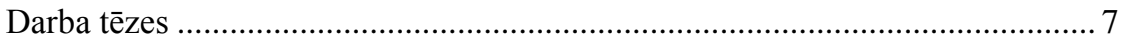

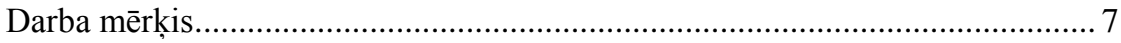

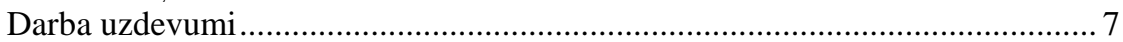

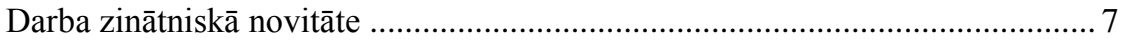

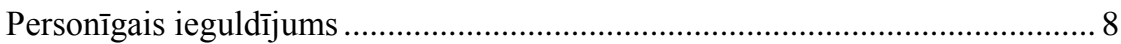

Pētījuma rezultātu aprobācija / Approbation of the research results .................. 9

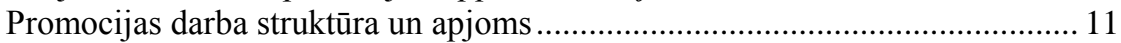

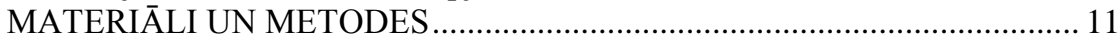

Pētījuma laiks, vieta un materiāla raksturojums ........................................... 11

Pētījumā izmantotās metodes..................................................................... 14

Pētījuma pirmajā etapā iegūto piena paraugu noṇemšana, transportēšana un nogādāšana laboratorijā .......................................................................... 14

Imūnmodulatoru antibakteriālās aktivitātes pārbaude pētījuma otrajā etapā .... 15 Govju veselības stāvokḷa uzraudzība un intramammāra preparātu ievadīšana

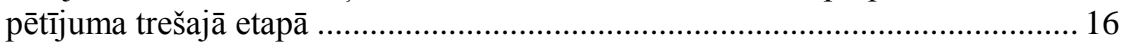

Pētījuma trešajā etapā iegūto paraugu izmeklējumi........................................ 16

Pētījuma pirmajā un trešajā etapā pielietotās mikrobiologisiskās testēšanas

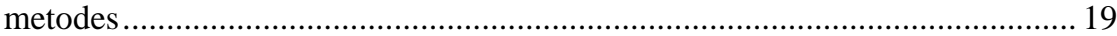

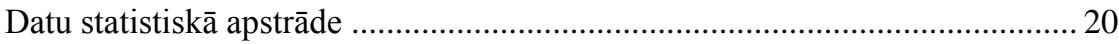

PĒTİJUMA REZULTĀTI UN DISKUSIJA .................................................... 22

1. Mikroorganismu klātbūtne govs pienā bioloǵiskajos piena ražošanas

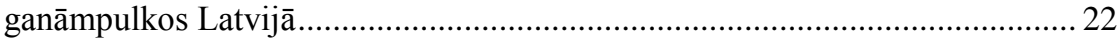

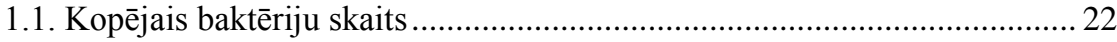

1.2. Piena paraugos izolētās baktērijas ............................................................. 24

2. Imūnmodulatoru komponentu un kompozīciju antibakteriālās aktivitātes

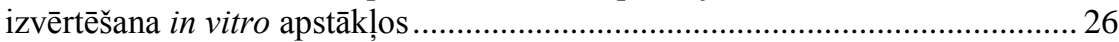

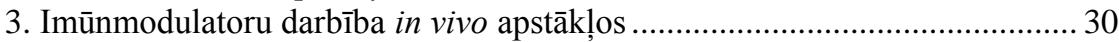

3.1. Mastīta ierosinātāji pienā ...................................................................... 30

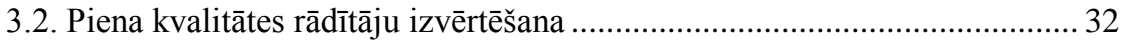

3.3. Govju veselības stāvoklis un piena vizuālās pārmainas.............................. 34

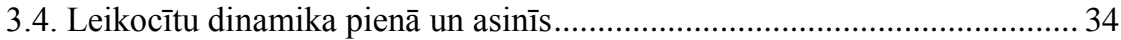

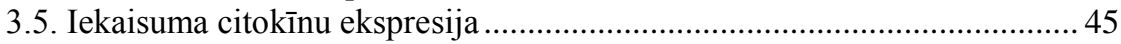

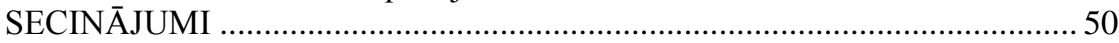

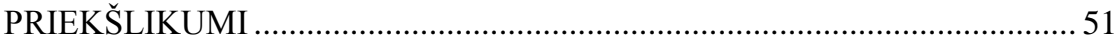




\section{CONTENT}

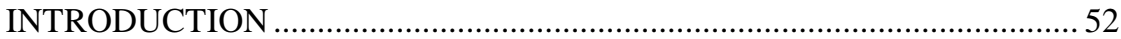

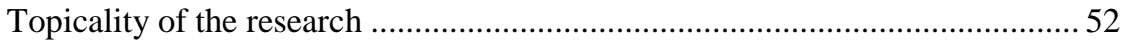

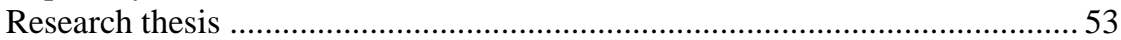

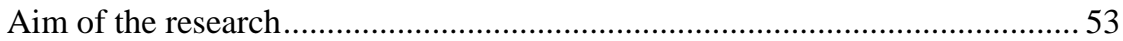

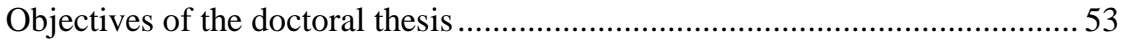

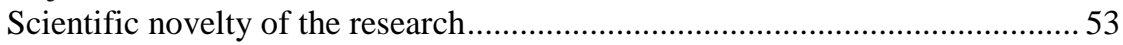

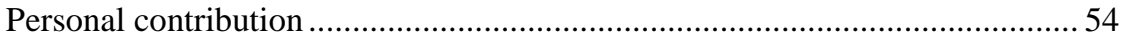

Structure and volume of the doctoral thesis ......................................................5

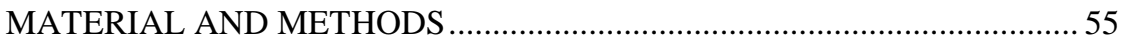

Time and object of the research and its characterization ..................................55

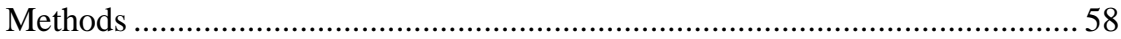

Sampling, transporting and delivering milk samples obtained in the first stage of

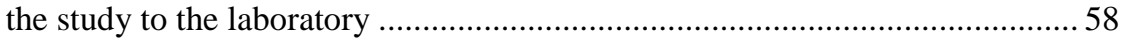

Measurements of antibacterial activity of immunomodulators in the second phase

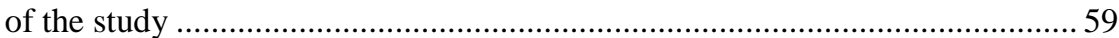

Clinical assessment of cow health status and infusions of intramammary preparations in the third phase of the study ...................................................59

Examination of the samples obtained in the third phase of the study ............... 60 Microbiological investigation methods used in the first and third stage of the

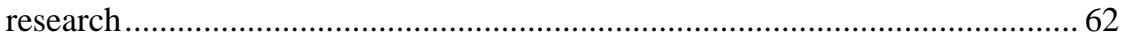

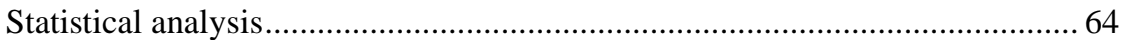

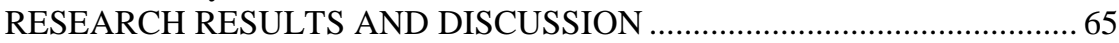

1. Distribution of microorganisms in bovine milk from organic farming in Latvia

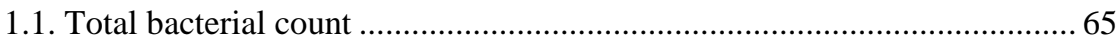

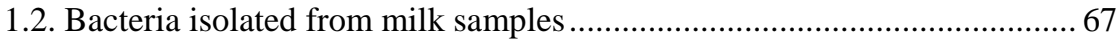

2. Evaluation of immunomodulator components and compositions antibacterial

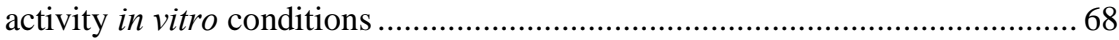

3. Immunomodulatory activity in vivo condition........................................ 70

3.1. Mastitis causing bacteria in milk ……..................................................... 70

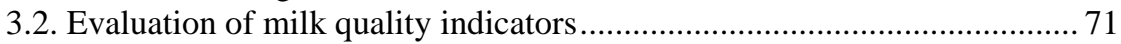

3.3. The bovine health and changes in the milk consistency .......................... 72

3.4. Leukocyte dynamics in milk and blood ................................................. 73

3.5. Expression of the inflammatory cytokines................................................ 77

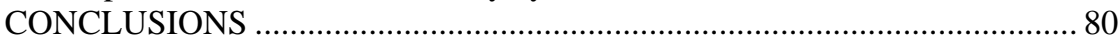

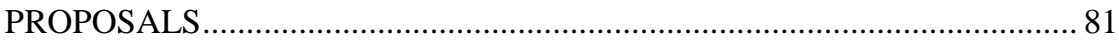




\section{IEVADS \\ Darba aktualitāte}

Dz̄̄vnieka imūnās sistēmas funkcionālais stāvoklis ir galvenais faktors, kas nosaka, vai pēc baktēriju invāzijas piena dziedzerī sāksies mastīts. Mastīts jeb tesmeņa iekaisums ir visbiežākā slimība, kura skar piena liellopu ganāmpulkus un ir galvenais iemesls ekonomiskajiem zaudējumiem piena ražošanā visā pasaulē (Maréchal et al., 2011), savukārt subklīniskais mastīts ir īpašs piena dziedzera stāvoklis, kam raksturīga ilgstoša zemas intensitātes infekcija un sekojoši piena dziedzera audu bojājumi ar piena kvalitātes samazināšanos. Mastīta ārstēšanas pamatā visā pasaulē joprojām ir antibiotiskie zāḷu līdzekḷli, taču terapijas kopējās izmaksas (ieskaitot produkcijas realizācijas ierobežojumus) ir visai dārgas, antibiotiku lietošanas efektivitāte pamazām krītas, turklāt ir saistīta ar būtisku kaitējumu sabiedrības veselībai kopumā, jo atliekvielu klātbūtne pienā veicina pret antibiotikām rezistento patogēno baktēriju celmu attīstību (Gyles, 2008; Persoons et al., 2012). Cīna pret baktēriju antimikrobiālās rezistences attīstību, kas ietver antibiotiku piesardzīgu un racionālu lietošanu, ir viens no prioritārajiem uzdevumiem cilvēku veselības aizsardzības nozarē un veterinārmedicīnā gan Latvijā, gan ES kopumā, taču, lai šo uzdevumu varētu īstenot, ir nepieciešamas alternatīvas metodes mastīta ārstēšanā (Izglītības un Zinātnes ministrija, 2017).

Eiropas Savienības dalībvalstīs govju saslimšanas gadījumos ar mastītu biologiskās saimniekošanas apstākḷlos rīcību nosaka Regula 834/2007 par biologiisko ražošanu un biolog̣isko produktu marḳešanu. Regulā noteikts, ka ganāmpulka profilakses nolūkos un dzînnieka slimības gadījumā jāpiemēro ārstēšana izmantojot fitoterapeitiskus un homeopātiskus līdzekḷus, un tikai tādos dzīvnieka saslimšanas gadījumos, kad iepriekšminētie ārstniecības līdzekḷi nedod vēlamo rezultātu, ir aţ̦auts pielietot ķīmiski sintezētas veterinārās zāles, tajā skaitā antibiotikas. Šì noteikuma pamatā ir princips, ka dzīvnieku veselību vislabāk iespējams uzturēt, veicinot dzīvnieku dabisko imūnsistēmas aizsardzību.

Šo problēmu dēḷ pēdējo gadu laikā intensīvi notiek pētījumi ar mērķi izveidot dabiskus antibakteriālus līdzekḷus. Nozīmīga alternatīva antibiotiku terapijai ir imūnmodulatori ar antibakteriālām īpašībām. Autori ir pierādījuši, ka baktericīdo vielu izmantošana ir efektīva arī govīm mastīta ārstēšanā (Kai et al., 2002; Cao et al., 2007; Klostermann et al., 2010; Soleimani et al., 2010; Espeche et al., 2012; Frola et al., 2012).

Lai gan govs piens satur plaša spektra mikroorganismus, un dạ̣ā gadījumu to klātbūtne ir saistīta ar piena dziedzeru iekaisumu jeb mastītu, galvenā nozīme hronisku subklīnisku infekciju pastāvēšanā ir govs imunolog̣iskajam stāvoklim. Pamatojoties uz šo pieņēmumu, ir noformulēta promocijas darba hipotēze: pielietojot govīm intramammāri dabīgas vielas ar imūnmodulējošām īpašībām, iespējams pastiprināt organisma vispārējo un piena 
dziedzeru lokālo imūnatbildi, kas rezultētos ar mastīta ierosinātāju klātbūtnes ierobežošanu tesmenī.

\section{Darba tēzes}

Promocijas darba hipotēze ir jāpierāda ar šādām tēzēm:

1) mikroorganismu populācija govju piena dziedzeros ir atkarīga no dažādiem faktoriem, tajā skaitā no gadalaika un ganāmpulka lieluma;

2) ierosinātāju veidam/sugai ir nozīmīga ietekme uz kopējo baktēriju skaitu un somatisko šūnu skaitu pienā;

3) govs piens satur daudzveidīgas vielas ar imūnmodulējošām un antibakteriālām īpašībām, kuru aktivitāti pret mastîta ierosinātājiem daḷêji ir iespējams novērtēt in vitro;

4) ievadot šīs dabīgās vielas govīm intramammāri, organismā tiek aktivizēta šūnu un humorālā imunitāte;

5) imunitātes aktivizēšana veicina patogēno baktēriju ierobežošanu govju piena dziedzeros.

\section{Darba mērḳis}

Promocijas darba mērḳis ir izpētīt bakteriālo daudzveidību pienā biologiskās ražošanas slaucamo govju ganāmpulkos un izveidot mastītu ierobežošanai līdzekli no komponentiem ar imūnmodulējošām īpašībām.

\section{Darba uzdevumi}

Lai šo mērḳi īstenotu, izvirzīti šādi pētnieciskie uzdevumi:

1) izpētīt govs piena bakteriālo daudzveidību biologiskās lauksaimniecības ganāmpulkos Latvijā un to sezonālo dinamiku;

2) noskaidrot prevalējošos subklīniskā mastīta ierosinātājus;

3) veikt antibakteriālās aktivitātes pārbaudi in vitro dabīgām vielām ar imūnmodulējošām īpašībām, kā arī to kompozīcijām, pret tipiskākajiem mastīta ierosinātājiem, pielietojot bedrīšu difūzijas metodi;

4) veikt vienas kompozīcijas ar antibakteriālu iedarbību izpēti in vivo apstākḷos, un pierādīt šīs kompozīcijas imūnmodulējošo darbību, kas rezultētos ar mastīta ierosinātāju ierobežošanu.

\section{Darba zinātniskā novitāte}

1) Veikts mikroorganismu klātbūtnes izvērtējums bioloğiskā lauksaimniecībā iegūtā govs pienā Latvijā saistībā ar ganāmpulku lielumu un gadalaiku. 
2) Sadarbojoties Latvijas Lauksaimniecības universitātes un Rīgas Stradiṇa universitātes pētniekiem, ir izstrādāta kompozīcija mastītu ierobežošanai no dabīgām piena izcelsmes vielām, t.i., pienskābes, lizocīma un $L$. helveticus glikopeptīda, kas paredzēta intramammārai ievadīšanai govju piena dziedzeros.

3) Pirmo reizi Latvijā govīm ir dinamikā izvērtēti gan leikocīti pienā, gan asin̄is, kā arī noteikts limfocìtu virsmas molekulu (CD4, CD8, CD16, CD19, CD25, CD45, CD69) saturošo šūnu skaits.

4) Pirmo reizi Latvijā veterinārmedicīnā izmantota imūnhistoķīmiskā metode govs tesmens sekrētā noritošo imunologisko procesu skaidrošanai, nosakot IL-1, IL-10, TNF- $\alpha$, kaspāzes-6 un beta defensīna-2 ekspresiju imūnšūnās.

5) Iegūti jauni dati par patologiskajiem procesiem piena dziedzeros govīm ar subklīnisko mastītu.

\section{Personīgais ieguldījums}

1) Pētījuma plāna sastādī̌sana.

2) Kontaktu nodibināšana ar biologiiskās ražošanas ganāmpulku īpašniekiem ar nolūku iegūt aţ̦auju piena paraugu noṇemšanai to saimniecībās.

3) Pētījumam izvēlēto bioloǵiskās ražošanas ganāmpulku apmeklēšana, informācijas iegūšana par pētījumam izvēlētajām govīm un piena paraugu nonemšana.

4) Piena paraugu transportēšana uz laboratoriju un sekojoša to mikrobiologiskā izmeklēšana.

5) Izolēto mastīta ierosinātāju tīrkultūru sagatavošana ilgstošai uzglabāšanai un tīrkultūru dzīvotspējas uzturēšana.

6) Imūnmodulējošo vielu un to kompozīiju antimikrobiālās aktivitātes mērījumi in vitro, kas ietver mastīta ierosinātāju tīrkultūru kultivēšanu.

7) Imūnmodulējošo kompozīciju iedarbības in vivo priekšizpēte uz dažām govīm.

8) Kompozīcijas GLP 810 intramammārā ievadīšana govju piena dziedzeros, piena paraugu noņemšana, transportěšana uz laboratorijām un sekojoša to mikrobiologiskā izmeklēšana.

9) Leikocītu diferenciālā skaitīšana piena sedimenta uztriepēs.

10) Mikrobiologisiskās, citoloǵiskās, imūnhistoḳimiskās, hematologiiskās un imunologiskās izmeklēšanas datu analīze un statistiskā apstrāde. 


\section{Pētījuma rezultātu aprobācija / Approbation of the research results}

\section{Zinātniskās publikācijas un tēzes / Scientific publication and theses:}

1. Gulbe G., Donina S., Saulīte V., Jermolajevs J., Peškova L., Svirskis Š., Valdovska A. (2017) The Effect of Immunomodulation Composition on Systemic Immune Response and Udder Health in Case of Bovine Subclinical Mastitis. Agronomy Research, 15(1): 144-154.

2. Gulbe G., Valdovska A., Saulīte V., Jermolajevs J. (2015) In Vitro Assessment for Antimicrobial Activity of Lactobacillus Helveticus and its Natural Glycopeptides against Mastitis Causing Pathogens in Dairy Cattle. DOI: 10.2174/1874070720150430E006, The Open Biotechnology Journal, 2015, 9, (Suppl 1-M6) 61-66 DOI: 10.2174/1874070701509010061.

3. Gulbe G., Valdovska A. (2014) Microbiological Content of Cow Milk Depending on Season and Herd Type in Latvian Organic Farms. Starptautiskās ikgadējās konferences raksti "Zinātne lauku attīstībai 2014” („Research for rural development 2014”), Nr. 1, 162.-168. lpp.

4. Gulbe G., Valdovska A. (2014) Diversity of Microscopic Fungi in the Raw Milk from Latvian Organic Farms. Latvijas Lauksaimniecības Universitātes Raksti, Nr. 31, 46.-53. lpp. Pieejams: file://C:/Users/gundega/Downloads/plua-2014-0006.pdf

5. Gulbe G., Valdovska A. (2012) Microbiological quality of cow's milk in organic farming, preliminary report. Starptautiskās ikgadējās konferences raksti “Zinātne lauku attīstībai 2012” (,Research for rural development 2012”), Nr. 1, 196.-202. lpp.

6. Gulbe G., Valdovska A. (2012) Probiotiku un to glikopeptīdu antibakteriālā iedarbība in vitro uz govju mastīta ierosinātājiem (Antimicrobial activity in vitro of probiotics and its glycopeptides against causative agents of bovine mastitis). Konferences „Veterinārmedicīnas zinātnes un prakses aktualitātes" Raksti, Nr. 1, 46.-51. lpp.

Pētijuma gaitā Latvijas Republikas Patentu valdē publicēts viens patents / During the research, one patent was published in the Patent Office of the Republic of Latvia:

Kompozīcija subklīniska mastīta ārstēšanai govīm. Jevgeṇijs Jermolajevs, Lilija Peškova, Gundega Gulbe, Vaira Saulīte, Simona Doniņa, Anda Valdovska (izgudrotāji). Int. Cl:: A61K31/185. RĪGAS STRADIN̦A UNIVERSITĀTE. Iesniegšanas datējums 2015-07-14. Patenti un Preču Zīmes, 2016 (2), LV 15071 A. (Starptautiskajā reg̣istrā publicēts ar nr. WO2017010856 (2017-01-19).) 
Pētījuma rezultāti aprobēti šādās starptautiskās zinātniskās konferencēs / Research results were approbated at the following international scientific conferences:

1. maijs 24-25, 2018 "Local cellular immune response to immunomodulating composition infusion in subclinical mastitis affected dairy cow mammary glands" 8th International Conference on Environmental, Industrial and Applied Microbiology "Bio Micro World 2018", Torremolinos, Malaga (Spānija);

2. novembris 24, 2017 "Dabīgas imūnmodulējošas kompozịcijas ietekme uz sistēmisko un lokālo imūnsistēmu govīm ar subklīnisko mastītu" ("Impact of the natural immunomodulating compozition on systemic and local immunosystem of subclinical mastitis affected cows") International annual conference "Research and Practice in Veterinary Medicine 2017", Jelgava (Latvija);

3. maijs 11-13, 2017 "The Effect of Immunomodulation Composition on Systemic Immune Response and Udder Health in Case of Bovine Subclinical Mastitis" 8th International Conference "Biosystems Engineering 2017", Tartu (Igaunija);

4. februāris 10, 2016 "Imūnmodulējošu kompozīciju antibakteriālās aktivitātes pie govju subklīniskā mastīta izvērtēšana in vivo" Latvijas universitātes 75. starptautiskā ikgadējā zinātniskā konference "Izglîtīiba zinātnei un praksei”, Rīga (Latvija);

5. jūlijs 24-26, 2014 "Intramammar application of Lactobacillus helveticus glycopeptides in lactating cows with subclinical mastitis" International Scientific Conference on Probiotics and Prebiotics - IPC2014, Budapešta (Ungārija);

6. maijs 21-23, 2014 "Microbiological content of cow milk depending on season and herd size in Latvian organic herds" 20. ikgadējā starptautiskā zinātniskā konference "Research for Rural Development 2014", Jelgava (Latvija);

7. augusts 26-30, 2013 "Potential of probiotics and their glycopeptides in treatment of bacterial mastitis in dairy cows" 64th Annual meeting of the European Federation of Animal Science, Nante (Francija);

8. novembris 22-23, 2012 "Probiotiku un to glikopeptīdu antibakteriālā iedarbība in vitro pret govju mastīta ierosinātājiem" ("Antimicrobial activity in vitro of probiotics and its glycopeptides against causative agents of bovine mastitis") Dzīvnieki. Veselība. Pārtikas higiēna: Starptautiskā ikgadējā konference "Veterinārmedicīnas zinātnes un prakses aktualitātes", Jelgava (Latvija);

9. novembris 4, 2012 "Antagonistic activity of probiotics and its glycopeptides against Staphylococcus spp." 1st congress of Baltic Microbiologists (CBM 2012), Rīga (Latvija); 
10. maijs 16-18, 2012 "Microbiological quality of cows' milk in organic farming (Preliminary report)" 20. ikgadējā starptautiskā zinātniskā konference "Research for Rural Development 2012", Jelgava (Latvija).

\section{Promocijas darba struktūra un apjoms}

Promocijas darbs noformēts 140 lappusēs ar 16 tabulām un 43 attēliem un sastāv no anotācijas, ievada, personīgā ieguldījuma, pētījuma rezultātu aprobācijas, literatūras apskata, materiāliem un metodēm, pētījuma rezultātiem, diskusijas, secinājumiem, priekšlikumiem un izmantotās literatūras saraksta ar 291 literatūras avotu. Darbam pievienoti 14 pielikumi.

\section{MATERIĀLI UN METODES}

Pētījums tika veikts trīs etapos, kur:

1) pirmajā etapā mēs izpētījām mikroorganismu klātbūtni govju pienā 14 biologiiskās lauksaimniecības ražošanas ganāmpulkos Latvijā;

2) otrajā etapā veicām dabīgu vielu ar imūnmodulējošām un antibakteriālām īpašībām izpēti in vitro apstākḷlos uz mastīta ierosinātāju kultūrām un atlasījām vienu optimālo kompozīciju;

3) trešajā etapā veicām kompozīciju in vivo izpēti pēc š̄ preparāta ievadīšanas intramammāri govīm ar subklīnisko mastītu.

\section{Pētījuma laiks, vieta un materiāla raksturojums}

Pētîjuma pirmajā etapā laika posmā no 2011. gada decembra līdz 2012. gada novembrim tika veikta svaigpiena paraugu iegūšana 14 bioloǵiskajās slaucamo govju novietnēs, iekḷaujot četrus Latvijas regionus: Kurzemē trīs ganāmpulki (iegūti ceturkšņu piena kopparaugi no 40 govīm), Vidzemē divi ganāmpulki (iegūti ceturkšņu piena kopparaugi no 40 govīm), Latgalē trīs ganāmpulki (iegūti ceturkšn,u piena kopparaugi no 41 govs), Zemgalē seši ganāmpulki (iegūti ceturkšņu piena kopparaugi no 106 govīm), tātad kopumā izmeklējot ceturkšnu piena kopparaugus no 227 govīm.

Ganāmpulku lielums variēja no 3-120 slaucamajām govīm vienā novietnē, un turpmākai rezultātu apkopošanai tos iedalījām šādās grupās:

- $\quad$ A grupa - mazie ganāmpulki ar 3-30 slaucamajām govīm. Šajā grupā analizējām četru ganāmpulku piena paraugus ar izmeklēto govju piena kopparaugu skaitu $\mathrm{n}=86$;

- B grupa - vidējie ganāmpulki, ar 31-60 slaucamajām govīm. Grupā analizējām piecu ganāmpulku piena paraugus ar izmeklēto govs piena kopparaugu skaitu $n=244$; 
- C grupa - lielie ganāmpulki ar 61-120 slaucamajām govīm. Šajā grupā analizējām piecu ganāmpulku piena paraugus ar izmeklēto govs piena kopparaugu skaitu $\mathrm{n}=210$.

No katra ganāmpulka, tika izvēlētas 15 laktējošas govis, pēc iespējas iekḷaujot piecas veselas, piecas ar nedaudz/īslaicīgi paaugstinātu somatisko šūnu skaitu (SŠS) un piecas ar hronisku subklīnisku mastītu. Ganāmpulkos, kuros slaucamo govju skaits bija mazāks par 15, paraugus noṇēmām no visu laktējošo govju tesmeņa ceturkšņiem. Ja paraugu ņemšanas reizē kāda no pētījumā iekḷautajām govīm bija cietstāvoša vai likvidēta, ja iespējams, pētījumā tika iekḷauta cita, tai līdzvērtīga (ņemot vērā laktāciju un tesmeņa veselības stāvokli) laktējoša govs. Sekojoši no šīm govīm tika izmeklēti piena paraugi četras reizes gadā, kopā izmeklēšanai veidojot 540 ceturkšņu koppiena paraugus, t.i., ziemā 140 paraugus, pavasarī - 134, vasarā - 160 un ruden̄i 106 paraugus.

Pētījuma otrajā etapā mēs veicām dabīgu vielu ar imūnmodulējošām īpašībām antibakteriālās aktivitātes noteikšanu in vitro pret tipiskākajiem mastīta ierosinātājiem, un to īstenojām laika posmā no 2012. gada maija līdz 2015. gada maijam.

Imūnmodulatoru komponentu, kompozīciju un kontroles preparātu antibakteriālo aktivitāti pārbaudījām uz septiṇām baktēriju kultūrām, kas izolētas no aseptiski noṇemtiem piena paraugiem - govīm no biolog̣iskās lauksaimniecības ražošanas ganāmpulkiem, kurām pētījuma pirmā etapa laikā konstatēts subklīniskais mastîts. Šo septiņu mikroorganismu celmu identifikācija tika veikta Pārtikas drošības, dzīvnieku veselības un vides zinātniskajā institūtā "BIOR", pielietojot "MALDI Biotyper" (Bruker, Vācija) un "BBL Crystal Gram-positive and Enteric/Nonfermenter ID" (Becton, Dickinson and Company, ASV) mikroorganismu identifikācijas sistēmas. Identificētie celmi, kurus izmantojām in vitro pētījumos, bija:
1) S. aureus (tipisks celms);
2) S. aureus (mazo koloniju variants);
3) S. saprophyticus;
4) S. haemolyticus;
5) E. coli;
6) Serratia liquefaciens;
7) Citrobacter freundii.

Pētījumā pielietotie imūnmodulatoru komponenti un to kompozīcijas, ar dažiem izṇēmumiem ${ }^{1}$, tika izgatavoti Rịgas Stradiņa universitātes A. Kirhenšteina Mikrobiologijas un virusolog̣ijas institūtā (RSU, MVI):

1) lizocīms (AppliChem GmbH, Vācija);

2) laktoferīns (Alfa Aesar, Thermo Fisher Scientific, Vācija);

${ }^{1}$ Lizocīms (AppliChem GmbH, Vācija), laktoferīns (Alfa Aesar, Thermo Fisher Scientific, Vācija) un pienskābe (BDH Prolabo, İrija) 
3) laktoferīns (no pirmpiena);

4) pienskābe (BDH Prolabo, Īrija);

5) kazeīns (no pirmpiena);

6) lielās ceḷtekas (Plantago major) koncentrāta šķīdums (1:3 ar $0.9 \mathrm{NaCl})$;

7) ārstniecības kumelītes (Matricaria recutita) ekstrakts;

8) L. helveticus glikopeptīds $\left(10^{9} \mathrm{kvv} \mathrm{g}^{-1}\right)$;

9) L. reuterii (dzīvotspējīgās liofilizētās pienskābes baktērijas $10^{7} \mathrm{kvv} \mathrm{g}^{-1}$ );

10) $P$. pentosaceus (dzīvotspējīgās liofilizētās pienskābes baktērijas $\left.10^{7} \mathrm{kvv} \mathrm{g}^{-1}\right)$;

11) L. helveticus glikopeptīds $5 \%$ un kazeīns $95 \%$;

12) L. helveticus glikopeptīds 5\% un lizocīms $95 \%$;

13) lizocīms $100 \mathrm{mg}$, laktoferīns $100 \mathrm{mg}$, L. helveticus glikopeptīds $10 \mathrm{mg}$, pienskābe $1 \mathrm{~mL}$;

14) lizocīms $100 \mathrm{mg}$, laktoferīns $100 \mathrm{mg}$, L. helveticus glikopeptīds $10 \mathrm{mg}$, pienskābe $1 \mathrm{~mL}$; ceḷtekas koncentrāts $1 \mathrm{~mL}$;

15) L. reuterii glikopeptīds $90 \%$, lizocīms $10 \%$;

16) B. lactis glikopeptīds $90 \%$, lizocìms $10 \%$;

17) L. plantarum glikopeptīds $90 \%$, lizocīms $10 \%$;

18) L. helveticus glikopeptīds $90 \%$, lizocīms $10 \%$;

19) L. helveticus, pirmpiena hidrolizāts $95 \%$, lizocīms $5 \%$;

20) pepsīns, tripsīns, kazeīna hidrolizāts (no piena un pirmpiena);

21) piena olbaltumvielu polipeptīdi un lizocīms (no piena un pirmpiena), beta-glikāns, pienskābe un L. helveticus glikopeptīds;

22) kompozīcija GLP 810 (L. helveticus glikopeptīds $10 \mathrm{mg}$, lizocīms $300 \mathrm{mg}$, pienskābe $500 \mathrm{mg}$ ).

Visiem komponentiem un kompozīcijām, pirms izmantošanas in vitro un in vivo pētījumos, pievienojot sterilu nātrija karbonāta šḳ̄īumu $\left(\mathrm{Na}_{2} \mathrm{CO}_{3}\right), \mathrm{pH}$ tika noregulêts uz 6.3, kas, kā liecina autoru (Davies et al., 1969) pētījumi, nodrošina optimālu vidi un augstu aktivitāti lizocīma darbībai.

Kā kontroles preparātus in vitro pētījumiem mēs izmantojām:

1) Synulox LC (Pfizer Italiana S.R.L., Itālija), kas ir suspensija ievadīšanai tesmenī laktējošām govīm un satur sekojošas aktīvās vielas - amoksicilīna trihidrāts, kālija klavulanāts un prednizolons;

2) Tetra-Delta (Pfizer Animal Health Ltd., Apvienotā karaliste), kas ir suspensija ievadīšanai tesmenī laktējošām govīm un satur sekojošas aktīvās vielas - novobiocīna nātrija sāls, neomicīna sulfăts, prokaīna penicilīns, dihidrostreptomicīna sulfâts un prednizolons;

3) Eurofit gel (Slovenska Yooveterinarna Homeopaticka Spolocnost s.r.o., Slovēnija), kas ir homeopātiskās veterinārās zāles, paredzētas intramammārai aplikācijai laktējošām govīm un satur sekojošas aktīvās vielas - Phytolaca decandra, Hepar, sulphur, Silicea, Sepia officinalis, Thuya occidentalis, Calcarea phosphorica, Pulsatilla, Iodum, 
Cantharis, Phosphorus, Baptisia tinctoria, Echinacea angustifolia, Acidum nitricum, Phellendrum aquaticum, Arnica Montana un Bryonia; 4) $\quad 0.9 \%$ nātrija hlorīda ( $\mathrm{NaCl} 0.9 \%$ ) šḳīdumu ūdenī (negatīvā kontrole).

Sekojoši pētījuma 3. posma in vivo pētîjumos mēs pārbaudījām kompozīciju GLP 810, un š̄ preparāta vienas devas sastāvā tika iekḷautas sekojošas sastāvdalas: Pienskābe - 500 mg, Lizocīms - 300 mg, Glikopeptīdi $10 \mathrm{mg}, \mathrm{kā}$ arī 0.9 \% nātrija hlorīda šķ̄īdums ūdenī - $10 \mathrm{~mL}$.

Pētījuma trešo etapu, kura laikā mēs veicām optimālās imūnmodulatoru kompozīijas GLP 810 in vivo aktivitātes izpēti desmit govīm, mēs īstenojām laikā no 2015. gada 26. maija līdz 30. jūnijam vienā konvencionālās lauksaimniecības ražošanas slaucamo govju novietnē Latvijā veterinārmedicīnas prakses ietvaros.

Novietnē ar 265 slaucamajām govīm darbojās piesietā turēšanas sistēma un slaukšana piena vadā tika organizēta divas reizes dienā. Klīniskajiem izmēginājumiem mēs atlasījām 10 govis, kuras atradās laktācijas vidus posmā ${ }^{1}$ (218 56 dienas) un anamnēzē tām bija paaugstināts SŠS, t.i., 300 tūkst. un vairāk šūnu $\mathrm{mL}^{-1}$ vismaz 2 mēnešus pēc kārtas. Septinas no atlasītajām govīm bija ar izslaukumu 4-8 tūkst. kg, un trīs govis - ar izslaukumu 9-12 tūkst. kg iepriekšējā laktācijā. Govis atradās 3.-4. laktācijā un bija dažādu šķirņu: 5 govis bija Holšteinas melnraibās, 3 - Latvijas brūnās, 1- Holšteinas sarkanraibā un 1 Dānijas sarkanā govs.

Pētījumam atlasītās govis netika saṇēmušas nekādu ārstēšanu vismaz 30 dienas pirms izmēginājuma uzsākšanas, un nevienai no tām netika diagnosticēta cita saslimšana, izṇemot subklīnisku mastītu, un vispārīgās veselības izmeklēšanas laikā mēs neatradām tām nozīmīgas klīniskas atradnes. Uzsākot in vivo pētījumu, nevienai govij pienā nebija novērojamu vizuālu pārmaiṇu.

\section{Pētījumā izmantotās metodes}

\section{Pētījuma pirmajā etapā iegūto piena paraugu noṇemšana, transportēšana un nogādāšana laboratorijā}

No biologiiskajām saimniecībām iegūtos piena paraugus mikrobiologiiskajai izmeklēšanai mēs noṇēmām tajā pašā dienā vai 2 nedēļu laikā pēc piena paraugu n,emšanas piena kvalitātes pārraudzības programmas ietvaros. Paraugus savācām sterilos $6 \mathrm{~mL}$ tilpuma stobros (Weihai Hongyu Medical Devices Co., Ltd, Ķ̄ña) pēc aseptiskas tehnikas (Bradley et al., 2012), noṇemot pa vienam piena paraugam no katras izvēlētās govs visiem laktējošajiem tesmeņa ceturkšniem kopā (iegūstot kopparaugu). Lai gan kopparauga izmeklējumiem ir

${ }^{1}$ Laktācijas vidus posms nozīmēe, ka ir pagājušas vairāk nekā 60 dienas pēc govs atnešanās, un ir palikušas vismaz 90 dienas pirms paredzamās cietlaišanas (Moran, 2012) 
augsts specifiskums (>97\%), tomēr jārēḳinās ar samazinātu testa jutību (Reyher, Dohoo, 2011).

Pēc noṇemšanas paraugi nekavējoties tika nogādāti Latvijas Lauksaimniecības universitātes aǵentūras "Biotehnolog̣ijas un Veterinārmedicīnas zinātniskais institūts "Sigra"” (Sigulda, Latvija) mikrobiologijas laboratorijā. Paraugus transportējām aukstuma somā, saglabājot temperatūru $4-8{ }^{\circ} \mathrm{C}$ robežās. Paraugus ievietojām saldētavā $-20{ }^{\circ} \mathrm{C}$ temperatūrā, kur uzglabājām 2-6 nedēlas, t.i., līdz tika uzsākta paraugu mikrobioloǵiskā izmeklēšana. Pieņemot lēmumu paraugus sasaldēt un izmeklēšanu veikt pakāpeniski 2-6 nedēḷu laikā, mēs balstījāmies uz autoru (Murdough et al., 1996) veiktajiem pētījumiem, kas apliecina, ka, uzglabājot paraugus līdz 6 nedēḷām $20{ }^{\circ} \mathrm{C}$, uz biežāk izplatītajiem mastīta ierosinātājiem (S. aureus, KNS, Streptococcus spp., Corynebacterium bovis un E. coli) saldēšana neatstāj būtisku ietekmi. Citi autori (Petzer et al., 2012) konstatējuši vēl ilgāku periodu, kurā mastīta ierosinātāju dzīvotspēja nesamazinās: piem., S. agalactiae - 12 nedēlas, E. coli - 16 nedēlas, bet koagulāzes negatīvie stafilokoki (KNS) - 18 nedēlas.)

Gan kopparaugus, gan paraugu atšķaidījumus sākotnēji uzsējām uz četrām cietajām barotnēm, kopumā veicot 7560 primāros uzsējumus. Turpmākā bakterioloǵiskā izmeklēšana tika veikta saskaṇa ar attiecīgo metodiku, lai noteiktu baktēriju skaitu un veiktu to identifikāciju. Rezultātā mēs ieguvām 400 baktēriju izolātus, no kuriem septiņu tipiskāko subklīniskā mastīta ierosinātāju kultūras pielietojām turpmākajos pētījumos.

\section{Imūnmodulatoru antibakteriālās aktivitātes pārbaude pētījuma otrajā etapā}

Imūnmodulatoru antibakteriālās aktivitātes pārbaudi uz septinuu mastīta ierosinātāju mikroorganismu tīrkultūrām veicām pielietojot bedrīšu-difūzijas metodi (angl. well diffusion method) (Valgas et al., 2007; Tejero-Sariñena, 2012).

Baktēriju kultūras $0.1 \mathrm{~mL}$ apjomā ienesām sterilās $100 \mathrm{~mm}$ Petri platēs un pārlējām ar $20 \mathrm{~mL}$ Millera-Hintona agara (Mueller-Hinton agar, Oxoid, Lielbritānija) barotni, uzman̄̄gi sajaucām. Agarā izgriezām bedrītes $6 \mathrm{~mm}$ diametrā, kurās iepildījām $60 \mu \mathrm{L}$ pārbaudāmā šḳīduma. Plates sagatavojām 3 atkārtojumos, inkubējām aerobos apstākḷাos $24 \mathrm{~h} 37^{\circ} \mathrm{C}$ un izmērījām baktēriju augšanas nomākuma jeb antibakteriālās aktivitātes zonas diametru. Ja nomākuma zonas diametrs bija mazāks nekā $0.1 \mathrm{~mm}$, konstatējām, ka nomākuma nav un pārbaudītajam šķīdumam nepiemīt antibakteriāla aktivitāte pret pielietoto baktēriju kultūru. Iepriekš minētie izmeklējumi tika veikti 3 atkārtojumos, kopumā analizējot 546 reakcijas.

Kopumā izmantojām 10 imūnmodulējošās vielas jeb komponentus, 12 šo vielu kompozīcijas, kā arī četrus kontroles preparātus, no kuriem trīs bija pozitīvā kontrole (Synulox LC, Tetra Delta un Eurofit Gel) un viens bija negatīvā kontrole $(0.9 \% \mathrm{NaCl})$. Uznesot minētās imūnmodulējošās vielas un kontroles preparātus uz asins agara barotnes (kas saturēja 5\% govju asiṇu) un veicot inkubāciju, mēs 
pārbaudījām to sterilitāti un hemolītisko aktivitāti; šīs pārbaudes veicām trīs atkārtojumos, kopumā analizējot 78 paraugus.

\section{Govju veselības stāvokḷa uzraudzība un intramammāra preparātu ievadīšana pētījuma trešajā etapā}

Pētījuma 3. etapā tika atlasītas desmit govis, kuras sadalījām divās grupās, pa piecām govīm katrā. Eksperimentālās grupas govīm (kopā 19 ceturkšn,os) veicām kompozīcijas GLP 810 infūziju $10 \mathrm{~mL}$ apjomā trīs reizes ar $48 \mathrm{~h}$ intervālu (1., 3. un 5. pētījuma dienā). Kontroles grupas govīm (kopā 19 ceturkšņos) katrā ceturksnī intramammāri ievadījām kontroles $0.9 \% \mathrm{NaCl}$ šḳīdumu $10 \mathrm{~mL}$ apjomā trīs reizes ar 48 h intervālu (1., 3. un 5. pētījuma dienā). Infüzijas tika veiktas pēc rìta slaukšanas laikā no pl. 4:00-6:00. Govju veselības stāvokḷa uzraudzība tika veikta katru dienu no 1 . līdz 7. dienai, kā arī 14. un 21. dienā, atzīmējot veidlapā izmaiņas sekojošos parametros:

1) sistēmiskas izmaiņas govju klīniskajā stāvoklī (ḳermeņa temperatūra, izslaukums, apetīte);

2) piena dziedzeru klīniskais stāvoklis (apsārtis, ciets, sāpīgs, ar paaugstinātu temperatūru);

3) piena vizuālais izskats (ar pārslām, ar recekḷiem, ūdeņains).

Gan kontroles šḳīdums, gan imūnmodulatoru kompozīcijas tika ievadītas caur pupa kanālu, izmantojot katram ceturksnim individuālu vienreizlietojamu pupa kanulu J-12 (Jorgensen Laboratories, USA), kas uzliekama uz šlıirces. Pirms preparāta ievadīšanas pupa galu noslaucījām ar dezinficējošu vienreizējās lietošanas salveti un atslaucām četras līdz sešas piena strūklas. Pēc preparāta ievadīšanas veicām tesmeņa masāžu augšupvirzienā, kas veicina preparāta izkliedēšanos piena dziedzerī, kā arī novietnes darbinieks veica pupu iemērkšanu jodu saturošā dezinficējošā šḳīdumā, īstenojot rutīnas tesmeņu higiēnas pasākumu.

Piena paraugus no katra piena dziedzera noṇēmām 5 reizes, t.i., 1. dienā (pirms infūzijas veikšanas), 3., 5., 7. un 14. pētījuma dienā. Asins paraugus no astes vēnas (latīn., vena caudalis mediana) katrai govij mēs noṇēmām 4 reizes, t.i., 1. dienā (pirms infūzijas veikšanas), 3., 7. un 21. pētījuma dienā.

\section{Pētījuma trešajā etapā iegūto paraugu izmeklējumi}

Kopumā 3. etapā mēs ieguvām pētījumam 426 piena paraugus, kuriem tālāk veicām sekojošus izmeklējumus:

1) nosacīti patogēnās mikrobiotas un Lactobacillus spp. analīze - paraugus savācām sterilos stobros; primārajiem ceturkšṇu piena paraugiem veicām atšķaidījumu sērijas pagatavošanu, iegūstot 570 sekundāros paraugus. Primāro piena paraugu uzsējumus veicām uz piecām cietajām barotnēm, un veicām bakteriologiskos izmeklējumus, lai noteiktu kopējo baktēriju 
skaitu, Streptococcus spp., Staphylococcus spp., Enterobacteriaceae dzimtas mikroorganismu skaitu un E. coli klātbūtni pienā, kā arī Lactobacillus spp. baktēriju skaitu. Mikrobiologiskos izmeklējumus veicām LLU VMF Pārtikas un vides higiēnas institūta mikrobiologijas laboratorijā;

2) somatisko šūnu diferenciālā skaitīšana - paraugus savācām sterilos centrifugēšanas stobros. Pielietojot gaismas mikroskopiju, mēs veicām diferenciālo šūnu skaitīšanu 137 ceturkšņu piena paraugu uztriepēm, nosakot tajās leikocītu populācijas. Izmeklējumus veicām LLU VMF Pārtikas un vides higiēnas institūta mikrobiologijas laboratorijā;

3) imūnhistoḳīmiskie izmeklējumi - paraugu sagatavošanu un piena sedimenta uznešanu uz priekšmetstikliniem veicām LLU VMF Pārtikas un vides higiēnas institūta mikrobiologijas laboratorijā, bet uztriepju krāsošana tika īstenota Rīgas Stradiṇa Universitātes Anatomijas un antropoloǵijas institūta Morfologijas laboratorijā. 345 ceturkšņu piena paraugiem tika noteikta iekaisuma citokīnu IL-1, IL-10, TNF- $\alpha$, antibakteriālā peptīda BD-2 un kaspāzes-6 ekspresēto šūnu skaits;

4) piena kvalitātes izmeklējumi - paraugus savācām sterilās laboratorijas pudelēs bez konservanta, un tâlākā izmeklēšana tika veikta SIA "Piensaimnieku laboratorija" (Ulbroka, Latvija); 175 ceturkšņu piena paraugiem tika noteikts somatisko šūnu skaits, kopējais baktēriju skaits, tauku saturs, olbaltumvielu saturs, laktozes saturs, un $\mathrm{pH}$.

Somatisko šūnu skaits tika noteikts ar fluorescences optoelektronisko metodi uz ierīces Fossomatic FC (Foss AS, Vācija) saskaņā ar standarta LVS EN ISO 13366-2:2007 "Piens. Somatisko šūnu skaita noteikšana. 2.daḷa: Norādījumu par fluorescentoptoelektronisko skaitītāju ekspluatāciju” prasībām.

Baktēriju kopskaita noteikšana tika veikta ar elektronisku iekārtu "BactoScan FC" (FOSS Electric AS, Vācija), kas ir automātiska baktēriju šūnu skait̄̄̌sanas ierīce, kuras darbības pamatā ir plūsmas citometrija. Metode ir validēta, paredzēta piena higiēniskās kvalitātes kontrolei.

Tauku, laktozes un olbaltumvielu satura noteikšana pienā (\%) tika veikta ar infrasarkanās spektroskopijas metodi saskaṇā ar ISO standarta 9622:1999 "Whole milk. Determination of milk fat, protein and lactose contentGuidance on the operation of mid-infrared instruments" prasībām.

pH noteikšana tika veikta ar $\mathrm{pH}$ metru, kura princips ir piena elektrovadītspējas noteikšana un rezultātu izteikšana $\mathrm{pH}$.

Somatisko šūnu diferenciālo skaitīšanu mēs veicām pēc autoru (Fragkou et al., 2014) aprakstîtās metodikas. Iegūtos $10 \mathrm{~mL}$ piena paraugus sterilos centrifugēšanas stobriņos (tilpums $10 \mathrm{~mL}$, Plastiques Gosselin, Francija) centrifugējām $1500 \times \mathrm{rpm} 10$ minūtes ilgi. Ar automātisko pipeti atsūcām šķidrumu, tad aptuveni $10 \mu \mathrm{L}$ no šūnu suspensijas uznesām uz priekšmetstikliṇa, un vienmērīgi izklājām. Uztriepes nožāvējām istabas temperatūrā un krāsojām ar Dip Quick krāsu (Rapid Differential Stain kit) saskaṇā ar ražotāja (Astral 
Diagnostics incorp., USA) instrukciju. Katru uztriepi izskatījām gaismas mikroskopā 40 un 100 reižu lielā palielinājumā, saskaitot 100-200 šūnas un nosakot to piederību piena šūnu populācijām: limfocītiem, makrofāgiem un polimorfonukleārajiem leikocītiem.

Piena šūnu imūnhistoḳīmisko izmeklēšanu veicām, lai novērtētu iekaisuma citokīnu interleikīna 1 (IL-1) un audzēju nekrozes faktora-alfa (TNF- $\alpha$ ), iekaisumu inhibējošā citokīna interleikīna 10 (IL-10) un antibakteriālā peptīda beta-defensīna 2 (BD-2) ekspresiju, kā arī apoptozes marḳieri kaspāzi-6, pielietojot pielāgotu biotīna - streptavidīna imūnhistoķīmisko metodi (Hsu et al., 1981). Izmeklējumu veikšanai tika sagatavotas uztriepes - no sedimenta, kas iegūts, pienu centrifugējot $1500 \mathrm{rpm}$ x $10 \mathrm{~min}$. Kopumā no 23-iem tesmeṇu ceturkšņu (19 eksperimenta un 4 kontroles grupas) piena paraugiem sagatavotās 345 uztriepes tika izmantotas tālākai krāsošanai un morfologiskai izpētei Rīgas Stradiņa universitātes Anatomijas un Antropologiijas institūta Morfoloğijas laboratorijā. Preparātu imūnhistoḳīmiskajā krāsošanā pielietojām sekojošas primāāās antivielas: trušu poliklonālās IL-1 $\alpha$ (kods AB17281, atšķaidīšanas pakāpe 1:200, Abcam, Lielbritānija) un IL-10 (kods Ab34843, 1:400, Abcam, Lielbritānija), kazu poliklonālās beta-defensīna 2 (kods AF2758, 1:100, RD Systems, Lielbritānija), trušu monoklonālās kaspāze-6 (kods Ab52951, 1:250, Abcam, Lielbritānija) un trušu poliklonālās audzēju nekrozes faktora-alfa (kods ab6671, 1:100, Abcam, Lielbritānija) un ar biotīnu saistītās sekundārās antivielas (LSAB+LINK, kods K1015, DakoCytomation, Dānija). Pozitīvas reakcijas gadījumā struktūras nokrāsojās brūnas. Lai izvairītos no artefaktiem, šūnu kodolus un fonus iekrāsojām ar hematoksilīnu (Mayers Hematoxylin, kods 05M06002, Bio-Optica, IT).

Perifērās asins paraugu izmeklējumi tika veikti Paula Stradiņa Klīniskās universitātes slimnīcas Apvienotajā laboratorijā Klīniskās Imunolog̣ijas centra Imunologijas laboratorijas nodạ̣ā. Asins paraugi tika izmeklēti ar vairākām metodēm, nosakot tajos imūnkompetento šūnu aktivitātes rādītājus, t.i., kopējo leikocītu skaitu un to populācijas (segmentkodolainie leikocīti, stabiṇkodolainie leikocīti, limfocīti, monocīit), kā arī limfocītu populāciju (CD16+, CD19+) un subpopulāciju (CD4+, CD8+) aktivitātes (CD25+, CD45+, CD69+) marḳierus (gan šo šūnu absolūto skaitu asinīs, $\mathrm{mL}^{-1}$, gan to procentuālo daḷu). Kopējais leikocītu skaits asinīs tika noteikts ar 5dalı̄ịu diferenciālās hematologíjas ierīci Pentra 60 (Horiba ABX Diagnostics, Japan) saskaņā ar standarta protokolu. Asins formelementu apskate un leikocitārās formulas noteikšana tika veikta, analizējot asins uztriepes gaismas mikroskopā 100 reižu palielinājumā. Limfocītu populāciju un subpopulāciju aktivitātes raksturošana tika veikta, izmantojot šūnu marķieru (CD4+, CD8+, CD16+, CD19+, CD25, CD45+ un CD69) analīzes. Šūnu markieru identificēšanai tika pielietota fluorescences-aktivēto šūnu škirošanas metode (FACS) un atbilstošas peḷu antivielas saskaņā ar ražotāja (FACS Calibur, Becton, Dickinson and Company, ASV) protokolu. 


\section{Pētījuma pirmajā un trešajā etapā pielietotās mikrobioloğiskās testēšanas metodes}

Lai samazinātu mikroorganismu kopējo skaitu tilpuma vienībā, kas atvieglotu mikroorganismu augšanas novērošanu un to koloniju skaitīšanu pēc uzsējumu inkubācijas, veicām secīgu decimālšks̄īdumu sagatavošanu no primārā piena parauga saskan̄ā ar standarta LVS EN ISO 6887-5:2011 "Pārtikas un dzīvnieku barības mikrobiolog̣ija. Testēšanas paraugu, sākotnējās suspensijas un decimālšḳ̄ịumu sagatavošana mikrobioloǵiskām pārbaudēm. 5. daḷa: Īpaši noteikumi piena un piena izstrādājumu sagatavošanai (ISO 6887-5:2010)" prasībām.

No primārajiem atšķaidījumiem $\left(10^{-1}\right)$, kas iegūti $1 \mathrm{~mL}$ piena parauga daudzuma sajaucot ar 9-kārtīgu sāls - peptona šḳīuma (Maximum recovery dilutent, Oxoid, Lielbritānija) daudzumu un, atkārtojot šo darbību ar katru atšķaidījumu, mēs ieguvām decimālo atšķaidījumu sēriju no $10^{-2} \mathrm{lī} d z 10^{-5}$, kas nepieciešama sēšanai uz barotnēm. Attiecīgie atšķaidījumi, tāpat arī primārais paraugs (neatšķaidīts piens), tika uznesti uz sekojošām barotnēm:

1) pētījuma 1. etapā - uz asins agara (Blood agar base, Oxoid, Lielbritānija, kam pievienotas sterilas govju asinis $50 \mathrm{~g} \mathrm{~L}^{-1}$ ), Baird Parker agara (Baird Parker agar with egg yolk supplement, Biolife Italiana, Itālija), kristālvioletā - neitrālsarkanā - žults - glikozes agara (VRBG, Violet Red Bile Glucose agar, Oxoid, Lielbritānija) un piena agara (Milk agar, Oxoid, Lielbritānija).

2) pētījuma 3. etapā - uz asins agara, Baird Parker agara, VRBG, Triptona žults glikurona jeb TBX agara (Tryptone Bile X-glucuronide medium, Oxoid, Lielbritānija) un de Man, Rogosa, Sharpe agara (MRS, Oxoid, Lielbritānija).

Kopējā mikroorganismu skaita noteikšanai piena paraugos, kurus ieguvām pētîjuma pirmajā etapā no biologiskajām saimniecībām, izmantojām piena agaru (Oxoid, Lielbritānija) saskaņā ar standarta LVS 179:1999 "Piens un piena produkti - Mikroorganismu koloniju veidojošo vienību skaita noteikšana Koloniju skaitīšanas tehnika pie $30^{\circ} \mathrm{C}$ " prasībām.

Koagulāzes pozitīvo un negatīvo stafilokoku skaitu mēs noteicām saskaņā ar standarta LVS EN ISO 6888-1: 1999/A1:2003 "Pārtikas un dzīinnieku barības mikrobiologija. Horizontālā metode koagulāzes pozitīvo stafilokoku skaitīšanai (Staphylococcus aureus un citu baktēriju veidu. 1.daḷa: Metode, lietojot Baird-Parker agara vidi. 1. labojums: Ietverot datu precizitāti" prasībām. S. aureus identifikāciju mēs apstiprinājām ar diagnostisko reaǵentu "Staphytect Plus" (Oxoid, Lielbritānija), kur pozitīva reakcija (apstiprināts S. aureus), saskaņā ar ražotāja norādēm, izpaužas kā makroskopiski redzamu pārslu veidošanās. Daļai no izolētajiem koagulāzes negatīvajiem stafilokokiem tika veikta identifikācija līdz sugas līmenim, pielietojot identifikācijas sistēmas "BBL 
Crystal Gram-positive ID” (Becton, Dickinson and Company, ASV) un "MALDI Biotyper" (Bruker, Vācija).

Enterobacteriaceae dzimtas mikroorganismu skaita noteikšanu mēs veicām saskan̄ā ar standarta LVS ISO 21528-2:2007 "Pārtikas un dzīvnieku barības mikrobiolog̣ija. Horizontālās metodes Enterobacteriaceae noteikšanai un uzskaitei. 2. daḷa: Koloniju skaitīšanas metode" prasībām, pielietojot kristālvioletā - neitrālsarkanā - žults - glikozes agaru (VRBG, Oxoid, Lielbritānija). E. coli mikroorganismu noteikšanu mēs veicām saskaņā ar Leininger un līdzautoru aprakstìto metodi (Leininger et al., 2001), bet sākotnējai E. coli izolēšanai no paraugiem MacConkey agara vietā mēs izmantojām hromogēno Triptona žults glikurona jeb TBX agaru, (Tryptone Bile Xglucuronide medium, Oxoid, Lielbritānija).

Streptokoku izolēšanu veicām saskaņā ar mikrobiologisko izmeklējumu standartu streptokoku, enterokoku un morfologiski līdzīgu organismu identifikācijai (UK Standards..., 2014) uz asins agara, kura sastāvā ir 5\% govju asinis. Pēc $24 \mathrm{~h}$ inkubācijas $37{ }^{\circ} \mathrm{C}$ temperatūrā saskaitījām streptokokiem raksturīgās kolonijas un apstiprināšanai izmantojām žults eskulīna agaru (Bile aesculine agar, Oxoid, Lielbritānija) un katalāzes testu. Visas kultūras, kas bija katalāzes negatīvas un uz žults eskulīna agara barotnes veidoja melnu vai dzeltenbrūnu krāsojumu, tika apstiprinātas par D grupas streptokokiem Enterococcus spp. Tām kultūrām, kuras nepiederēja Enterococcus spp., bet bija katalāzes negatīvas un uz asins agara radīja beta-hemolīzi, tika veikts lateksa aglutinācijas tests "PathoDxtra Strep Grouping Kit", kas paredzēts Lencfilda grupas (A, B, C, D, F, G) Streptococcus spp. identifikācijai pēc ražotāja instrukcijas (Oxoid, Lielbritānija).

Pienskābes baktēriju (Lactobacillus spp.) noteikšanu mēs veicām, pielietojot de Man, Rogosa, Sharpe agaru (MRS, Oxoid, Lielbritānija) saskaņā ar autoru aprakstīto metodi (Leininger et al., 2001). Minētā metode ir balstīta uz standarta ISO 15214:1998 "Pārtikas un dzīvnieku barības mikrobiologija Horizontālā metode mezofilo pienskābes baktēriju noteikšana - Koloniju skaitīšanas metode pie $30^{\circ} \mathrm{C}$ " prasībām.

Neskaidru situāciju gadījumā baktēriju kultūras, kuras ieguvām no piena paraugiem, identificējām, pielietojot BBL Crystal testu (Becton, Dickinson and Company, ASV) - Gram-pozitīvo un Gram-negatīvo baktēriju identifikācijas sistēmu, kurā iekḷauti vairāku substrātu fermentācijas, oksidācijas un hidrolīzes testi, bet identifikācija notiek, salīdzinot iegūtos rezultātus ar datu bāzē esošajiem.

\section{Datu statistiskā apstrāde}

Datu ieguve par somatisko šūnu skaitu govīm pētījuma pirmajā etapā veikta no Latvijas Lauksaimniecības datu centra reǵistra, bet 3. un 4. etapā SS̆S noteicām mūsu iegūtajos piena paraugos. Datu analīzē izmantota tesmeña ceturkšņu kategorizēšana šādās grupās: normāla sekrēcija, sekrēcijas traucējumi, 
latenta infekcija un mastīts saskaņā ar Starptautiskās piensaimnieku federācijas vadlīnijām (International Dairy Federation [IDF]), un šajā gadījumā robežvērtība ir 200 tūkst. šūnu $\mathrm{mL}^{-1}$ govs koppienā (Pyorala, 2003).

Savukārt, lai analizētu govs piena atbilstību pārtikas kvalitātes prasībām, kuras nosaka Eiropas Parlamenta un Padomes Regula (EK) Nr. 853/2004 (2004. gada 29. aprīlis), ar ko nosaka īpašus higiēnas noteikumus attiecībā uz dzīvnieku izcelsmes pārtiku, mēs pielietojām SŠS robežvērtību 400 tūkst. šūnu $\mathrm{mL}^{-1}$ un kopējā baktēriju skaita robežvērtību 100 tūkst. šūnu $\mathrm{mL}^{-1}$ govs koppienā.

Par pamatu pieḷaujamām fizioloǵiskajām asins morfologísko rādītāju vērtībām izmantoti publicētie dati (Wood, Quiroz-Roch, 2010).

Rezultāti tika izteikti kā vidējais aritmētiskais \pm standartkḷūda, kas raksturo vidējā rādītāja reprezentabilitāti. Lai salīdzinātu pētījumā iekḷauto govju rādītājus pirmajā un atkārtotajās izmeklēšanas reizēs, lietots Vilkoksona rangu zìmju tests (angl., Wilcoxon Signed Ranks test) divu savstarpēji saistītu paraugkopu analīzei. Savukārt, lai salīdzinātu izmeklējumu rezultātus divām savstarpēji neatkarīgām paraugkopām (GLP 810 pētījuma grupa un kontroles grupa), lietots Manna-Vitneja U (angl., Mann-Whitney $U$ ) tests.

Izmantojām arī Hī kvadrāta testu (Chi-Square test), lai novērtētu atškirību līmeni starp divām kvalitatīvām (gadalaiks, piena sekrēcijas stāvoklis, laktācija, ierosinātājs u.c.) vai semikvantitatīvām pazīmēm (ganāmpulka lielums, baktēriju skaits un somatisko šūnu skaits, sadalīts pa grupām u.c.). Krāmera V koeficienta aprēķins (angl., Cramers's V tests) deva mums iespēju novērtēt sakarības spēku un būtiskumu starp divām pazīmēm, kuras neatbilst normālam sadalījumam vai starp divām pazīmēm, kuras tika mērītas ar kārtas skalu. Savukārt ordinālās skalas datiem pielietojām Kendala (angl., Kendall's tau-b) korelācijas koeficientu (Arhipova, Bāliṇa, 2003; Paura, Arhipova, 2002).

Iekaisuma citokīnu, antibakteriālā peptīda ekspresijas un apoptozes procesa novērtēšanai lietojām pozitīvo struktūru relatīvā daudzuma puskvantitatīvo skaitīšanas metodi (Pilmane et al., 1998), kad pozitīvās struktūras tika iedalītas vairākās grupās: $(-)$ - negatīvie, $(+)$ - maz, $(++)$ - vidēji daudz un $(+++)$ daudz pozitīvās struktūras. Iegūto rezultātu izplatības salīdzinājumam lietots relatīvā biežuma aprēkina modelis (frequencies) (Goša, 2003).

Statistiskās ticamības robežvērtību visās analīzēs izmantojām $\mathrm{P}=0.95$, kas nozīmē, ka sakarība ir statistiski būtiska, ja $p<0.05$. Statistiski augsta ticamība ir tad, ja $p<0.001$ vai mazāks.

Attēlus izveidojām ar Microsoft Excel 2013 vizualizācijas programmu. 


\section{PĒTĪJUMA REZULTĀTI UN DISKUSIJA}

\section{Mikroorganismu klātbūtne govs pienā bioloğiskajos piena ražošanas ganāmpulkos Latvijā}

Mikroorganismi pienā ir daudzpusīgi pētīts temats. Zinātnieki ir nonākuši pie secinājuma, ka piens satur plašu mikroorganismu spektru (Rainard, 2017), tajā skaitā pienskābes baktērijas, sviestskābes baktērijas, pūšanas baktērijas, koliformas, raugus un pelējumsēnes, kā arī patogēnās un nosacīti patogēnās baktērijas.

Mūsu pētījuma pirmais uzdevums bija izpētīt govs piena bakteriālo daudzveidību bioloǵiskās lauksaimniecības ganāmpulkos Latvijā un to sezonālo dinamiku. Pētījumā pirmajā etapā analizējām govju piena mikrobioloǵisko piesārņojumu 14 bioloǵiskās lauksaimniecības ganāmpulkos Latvijā, bet somatiskā šūnu skaita (SŠS) dinamiku apsekoto govju pienā vērtējām, izmantojot ikmēneša pārraudzības datus.

\subsection{Kopējais baktēriju skaits}

Baktērijas, kuras pienā atrodas lielā skaitā un daudzveidībā, veido produkta dabīgo mikrobiotu (Rainard, 2017), un saistošā likumdošana (EK 853/2004) nosaka, ka līdz 100 tūkst. kvv mL ${ }^{-1}$ svaigpienā ir kvalitatīvam un drošam pienam atbilstošs daudzums. Ja kopējais baktēriju skaits (KBS) ir lielāks, tad vairumā gadījumu tas ir nepietiekamas sanitāri higiēnisko noteikumu ievērošanas dēl, bet dažkārt arī liecina par intramammāru infekciju - mastītu (Murphy, Boor, 2000).

Kopējā baktēriju skaita variācijas pienā var būt ḷoti plašas. Mūsu izpētītajā pienā KBS vidēji bija $43 \pm 5$ tūkst. $\mathrm{kvv} \mathrm{mL}^{-1}$. Autori Torkar un Teger (2008) izpētījuši, ka prasībām neatbilstoši ir $23.6 \%$ piena, un KBS tajā - apmēram 40 tūkst. kvv mL ${ }^{-1}$, un šie novērojumi ir līdzīgi mūsu veiktajiem.

Mēs izpētījām, ka bioloǵiskajās saimniecībās $84.2 \%$ piena paraugos KBS bija zems jeb atbilstošs piena kvalitātes prasībām (līdz 100 tūkst. kvv mL ${ }^{-1}$ ), bet 15.8\% paraugos KBS bija augsts (vairāk nekā 100 tūkst. kvv mL ${ }^{-1}$ ). Līdzīgā pētījumā par piena kvalitāti biologískajā piensaimniecībā Latvijā secināts, ka kopējā baktēriju skaita prasībām neatbilstošais piens sastādīja 27\% (Zagorska, 2007).

Literatūrā ir maz ziṇu par to, kā ganāmpulka lielums tiešā veidā varētu ietekmēt mikroorganismu izplatību pienā, taču ir pierādīts, ka ganāmpulka lielumam ir ietekme uz kopējo mikrobiālo piesārn,ojumu pienā, visdrīzāk, atškirīgā menedžmenta dēḷ (Jayarao et al., 2004; Cempirkova, 2006; Coorevits et al., 2008; Archera et al., 2013).

Ar̄i mēs konstatējām, ka starp ganāmpulka lielumu un baktēriju skaitu pienā pastāv būtiska sakarība (1. att.). Vislielāko baktēriju klātbūtni pienā mēs 
novērojām lielajos ganāmpulkos (C), kur KBS vidēji bija 179.8 \pm 34.8 tūkst. kvv mL ${ }^{-1}$. Mazāks KBS bija mazajos (A) ganāmpulkos, t.i., vidēji $47.7 \pm 12.2$ tūkst. $\mathrm{kvv} \mathrm{mL}^{-1}$, bet vismazāko baktēriju skaitu konstatējām vidēja lieluma (B) ganāmpulkos, t.i., vidēji 31.0 \pm 5.0 tūkst. kvv mL ${ }^{-1}$.

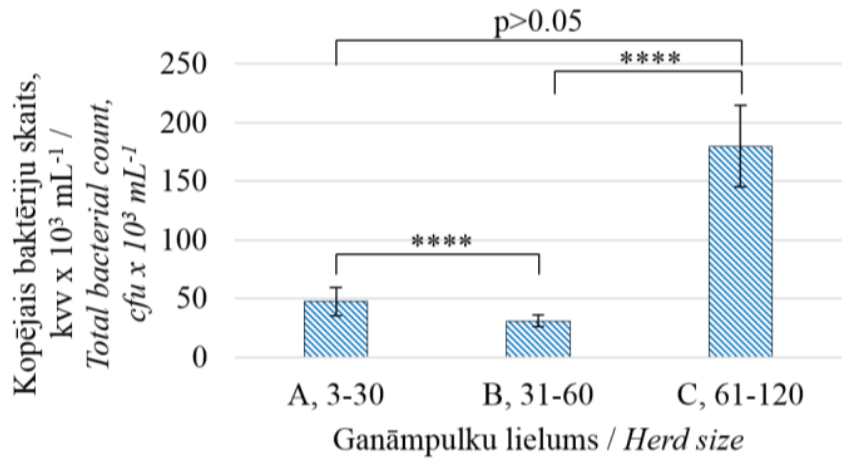

$* * * * p=0.000$

1. att. Kopējais baktēriju skaits pienā dažādu lielumu ganāmpulkos / Fig. 1. Total bacterial count in milk in association with herd size

Kvalitātes prasībām neatbilstošus paraugus, t.i., kad pienā KBS bija vairāk nekā 100 tūkst. kvv $\mathrm{mL}^{-1}$, visbiežāk mēs konstatējām lielajos (C) ganāmpulkos (23.8\%), bet pārējos ganāmpulkos retāk - A ganāmpulku grupā $12.8 \%$ un $\mathrm{B}$ ganāmpulku grupā $-8.2 \%$ izmeklēto piena paraugu.

Literatūrā plaši sastopams ir viedoklis, ka sezonālās klimata svārstības būtiski ietekmē piena mikrobiologisko sastāvu (Osteras et al., 2006; Olde Riekerink et al., 2007; Nobrega, Langoni, 2011; Zucali et al., 2011). Lai izvērtētu piena bakterioloǵiskā piesārņojuma izmaiṇas atkarībā no gadalaika, mēs analizējām ziemā, pavasarī, vasarā un rudenī iegūtos rezultātus.

Noskaidrojām, ka, atkarībā no piena paraugu ņemšanas gadalaika būtiski izmainījās KBS, bet nosacīti patogēno baktēriju prevalencei ar gadalaiku bija nenozīmīga saikne, izņemot koagulāzes negatīvos stafilokokus (KNS), jo rudenī šīs baktērijas tika konstatētas biežāk (54.3\% paraugos) nekā pārējos gadalaikos (17.0\%-32.1\% paraugos).

Kā redzams 2. att., vislielākais vidējais KBS bija ruden̄i iegūtajos paraugos $\left(243 \pm 644\right.$ tūkst. $\left.\mathrm{kvV} \mathrm{mL}^{-1}\right)$, bet pārējos gadalaikos piena bakteriālais piesārn,ojums bija būtiski zemāks (ziemā $72 \pm 11$ tūkst., pavasarī $57 \pm 16$ tūkst. un vasarā $-24 \pm 11$ tūkst. $\left.\mathrm{kvv} \mathrm{mL}^{-1}\right)(p=0.000)$. 


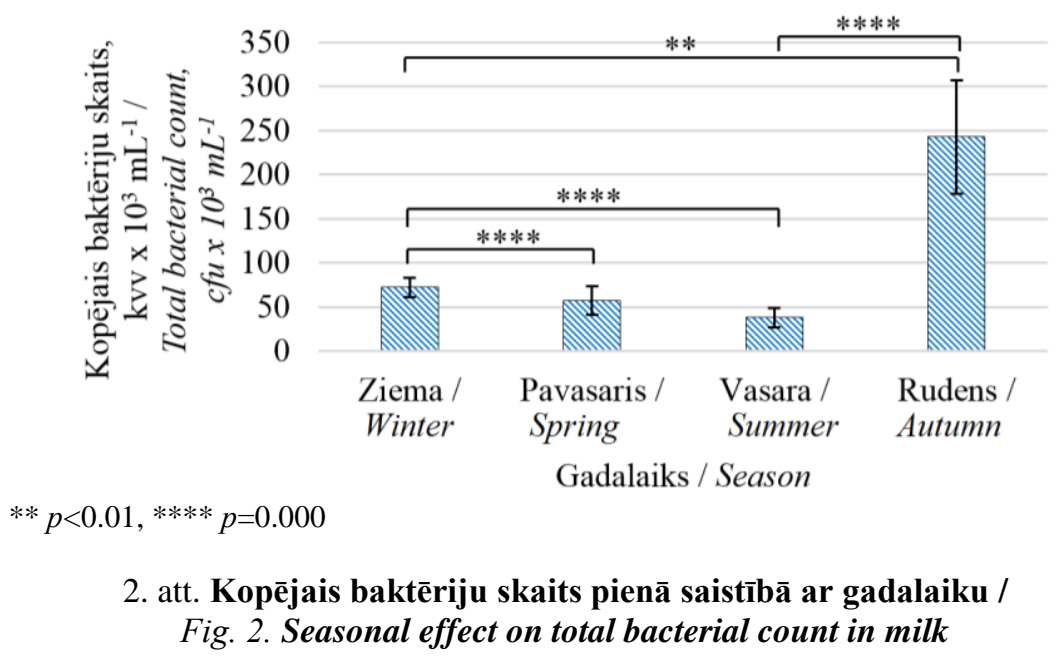

Konstatējām arī, ka ruden̄̄ un ziemā bija vislielākais skaits kvalitātes prasībām neatbilstošo paraugu (kur KBS pārsniedza 100 tūkst. $\mathrm{kvv} \mathrm{mL} \mathrm{m}^{-1}$ ), attiecīgi $21.0 \%$ un $20.6 \%$ (pavasarī un vasarā neatbilstošo paraugu skaits sastādīja attiecīgi $11.9 \%$ un $8.3 \%$ ).

Elmoslemany ar autoru kolektīvu (2010) ir izteicis pieņēmumu, ka sezonālās izmainas piena mikrobiologiskajā piesārṇojumā rada ne tikai gaisa temperatūra un nokrišņu daudzums, bet arī ganāmpulka menedžmenta īpatnības, kas ietver sanitāri higiēnisko situāciju novietnē un ganībās. Iespējams, ka lielais piesārņojums ar baktērijām ziemā un ruden̄̄ analizētajos paraugos mūsu apsekotajās saimniecībās bija saistīts ar sanitāri higiēniskās situācijas pasliktināšanos novietnē un ganībās sakarā ar kūtstāves periodu un nepietiekamu higiēnu govju stāvvietās, kā arī, ruden̄i valdošā mitruma dẹḷ.

\subsection{Piena paraugos izolētās baktērijas}

No pārtikas drošības un kvalitātes viedokḷa baktēriju klātbūtne pienā izraisa trīs nozīmīgas problēmas: mikrobiālo toksīnu klātbūtni, biofilmu veidošanos un nevēlamu fermentu klātbūtni pienā (Pukančikova et al., 2016). Turklāt, daudzas no baktērijām, kuras atrodamas veselos govju piena dziedzeros, noteiktos apstākḷıs spēj ierosināt tām mastītu. Mūsu pētījuma otrais uzdevums bija noskaidrot prevalējošos subklīniskā mastīta ierosinātājus.

No pētījuma laikā 540 izmeklētajiem piena paraugiem, prevalējošie mikroorganismi bija KNS $30.9 \%$ paraugos, S. aureus $25.2 \%$ paraugos, Enterobacteriaceae dzimtas mikroorganismi $13.7 \%$ un K. kristinae $13.1 \%$ paraugos. Retāk izolējām Micrococcus spp. (7.0\% paraugos), Corynebacterium spp. (5.4\% paraugos), Streptococcus spp. (4.6\%) un 
Bacillus spp. - $4.3 \%$ paraugos. Citus mikroorganismus izolējām $11.9 \%$ paraugos, bet $5.6 \%$ paraugos baktēriju augums kultivēšanas laikā neizveidojās.

Ir zināms, ka ierosinātāju veidam/sugai ir nozīmīga ietekme uz kopējo baktēriju skaitu un somatisko šūnu skaitu pienā. Daudzi autori ir atraduši būtisku sakarību starp SŠS un tesmeņa veselību, kur SŠS, kas lielāks par 200 tūkst. šūnām $\mathrm{mL}^{-1}$ liecina par sekrēcijas traucējumiem vai mastītu (Dohoo, Leslie, 1991; Schepers et al, 1997; Moretti et al., 1998). Kā zināms, galvenie ierosinātāji (t.sk. S.aureus, Str. agalactiae un koliformas) izraisa būtiski lielāku somatisko šūnu skaita pieaugumu nekā maznozīmīgie mastīta ierosinātāji (piem., Corynebacterium bovis un KNS) (Souza et al., 2016; Kocina, 2011; Oikonomou et al., 2014). Atbilstoši Eiropas Parlamenta un Padomes Regulas Nr. 853/2004 III pielikuma IX sadaḷas I nodaḷas III daḷas 3. punktā noteiktajiem kritērijiem, pieḷaujamais somatisko šūnu skaits svaigpienā ir līdz 400 tūkst. kvv mL ${ }^{-1}$.

Mēs konstatējām (skat. 3. att.), ka viskrasāko SŠS palielināšanos pienā izsauca S. aureus $\left(739 \pm 96\right.$ tūkst. $\left.\mathrm{mL}^{-1}\right)$, Corynebacterium spp. $\left(1059 \pm 464\right.$ tūkst. $\left.\mathrm{mL}^{-1}\right)$ un $S$. aureus asociācijā ar Enterobacteriaceae dzimtas baktērijām $\left(1607 \pm 405\right.$ tūkst. $\left.\mathrm{mL}^{-1}\right)$.

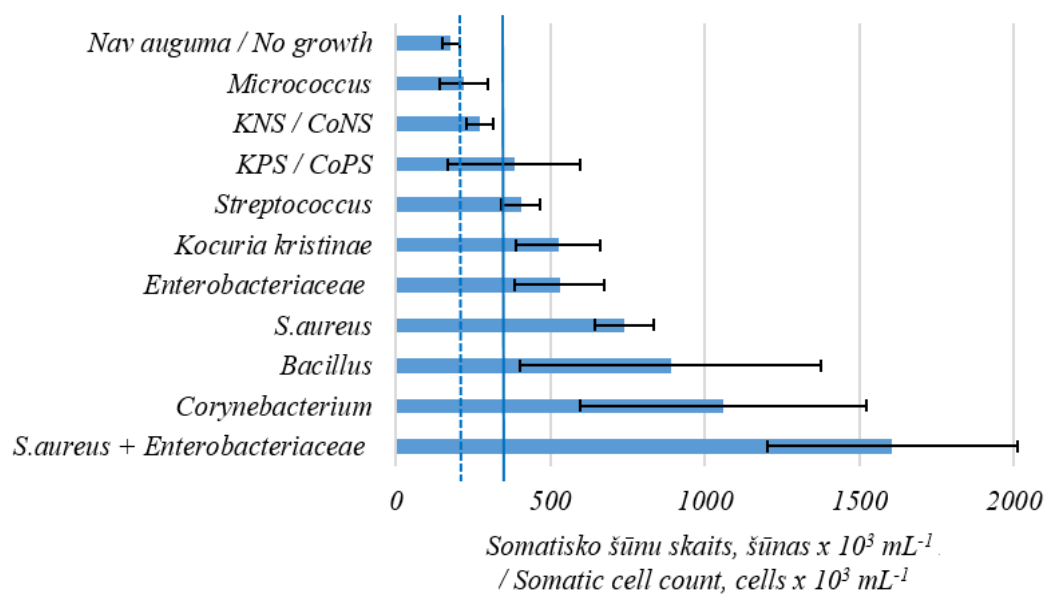

augstākā pieḷaujamā robeža kvalitatīvā svaigpienā / the highest permissible value for hygienic raw milk; - -- augstākā pieḷaujamā robeža veselā piena dziedzerī / the highest permissible value for healthy mammary gland; KNS / CoNS - koagulāzes negatīvie stafilokoki / coagulase negative staphylococci; KPS / CoPS - koagulāzes pozitīvie stafilokoki / coagulase positive staphylococci

\section{3. att. Somatisko šūnu skaits pienā saistībā ar izolētajiem mikroorganismiem /}

Fig. 3. The association between somatic cell count and isolated microorganisms 
Bet piena paraugos ar Micrococcus spp. un negatīvu bakteriologiju SŠS vidēji nepārsniedza 200 tūkst. $\mathrm{mL}^{-1}$, kas atbilst veselam piena dziedzerim.

Daudzi pētnieki ir pārliecinājušies, ka svaigpiena mikrobiologiiskā piesārņojuma līmeni ietekmē govju veselība un tīrība, apkārtējās vides tīrība, kurā govis tiek turētas un slauktas, arī tesmeņu sagatavošanas paņēmiens pirms slaukšanas, slaukšanas tehnika, slaukšanas aparatūras un piena cisternu tīrǐšanas un dezinfekcijas metodes, atdzesēšanas ātrums un piena uzglabāšanas laiks (Oleggini et al., 2001; Jayarao et al., 2004; Cempirkova, 2006; Coorevits et al., 2008; Vacheyrou et al., 2011; Mallet et al., 2012). Vienā vārdā visus šos nozīmīgos faktorus var dēvēt par ganāmpulka un slaukšanas menedžmentu.

Mūsu iegūtie rezultāti par mikroorganismiem pienā liek domāt, ka Latvijā biologiskajās piensaimniecībās slaucamo govju ganāmpulka un slaukšanas menedžmentu veiksmīgāk īsteno saimniecības, kurās ir no 31 līdz 60 govīm novietnē, tātad vidēji lielas saimniecības, par ko liecina: (1) vismazākais kopējais baktēriju skaits (vidēji $31.0 \pm 5.0$ tūkst. $\mathrm{kvv} \mathrm{mL}^{-1}$ ), (2) mazs mikrobioloğiskās kvalitātes prasībām neatbilstošo paraugu skaits $(8.2 \%)$, (3) būtiski mazāks vidējais somatisko šūnu skaits ( $349 \pm 48$ tūkst. $\left.\mathrm{mL}^{-1}\right)$ nekā mazajos un lielajos ganāmpulkos, (4) kā arī būtiski mazāka koliformu baktēriju izplatība (11.1\%) nekā lielo ganāmpulku pienā.

\section{Imūnmodulatoru komponentu un kompozīciju antibakteriālās aktivitātes izvērtēšana in vitro apstākḷos}

Viena no perspektīvām pieejām infekcijas slimību ārstēšanā ir imūnmodulācija. Dzīvnieku veselības kontekstā imūnmodulācija tiek definēta kā spēja uzlabot dzīvnieka rezistenci pret infekcioziem aǵentiem un stresa faktoriem ar nolūku veicināt dzīvnieku produktivitāti. Savukārt vielas, kuras tiek pielietotas imūnmodulācijā, tiek sauktas par imūnmodulatoriem (Dhama et al., 2015).

Govs piens satur daudzas imunologiski aktīvas vielas ar antibakteriālu aktivitāti, bet vienas no svarīgākajām ir lizocīms un laktoferīns (Lucarini, 2017). Pēdējās pāris desmitgadēs imūnmodulatoru terapeitiskā ietekme ir pētīta plaši, un šo pētījumu rezultāti liek domāt, ka šāda veida sistēmiska organisma imūnās reaktivitātes ierosināšana varētu novērst subklīniskā mastīta attīstību klīniskajā mastîtā vai pat veicināt piena dziedzeru izveselı ošanos.

N̦emot vērā pētījuma 1. etapā iegūtos rezultātus, ka prevalējošie ierosinātāji biolog̣iskās ražošanas slaucamo govju ganāmpulkos bija koagulāzes negatīvie stafilokoki, S. aureus, Enterobacteriaceae dzimtas mikroorganismi un $K$. kristinae, un šo ierosinātāju sastopamība pienā bija saistìta ar paaugstinātu SŠS, mēs to tīrkultūras pielietojām, lai in vitro apstākḷos tālāk izvērtētu imūnmodulatoru komponentu un kompozīciju antibakteriālo aktivitāti un izvēelētos vienu kompozīciju subklīniskā mastīta ārstēšanai (skat. 1. tab.). 


\section{Komponentu antibakteriālā iedarbība uz mikroorganismiem in vitro / Antibacterial activity of componentes on mastitis pathogens in vitro}

\begin{tabular}{|c|c|c|c|c|c|c|c|c|}
\hline \multirow{3}{*}{$\begin{array}{l}\text { Imūnmodulatoru komponenti / } \\
\text { Immunomodulating components }\end{array}$} & \multicolumn{7}{|c|}{ Mikroorganismu kultūras / Pathogens } & \multirow[b]{2}{*}{ 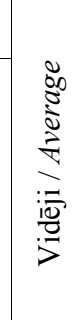 } \\
\hline & 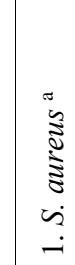 & 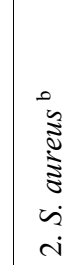 & 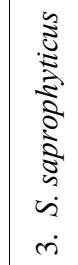 & 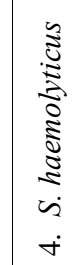 & $\begin{array}{l}\ddot{\tilde{8}} \\
\text { ix } \\
\dot{\text { in }}\end{array}$ & 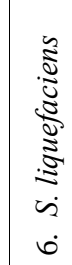 & 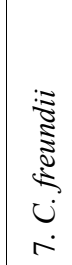 & \\
\hline & \multicolumn{8}{|c|}{$\begin{array}{l}\text { augšanas aiztures zona, } \mathrm{mm} / \text { zone of } \\
\text { growth inhibition, } \mathrm{mm}\end{array}$} \\
\hline $\begin{array}{l}\text { Lizocīms / Lyzozyme (AppliChem } \\
\text { GmbH, Vācija) }\end{array}$ & 18.5 & 19.5 & 19.5 & 18.5 & 20.0 & 18.0 & 15.0 & 18.4 \\
\hline Laktoferīns / Lactoferrin (Vācija) & 8.0 & 9.0 & 11.0 & 8.0 & 8.0 & 9.0 & 11.0 & 9.1 \\
\hline Laktoferīns / Lactoferrin (RSU MVI) & 0.0 & 10.0 & 0.0 & 10.0 & 0.0 & 0.0 & 0.0 & 2.9 \\
\hline $\begin{array}{l}\text { Pienskābe / Lactic acid (BDH } \\
\text { Prolabo, İrija) }\end{array}$ & 12.3 & - & 12.7 & 24.3 & 8.3 & 17.0 & 18.7 & 15.6 \\
\hline Kazeīns / Casein (RSU MVI) & 0.0 & 0.0 & 0.0 & 0.0 & 0.0 & 0.0 & 0.0 & 0.0 \\
\hline $\begin{array}{l}\text { Celttekas ekstrakts / Psyllium extract } \\
\text { (RSU MVI) }\end{array}$ & 0.0 & 7.0 & 0.0 & 0.0 & 0.0 & 0.0 & 0.0 & 1.0 \\
\hline $\begin{array}{l}\text { Kumelītes ekstrakts / chamomile } \\
\text { extract (RSU MVI) }\end{array}$ & 7.0 & 7.0 & 12.0 & 7.0 & 8.0 & 8.0 & 0.0 & 7.0 \\
\hline $\begin{array}{l}\text { L. helveticus glikopeptīds } \\
10^{9} \mathrm{kvv} \mathrm{g}^{-1} / \text { glycopeptide } 10^{9} \mathrm{cfu} \mathrm{g}^{-1} \\
\text { (RSU MVI) }\end{array}$ & 14.2 & 0.0 & 12.2 & 0.0 & 11.0 & 0.0 & 0.0 & 6.2 \\
\hline
\end{tabular}

${ }^{a}$ S. aureus (tipisks celms / typical strain), ${ }^{\text {b }}$ S. aureus (mazo koloniju variants / small colony variants)

Izvērtējot atsevišksu dabīgo vielu komponentu antagonistisko efektu uz mastītu ierosinātāju kultūrām, kā redzams 1. tabulā, vislielāko antibakteriālo aktivitāti in vitro uzrādīja lizocīms (15.0 līdz $19.5 \mathrm{~mm})$, pienskābe (8.3 līdz $24.3 \mathrm{~mm}$ ) un laktoferīns (8.0 līdz $11.0 \mathrm{~mm})$, kas visas ir pienskābes baktēriju izcelsmes imunoloǵiski aktīvas vielas, tāpēc šie komponenti, kurus dabīgi satur govs piens, izmantojām arī turpmāk, veidojot imūnmodulējošo kompozīciju mastīta ierobežošanai govīm.

Ir zināms, ka lizocīms, darbojoties viens pats, lizē Gram-pozitīvo baktēriju šūnu sieninuu pamatsastāvdaḷu - peptidoglikānu, izraisot šūnu bojāeju. Tieši šīs lizocīma îpašîbas dẹl ir iespējams novērot tā antibakteriālo iedarbību 
in vitro (Lawrence, Pane, 2007). Turpretī Gram-negatīvie mikroorganismi pret lizocīma destruktīvo ietekmi ir daudz izturīgāki, jo to šūnu sieniņas satur apmēram piecas reizes mazāk peptidoglikāna, bet ir aizsargātas ar lipīdu un gḷotu slāni (Lawrence, Pane, 2007). Mūsu pārbaudītajam lizocīmam antibakteriālo iedarbību novērojām līdzīgā mērā gan pret Gram-pozitīvajām (18.5-19.5 mm), gan pret Gram-negatīvajām baktērijām $(18-20 \mathrm{~mm})$, bet mazāka nomākuma zona bija Citrobacter freundii baktērijām $(15.0 \mathrm{~mm})$ (skat. 1. tab.).

Laktoferīna antibakteriālās iedarbības pamatā, pirmkārt, ir spēja saistīt dzelzi, līdz ar to padarot to nepieejamu patogēnajām baktērijām, turpretim veicinot labvēlīgo baktēriju augšanu. Otrkārt, laktoferīns izraisa Gram-negatīvo baktēriju šūnapvalku bojājumus (Kutila et al., 2003; Panwar, 2014). Mēs pārbaudījām divu veidu laktoferīnu, t.i., RSU kolēǵu no pirmpiena izdalīto laktoferīnu un no Vācijas iepirkto, rūpnieciski ražoto, laktoferīnu. No pirmpiena izdalītais laktoferīns antibakteriālo aktivitāti (10 mm nomākuma zonu) uzrādīja tikai pret divām kultūrām, un abas bija Gram-pozitīvās baktērijas, t.i., S. aureus mazo koloniju variants un S. haemolyticus. Savukārt no Vācijas iepirktais laktoferīns izrādīja vidēji lielu antagonistisko aktivitāti pret visiem pārbaudītajiem mastìta ierosinātājiem ( 8 līdz $11 \mathrm{~mm}$ diametrā) (skat. 1. tab.).

Pienskābe ir pienskābes baktēriju vielmaiņas galaprodukts, kas iznīcina daudzas patogēnās baktērijas vai vismaz nomāc to augšanu. Antibakteriālās iedarbības pamatā ir pH samazināšanās (Widyastuti et al., 2014), un mēs novērojām, kā redzams 1. tab., ka pienskābei ar neitralizētu $\mathrm{pH}$ joprojām piemīt visai augsta antagonistiskā ietekme uz visu septiņu pārbaudīto patogēno baktēriju augšanu, t.i., vidēji $15.6 \mathrm{~mm}$.

Pēdējos gados aktīvi notiek pētījumi par ārstniecības augiem, ar mērḳi noteikt to potenciālu infekcijas slimību ārstēšanā. Ir pētījumi, kuri ziņo par fitoterapeitisko zāḷu līdzekḷu lielo imūnmodulatoro potenciālu, kam pateicoties iespējams panākt efektīvu stāvokḷa uzlabošanos un pat pilnīgu izvesel̦ošanos gan klīnisko, gan subklīnisko mastītu gadījumos (Abaineh, Sintayehu, 2001; Verma, Nauriyal, 2009; Umadevi, Umakanthan, 2010).

Mēs pārbaudījām lielās celttekas (lat., Plantago major) lapu ekstraktu un ārstniecības kumelītes (lat., Matricaria recutita) ekstraktu. Ieguvām rezultātus, ka mūsu pārbaudītajam ceḷtekas ekstraktam bija zema antibakteriālā aktivitāte, kas izpaudās tikai pret vienu no mikroorganismiem - S. aureus mazo koloniju variantu. Mūsu pārbaudītajam kumelīšu ekstraktam vislielākā antagonistiskā aktivitāte bija pret $S$. saprophyticus $(12 \mathrm{~mm})$.

Turpmāk mēs pārbaudījām arī vairāku kompozīciju antibakteriālo aktivitāti (skat. 2. tab.). 
2. tabula / Table 2

Kompozīiju un kontroles preparātu antibakteriālā aktivitāte in vitro / Antibacterial activity in vitro of compositions and control preparations

\begin{tabular}{|c|c|c|c|c|c|c|c|c|}
\hline \multirow{3}{*}{$\begin{array}{l}\text { Imūnmodulatoru kompozīcijas / } \\
\text { Immunomodulating compositions }\end{array}$} & \multicolumn{7}{|c|}{ Mikroorganismu kultūras / Pathogens } & \multirow[b]{2}{*}{ 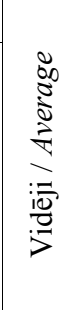 } \\
\hline & 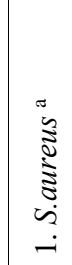 & 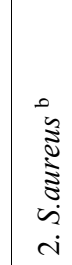 & 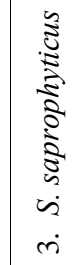 & 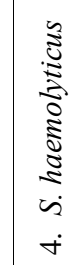 & $\begin{array}{l}\stackrel{\ddot{8}}{8} \\
\dot{i} \\
\dot{n}\end{array}$ & 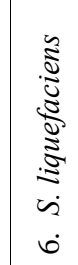 & $\frac{i}{i}$ & \\
\hline & \multicolumn{8}{|c|}{$\begin{array}{l}\text { augšanas aiztures zona, } \mathrm{mm} / \text { zone of } \\
\text { growth inhibition, } \mathrm{mm}\end{array}$} \\
\hline $\begin{array}{l}\text { Kazeīns un L. helveticus glikopeptīds } \\
10^{7} \mathrm{kvv}^{-1} / \text { Casein and } L \text {. helveticus } \\
\text { glycopeptide } 10^{7} \text { cfu } \mathrm{g}^{-1}\end{array}$ & 0.0 & 0.0 & 0.0 & 0.0 & 8.0 & 0.0 & 0.0 & 1.1 \\
\hline $\begin{array}{l}\text { Lizocīms un L. helveticus } \\
\text { glikopeptīds / Lysozyme and L. } \\
\text { helveticus glycopeptide }\end{array}$ & 9.0 & 0.0 & 0.0 & 8.0 & 0.0 & 0.0 & 0.0 & 2.4 \\
\hline $\begin{array}{l}\text { Lizocīms } 100 \mathrm{mg} \text {, laktoferīns } 100 \mathrm{mg} \text {, } \\
\text { glikopeptīds } 10 \mathrm{mg} \text {, pienskābe } 1 \mathrm{~mL} \text { / } \\
\text { Lysozyme } 100 \mathrm{mg} \text {, lactoferrin } \\
100 \mathrm{mg} \text {, glycopeptide } 10 \mathrm{mg} \text {, lactic } \\
\text { acid } 1 \mathrm{~mL}\end{array}$ & 15.5 & 15.0 & 17.0 & 15.0 & 17.0 & 15.0 & 15.0 & 15.6 \\
\hline $\begin{array}{l}\text { Lizocīms } 100 \mathrm{mg} \text {, laktoferīns } 100 \mathrm{mg} \text {, } \\
\text { glikopeptīds } 10 \mathrm{mg} \text {, pienskābe } 1 \mathrm{~mL}, \\
\text { celtekas koncentrāts } 1 \mathrm{~mL} / \text { Lysozyme } \\
100 \mathrm{mg} \text {, lactoferrin } 100 \mathrm{mg} \text {, } \\
\text { glycopeptide } 10 \mathrm{mg} \text {, lactic acid } 1 \mathrm{~mL} \\
\text { and Psyllium extract }\end{array}$ & 18.0 & 18.5 & 19.0 & 20.5 & 20.0 & 18.0 & 19.5 & 19.1 \\
\hline $\begin{array}{l}\text { Kompozīija GLP 810: glikopeptīds } \\
10 \mathrm{mg} \text {, lizocīms } 300 \mathrm{mg} \text {, pienskābe } \\
500 \mathrm{mg} / \text { Composition GLP 810: } \\
\text { glycopeptide } 10 \mathrm{mg} \text {, lysozyme } \\
300 \mathrm{mg} \text {, lactic acid } 500 \mathrm{mg}\end{array}$ & 10.0 & 15.0 & 0.0 & 0.0 & 9.0 & 0.0 & 0.0 & 4.9 \\
\hline \multicolumn{9}{|c|}{ kontroles preparāti / control preparations } \\
\hline Synulox LC & 41.3 & 46.7 & 45.3 & 24.0 & 12.0 & 22.0 & 22.3 & 30.5 \\
\hline Tetra-Delta & 50.0 & 50.0 & 33.0 & 15.0 & 25.0 & 24.0 & 26.0 & 31.9 \\
\hline Eurofit Gel & 41.0 & 49.3 & 32.0 & 24.0 & 22.0 & 23.0 & 24.0 & 30.8 \\
\hline $0.9 \% \mathrm{NaCl}$ & 0.0 & 0.0 & 0.0 & 0.0 & 0.0 & 0.0 & 0.0 & 0.0 \\
\hline
\end{tabular}

a S.aureus (tipisks celms / typical strain), ${ }^{\mathbf{b}}$ S.aureus (mazo koloniju variants / small colony variants) 
Kompozīcija, kas sastāvēja no kazeīna un glikopeptīda uzrādīja nelielu antagonistisku aktivitāti pret $E$. coli kultūru $(8.0 \mathrm{~mm})$, bet kompozīija, sastāvoša no lizocīma un glikopeptīda - pret S.aureus tipisko celmu $(9 \mathrm{~mm})$ un $S$. haemolyticus $(8 \mathrm{~mm})$.

Kompozicija, kuras sastāvā bija lizocīms, laktoferīns, pienskābe un L. helveticus glikopeptīds radīja vidēji $15.6 \mathrm{~mm}$ lielu nomākuma zonu. Vēl lielāka antibakteriālā aktivitāte tika novērota līdzīga sastāva kompozīcijai, kas papildināta ar cel̦teku koncentrātu, t.i., vidēji $19.1 \mathrm{~mm}$.

Mūsu pārbaudītā kompozīcija GLP 810, kuras sastāvā tika iekḷautas vielas ar vislielāko antibakteriālo aktivitāti, t.i., lizocīms un pienskābe, kombinācijā ar L. helveticus glikopeptīdu, uzrādīja antagonistisku iedarbību pret abu tipu $S$. aureus celmiem un arī pret $E$. coli, veidojot no 9.0 līdz $15.0 \mathrm{~mm}$ lielu auguma nomākumu, un šo kompozīciju mēs izvēlējāmies kā optimālāko variantu, lai veiktu jaunizveidotā imūnmodulatora ar antibakteriālu iedarbību pārbaudi tālāk in vivo apstākḷos.

Jebkuras vielas iedarbības pamatā ḷoti svarīga ir tās hemolītiskāa aktivitāte un sterilitāte, tāpēc mēs veicām komponentu un kompozīciju hemolītiskās aktivitātes pārbaudes. Pēc $24 \mathrm{~h}$ inkubācijas $37{ }^{\circ} \mathrm{C}$ temperatūrā neviens no mūsu pārbaudītajiem imūnmodulatoru komponentiem un kompozīcijām neradīja hemolīzi asins agarā, kā arī uz asins agara barotnes mikroorganismu augums neveidojās, līdz ar to ir pielietojamas intramammārai lietošanai.

\section{Imūnmodulatoru darbība in vivo apstākḷos}

Pētījuma 2. etapā noskaidrojām, ka vielas, kas uzrādīja vislielāko antibakteriālo aktivitāti in vitro - bija lizocīms, pienskābe un laktoferīns. Savukārt kompozīciju GLP 810, kuras sastāvā tika iekḷauts lizocīms un pienskābe, kombinācijā ar imūnmodulatoru L. helveticus, mēs izvēlējāmies kā optimālāko variantu, lai veiktu tālāk jaunizveidotā imūnmodulatora ar antibakteriālu iedarbību pārbaudi in vivo apstākḷos govīm ar subklīnisko mastītu.

\subsection{Mastīta ierosinātāji pienā}

Viena no svarīgām imūnmodulatoru īpašībām, kas ḷauj tos izmantot infekcijas slimību profilaksē un ārstēšanā, ir to antagonistiskā iedarbība pret patogēnajām baktērijām, tajā pašā laikā neradot nelabvēlīgu efektu uz dabīgo mikrobiotu (Banos et al., 2013). In vivo pētījumos ir labi pierādīta lizocīma un pienskābes antibakteriālā aktivitāte kā daḷa no nespecifiskās dabīgās imunitātes (Brul, Coote, 1999; Benkerroum, 2008; Ella et al., 2011; Espeche et al., 2012).

In vivo pētījuma laikā mēs novērojām, ka pēc GLP 810 infūzijām eksperimentālās govju grupas pienā no ierosinātājiem brīvo piena dziedzeru skaits būtiski palielinājās (no 3 uz 11) un, kā redzams 4. attēlā, būtiski 
samazinājās nosacīti patogēno baktēriju skaits (NPBS) piena paraugos par $87 \%$ (no $51 \pm 29 \quad$ līdz $7 \pm 4$ tūkst. $\mathrm{kvv} \mathrm{mL}^{-1}$ ) 3 . dienā un par $92 \%$ (līdz $4 \pm 2$ tūkst. $\left.\mathrm{kvv} \mathrm{mL}^{-1}\right)$ 7. pètījuma dienā $(p<0.01)$.

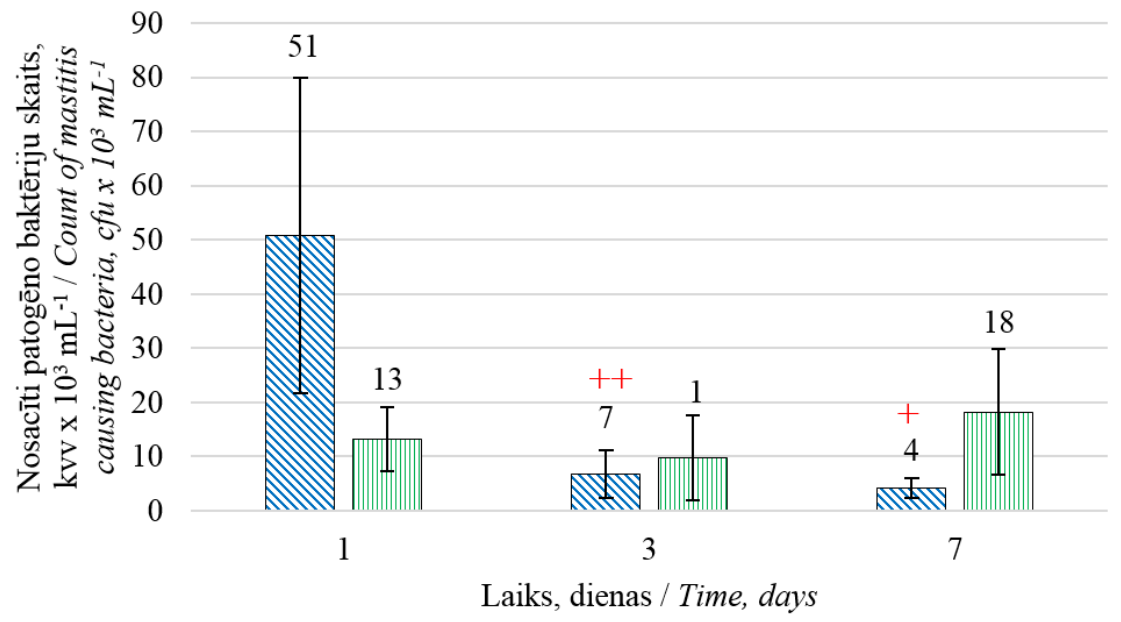

$\mathbb{\mathbb { G }}$ GLP 810, $\square$ Kontrole / Control, $+p<0.05,++p<0.01$

\section{4. att. Nosacīti patogēno baktēriju skaita dinamika / \\ Fig. 4. Dynamics of mastitis causing bacteria count}

Kopumā izmaiṇas NPBS bija statistiski nebūtiskas salīdzinot ar kontroles grupu, jo kontroles grupā, uzsākot pētījumu, NPBS, lai arī statistiski būtiski neatšķīrās, tomēr vidēji bija zemāks nekā GLP 810 pētījuma grupā, t.i., $13 \pm 6$ tūkst. $\mathrm{kvv} \mathrm{mL}^{-1}$. Tomēer noskaidrojām, ka NPBS no pētījuma 1. uz 3. dienu būtiski samazinājās (par 97\%) eksperimentālās grupas govju piena dziedzeros ar sākotnēji augstu SŠS, tātad, subklīniskā mastīta gadījumos $(p<0.05)$. GLP 810 pētījuma grupas govīm ar sākotnēji zemu SŠS pienā un kontroles grupas govīm NPBS izmainas nebija būtiskas.

Vairāki pētnieki ir veikuši probiotiku un to izdalīto aktīvo vielu pārbaudes in vivo slaucamajām govīm un ir ieguvuši līdzịgus rezultātus - pateicoties iedzimtās imūnās sistēmas stimulācijai, patogēno mikroorganismu klātbūtne tiek ierobežota (Frola et al., 2012; Cao et al., 2007; Kai et al., 2002).

Analizējot visus pētījuma 1. dienā iegūtos piena paraugus $(n=38)$, konstatējām, ka patogēno baktēriju skaitam pārsniedzot 100 tūkst. kvv mL ${ }^{-1}$, $100 \%$ gadījumos piena dziedzerī norisinājās mastīts $(p<0.01$, Kendala koef. $0.425)$. 


\subsection{Piena kvalitātes rādītāju izvērtēšana}

Lai izvērtētu imūnmodulatoru ietekmi uz piena kvalitāti, mēs analizējām gan somatisko šūnu skaita un kopējā baktēriju skaita, gan uzturvielu satura (tauku, laktozes un olbaltumvielu) daudzuma dinamiku pirms kompozīciju ievadīšanas un kompozīciju pielietošanas laikā. Noteicām arī piena paraugos pH līmeni.

Krasas izmaiṇas pēc kompozīcijas GLP 810 infūzijām mēs konstatējām somatisko šūnu skaitā, jo SŠS, kurš 1 . dienā bija $1.6 \pm 0.8$ milj. šūnu $\mathrm{mL}^{-1}, 48$ stundu laikā pēc GLP 810 1. un 3. infūzijas, t.i., pētījuma 3. un 7. dienā, bija būtiski palielinājies (attiecīgi līdz $5.8 \pm 0.6$ milj. un 3.3 milj. šūnu $\mathrm{mL}^{-1}$ ), bet 14. dienā vairs būtiski neatšḳīās no sākotnējā daudzuma pienā (skat. 5. att.).

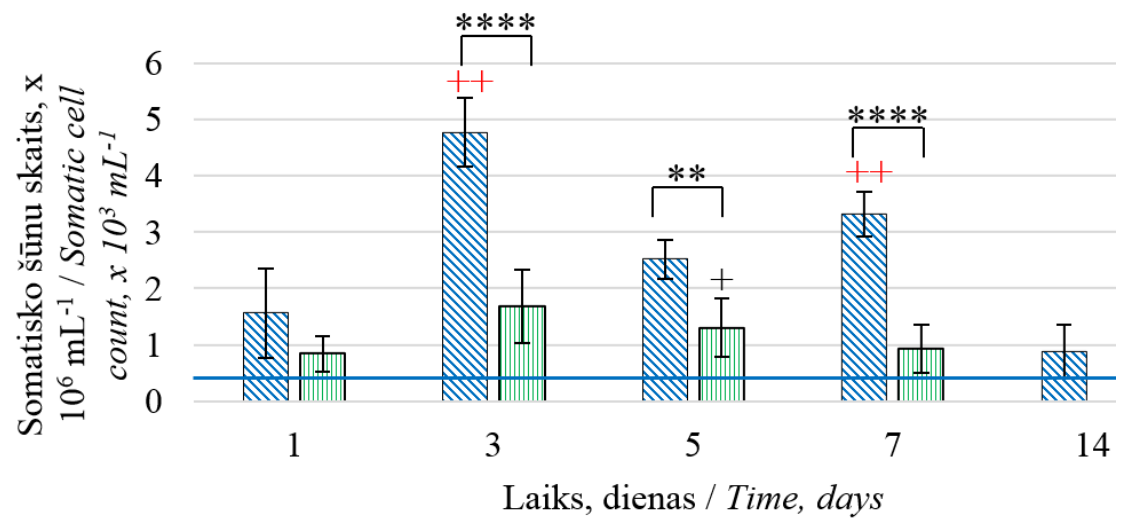

$\mathbb{\mathbb { Q }}$ GLP 810, $\square$ Kontrole / Control; $+p<0.05,++p<0.01-v s .1$. diena / vs. 1 st day; ** $p=0.01$, **** $p=0.000$ - GLP 810 vs. kontrole / GLP 810 vs. control;

L_ augstākā pielaujamā robeža kvalitatīvā svaigpienā / the highest permissible value for hygienic raw milk

\section{5. att. Somatisko šūnu skaita dinamika /}

Fig. 5. Dynamics of somatic cell count

Konstatējām, ka SŠS vidējo pieaugumu no 1. līdz 5. dienai radīja galvenokārt piena dziedzeri ar sākotnēji zemu SŠS, bet pētījuma 7. dienā SŠS palielinājās arī ceturkšņos ar subklīnisko mastītu. SŠS svārstības kontroles grupā iegūtajos piena paraugos bija statistiski nebūtiskas visu pētījuma laiku, izṇemot 5. dienā, kad SŠS bija statistiski būtiski paaugstinājies no $0.8 \pm 0.3$ milj. uz $1.3 \pm 0.5$ milj. šūnu $\mathrm{mL}^{-1}$.

Mūsu novērojumus daļeji apstiprina citu autoru iegūtie dati, ka $0.9 \% \mathrm{NaCl}$ infūzijas neizraisa būtisku SŠS palielināšanos piena dziedzerī (Wellnitz et al., 2014), bet, ievadot piena dziedzeros vielas ar imūnmodulējošām 
īpašībām, piemēram, TNF (Watanabe et al., 2000), rekombinanto liellopu CD14 proteīnu (Erskine et al., 2004) un laktoferīnu (Kai et al., 2002), ir novērots somatisko šūnu skaita straujš pieaugums.

Autori (Watanabe et al., 2000; Stefanov, Petrovski, 2006; Ogola et al., 2007; Alnakip et al., 2014) raksta, ka augsto SŠS pienā rada galvenokārt neitrofîlo leikocītu imigrācija piena dziedzera audos. Aktivizēti neitrofîlie leikocīti veic ne vien patogēno baktēriju fagocitozi, bet arī izdala nespecifiskas baktericīdas vielas, kā rezultātā var samazināties piena sintēze un galveno specifisko piena sastāvdaļu daudzums, kā arī paaugstināties piena enzimātiskā aktivitāte, kas iedarbojas uz piena olbaltumvielām un taukiem destruktīvi.

Tomēr mūsu novērojumi neapstiprināja ne izslaukuma, ne piena sastāvdaḷu daudzuma samazināšanos pēc veiktajām preparātu infūzijām, izṇemot laktozes daudzumu, kurš GLP 810 pētījuma grupas govju pienā būtiski samazinājās no $4.7 \%$ 1. dienā līdz 4.1\% 3. dienā, bet 7. dienā laktozes līmenis joprojām bija būtiski $(p<0.001)$ samazināts, t.i., $4.2 \%$ (skat. 6. att.).
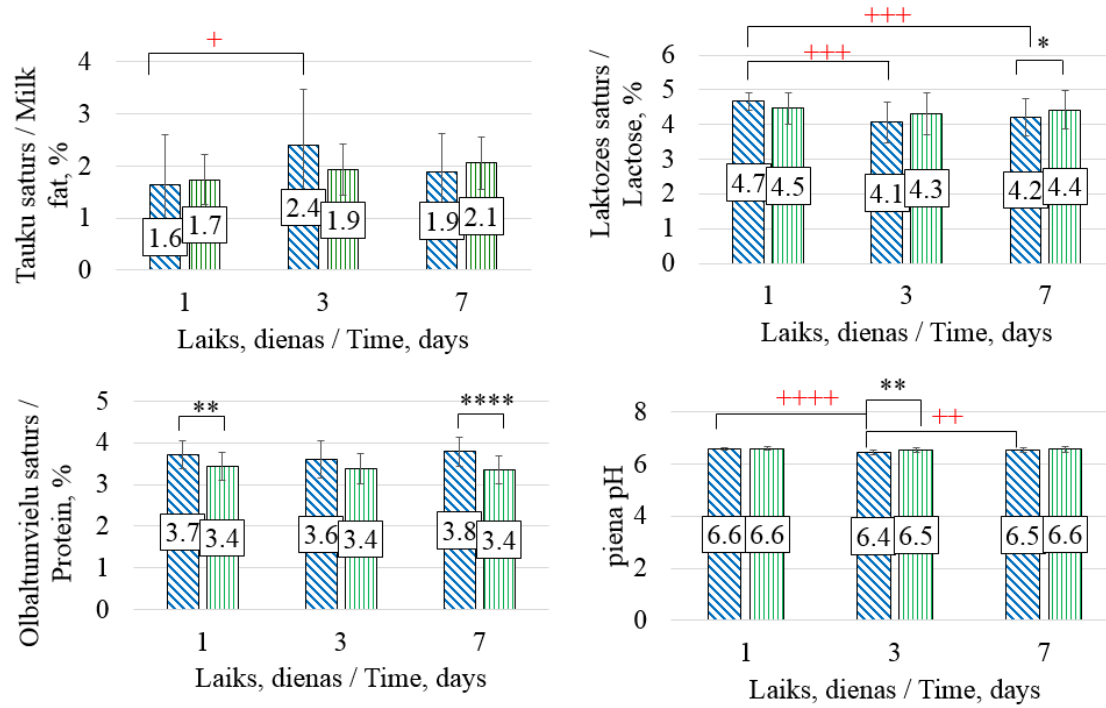

$\mathbb{Q}$ GLP 810, $\square$ Kontrole / Control; $+p<0.05,++p<0.01,+++p<0.001,++++p=0.000$; $* p<0.05, * * p=0.01, * * * * p=0.000-$ GLP 810 vs. kontrole / GLP 810 vs. control

\section{6. att. Tauku, laktozes, olbaltumvielu saturs pienā un piena pH / Fig. 6. Milk fat, lactose, protein and pH dynamics in milk}

Olbaltumvielu daudzums pienā pēc preparātu infūzijām būtiski neizmainījās (eksperimentālās grupas govju pienā tas bija 3.7-3.8\% un būtiski zemāks - kontroles paraugos, t.i., 3.4\%). Tauku saturs eksperimentālajā grupā 
iegūtajos paraugos 3. dienā bija būtiski paaugstinājies (no 1.6\% līidz 2.4\%), bet kontroles grupā bez būtiskām izmaināam (1.7-2.1\%) (skat. 6. att.).

Ṇemot vērā, ka kompozīcijas GLP 810 infūzijas neizraisīja destruktīvu ietekmi uz uzturvielām pienā, secinām, ka neitrofīlo leikocītu infiltrācija piena dziedzera audos ir noritējusi ar kontrolētu intensitāti.

\subsection{Govju veselības stāvoklis un piena vizuālās pārmaiṇas}

Pētījuma laikā konstatējām, ka govju klīniskais stāvoklis nepasliktinās (ķermeņa temperatūra, izslaukums, apetīte), kā arī piena dziedzeru klīniskais stāvoklis bija bez patoloǵiskām izmaiņām. Tomēr pēc preparātu infūziju uzsākšanas abu pētāmo grupu pienā dažkārt tika novērotas vizuālas izmaiņas piena konsistencē (pārslu vai nedaudzu recekḷu klātbūtne pienā), kas būtiski vairāk bija GLP 810 pêtījuma grupas govīm no 3. līdz 6. dienai.

Mēs konstatējām, ka pārslu un recekḷu veidošanos būtiski ietekmēja piena $\mathrm{pH}(p<0.005)$, jo tie tika novēroti tikai govīm, kuru piena paraugos $\mathrm{pH}$ bija robežās no 6.40-6.52, tātad zemāks nekā vidēji grupā. Turklāt šīs piena konsistences izmaiņas, iespējams, bija saistītas ar paaugstinātu leikocītu aktivitāti pienā, jo recekḷus un pārslas novērojām gandrīz tikai tajos piena paraugos (19 no 20), kuros SŠS pārsniedza 200 tūkst. $\mathrm{mL}^{-1}(p=0.000)$.

Recekḷi pienā parasti ir kazeīna micellārās struktūras degradācijas rezultāts. Autori ziņo, ka kazeīns savu stabilitāti zaudē, ja piena pH ir pH 4.6 un zemāks (Guo, Wang, 2016). Tomēr mūsu iegūtie rezultāti neapstiprina šādu iespēju, jo pH nevienā no analizētajiem piena paraugiem nebija zemāks nekā 6.2, turklāt olbaltumvielu saturs pienā pētījuma laikā būtiski nemainījās. Iespējams, ka recekḷu un pārslu veidošanos pēc kompozīcijas GLP 810 ievadīšanas tesmeņos izraisījušas somatisko šūnu izdalītās proteāzes, kas spēj izraisīt beta kazeīna hidrolīzi un sekojošu proteolīzi (Li et al., 2014). Tādā gadījumā tomēr proteāžu aktivitāte piena dziedzeros pētījuma laikā ir bijusi zema, jo to novērojām fokāli.

\subsection{Leikocītu dinamika pienā un asinīs}

Leikocīti ir imūnsistēmas šūnas, kas veic daudzveidīgas funkcijas, un tos iedala granulocìtos (jeb polimorfonukleārajos leikocītos, PMNL) un agranulocìtos (limfocīti un monocīti/makrofăgi). Daļa leikocìtu piena dziedzerī ir pastāvīgi klātesoši, tie veicina tesmeņa audu atjaunošanos involūcijas laikā un pēc iekaisumiem, kā arī nodrošina tūlītēju imūno aizsardzību infekciozo ierosinātāju invāzijas gadījumā (Alnakip et al., 2014).

Lai izvērtêtu imūnmodulatoru kompozīcijas GLP 810 ietekmi uz govju imūnās sistēmas funkcionālo stāvokli govju perifērajā asinsritē un lokāli piena dziedzeros, mēs noteicām leikocītu skaitu, leikocītu populācijas un limfocìtu subpopulāciju virsmas CD marķierus, kā arī analizējām leikocītu savstarpējo dinamiku starp perifēro asinsiti un piena dziedzeriem. 
PMNL ir pirmās šūnas, kuras, infekcijai sākoties, no asinsrites ieplūst piena dziedzera audos. PMNL migrācija izsauc mastìtam raksturīgo paaugstināto SŠS pienā, un tās mērḳis ir veikt baktēriju fagocitozi, producēt reaktīvā skābekḷa molekulas un antibakteriālus peptīdus, kuri spēj eliminēt plaša spektra mastītu ierosinošās baktērijas (Oviedo-Boyso et al., 2007). Gan perifērajā asinsritē cirkulējošo, gan piena dziedzerī pastāvīgi klātesošo PMNL lielāko daḷu sastāda funkcionāli nobriedušie segmentkodolainie leikocīti.

Kā redzams 3. tabulā, eksperimentālās grupas govīm pēc kompozīcijas GLP 810 infūzijām segmentkodolaino leikocītu absolūtais skaits asinīs būtiski nemainījās un visu pētījuma laiku iekḷāvās fiziologiskās normas robežās.

3. tabula / Table 3

\section{Segmentkodolaino leikocītu skaita dinamika asinīs / Dynamics of segmented neutrophils in blood}

\begin{tabular}{|c|c|c|c|c|c|c|c|}
\hline \multirow{2}{*}{ 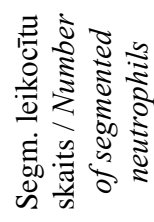 } & \multirow{2}{*}{ 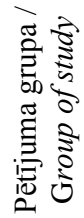 } & \multirow{2}{*}{ 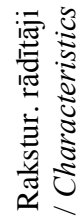 } & \multicolumn{4}{|c|}{ Pētījuma diena / Day of study } & \multirow{2}{*}{ 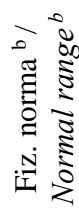 } \\
\hline & & & 1. & 3. & 7. & 21. & \\
\hline \multirow{8}{*}{ 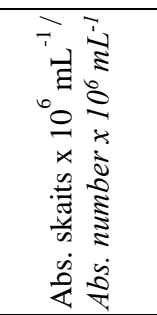 } & \multirow{4}{*}{$\begin{array}{l}\stackrel{0}{\infty} \\
\infty \\
0 \\
0\end{array}$} & $\chi$ & 1.9 & 2.3 & 1.8 & 2.7 & \multirow{8}{*}{$\begin{array}{c}0.6- \\
4.0\end{array}$} \\
\hline & & SE & 0.7 & 0.3 & 0.2 & 0.2 & \\
\hline & & $p$ & $* * * *$ & $*$ & $>0.05$ & $>0.05$ & \\
\hline & & $\mathrm{n}$ & 4 & 4 & 4 & 4 & \\
\hline & \multirow{4}{*}{ 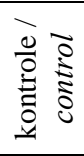 } & $\chi$ & 1.8 & $4.5^{\mathrm{a}}$ & 2.4 & 2.4 & \\
\hline & & SE & 0.3 & 1.1 & 0.2 & 0.5 & \\
\hline & & $p$ & $* * * *$ & $*,+v s .1 . d$ & $>0.05$ & $>0.05$ & \\
\hline & & $\mathrm{n}$ & 5 & 5 & 5 & 5 & \\
\hline \multirow{8}{*}{$8^{\circ}$} & \multirow{4}{*}{$\begin{array}{l}0 \\
\infty \\
0 \\
\overrightarrow{0}\end{array}$} & $\chi$ & 31.0 & 33.5 & 36.0 & 43.2 & \multirow{8}{*}{$\begin{array}{c}15- \\
45 \%\end{array}$} \\
\hline & & SE & 2.9 & 2.1 & 2.0 & 2.0 & \\
\hline & & $p$ & $>0.05$ & $*$ & $>0.05$ & $+v s .7 . \mathrm{d}$ & \\
\hline & & $\mathrm{n}$ & 5 & 5 & 5 & 5 & \\
\hline & \multirow{4}{*}{ 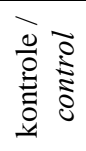 } & $\chi$ & 38.7 & $51.6^{\mathrm{a}}$ & $48.4^{\mathrm{a}}$ & $52.5^{\mathrm{a}}$ & \\
\hline & & SE & 1.7 & 3.2 & 1.6 & 2.5 & \\
\hline & & $p$ & $>0.05$ & $*$ & $+v s .1 . \mathrm{d}$ & $+v s .1 . \mathrm{d}$ & \\
\hline & & $\mathrm{n}$ & 5 & 5 & 5 & 5 & \\
\hline
\end{tabular}

a - neiekḷaujas fiziologiskajā normā / out of range, ${ }^{\mathrm{b}}$ Fielder, 2005, n - paraugu skaits / number of samples, $\chi$ - vidējais aritmētiskais / average, $\mathrm{SE}$ - standartkḷūda / standart error, $p-p$ vērtība (salīdzinot ar kontroli, būtiskuma lìmenis apzīmēts ar *, salīdzinot pētāmās grupas pa dienām, būtiskuma līmenis apzīmēts ar + ) / $p$ value (compared with control, the significance level is indicated by *, compared to the study group per day, the significance level is indicated by +$), * /+p<0.05, * * * * p=0.000, \mathrm{~d}-$ diena / day, - nav attēlots / not shown 
Turpretī kontroles grupas govīm segmentkodolaino leikocītu skaits asinīs pēc infūziju uzsākšanas 3. dienā būtiski palielinājās (no $1.8 \pm 0.3$ līdz $\left.4.5 \pm 1.1 \times 10^{6} \mathrm{~mL}^{-1}\right)$ un pārsniedza fiziologisko normu.

Pienā (skat. 7. att.) PMNL skaits pēc preparātu (GLP 810 un $0.9 \% \mathrm{NaCl}$ ) infūziju uzsākšanas būtiski palielinājās līdzīgā apmērā (par 45-63\%) abu pētāmo grupu govīm.

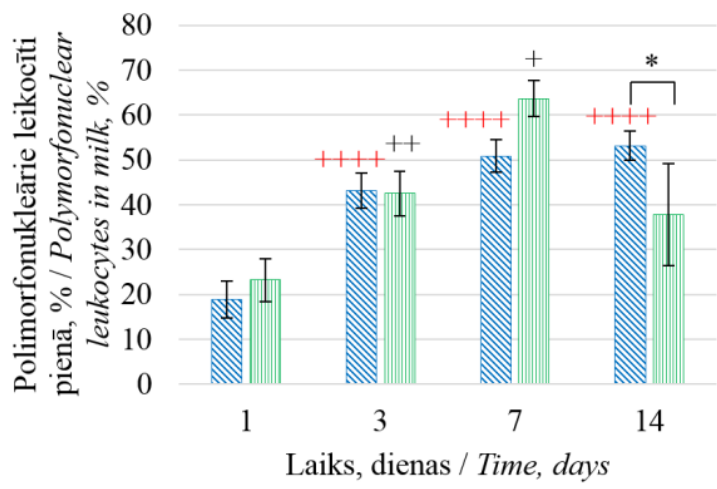

GLP 810, $\square$ Kontrole / Control, * $p<0.05$ - GLP 810 vs. kontrole / GLP 810 vs. control $;+p<0.05,++p<0.01,++++p=0.000-v s$. 1 . diena / vs. 1st day

\section{7. att. Polimorfonukleāro leikocītu daudzums pienā / Fig. 7. Dynamics of polymorfonuclear leucocytes in milk}

PMNL savstarpējā dinamika starp perifēro asinsriti un pienu liecina par šo leikocītu kompensētu savairošanos eksperimentālās grupas govju piena dziedzeros, kas ilga no 3. līdz 21. dienai perifērajā asinsritē un no 3. līdz 14. dienai piena dziedzeros. Savukārt pēc kontroles šḳīduma infūzijām kontroles grupas govju piena dziedzeros radās īslaicīga (no 3. līdz 7. dienai) iekaisuma reakcija ar sekojošu ilgstošu PMNL savairošanos asinīs (no 3. līdz 21. dienai).

Limfocītiem ir noteicošā loma iegūtās imunitātes aizsargreakcijās, jo tās ir vienīgās šunas, kas, pielietojot specifiskus membrānas receptorus, pazīst antigēnus, tajā skaitā patogēnās baktērijas (Sordillo et al., 1997). Kā liecina citu autoru (Banos et al., 2013) novērojumi, limfocītu skaita samazināšanās govīm perifērajās asin̄̄s padara tās uzņēmīgākas pret saslimšanu, un šis stāvoklis vienlaicīgi norit ar iekaisuma un iedzimtās imunitātes efektoro šūnu (t.sk. monocītu, neitrofîlo leikocītu un NK šūnu) proporcionālu skaita palielināšanos.

Kā redzams 4. tabulā, limfocītu skaits eksperimentālās grupas govju asin̄̄s 7. dienā uzrādīja samazināšanās tendenci, kad vidējais limfocītu absolūtais skaits bija zem fiziologiskās normas līmeņa. Arī limfocītu relatīvais daudzums 7. dienā bija savā zemākajā punktā, būtiski mazāks nekā 1. dienā. 
Kontroles govju asins paraugos limfocītu absolūtais skaits pētījuma laikā bija bez būtiskām izmaināâm, bet, vērtējot limfocītu procentuālo daḷu, tā pētījuma laikā izrādīja tendenci samazināties, un 21. dienā bija būtiski zemāka nekā uzsākot pētîjumu (4. tab.).

\section{Limfocītu skaita dinamika asinīs / Dynamics of lymphocytes in blood}

4. tabula / Table 4

\begin{tabular}{|c|c|c|c|c|c|c|c|}
\hline \multirow{2}{*}{ 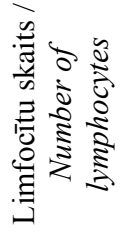 } & \multirow{2}{*}{ 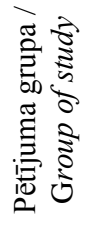 } & \multirow{2}{*}{ 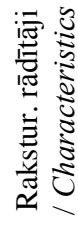 } & \multicolumn{4}{|c|}{ Pētījuma diena / Day of study } & \multirow{2}{*}{ 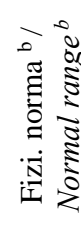 } \\
\hline & & & 1. & 3. & 7. & 21. & \\
\hline \multirow{8}{*}{ 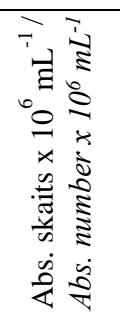 } & \multirow{4}{*}{$\begin{array}{l}0 \\
\infty \\
0 \\
\overrightarrow{0}\end{array}$} & $\chi$ & 2.6 & 2.4 & $1.6^{\mathrm{a}}$ & 2.0 & \multirow{8}{*}{$\begin{array}{c}0.6- \\
4.0\end{array}$} \\
\hline & & SE & 0.5 & 0.2 & 0.2 & 0.4 & \\
\hline & & $p$ & $*$ & $>0.05$ & $>0.05$ & $>0.05$ & \\
\hline & & $\mathrm{n}$ & 4 & 4 & 4 & 4 & \\
\hline & \multirow{4}{*}{ 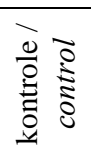 } & $\chi$ & $1.7^{\mathrm{a}}$ & $2.1^{\mathrm{a}}$ & $1.4^{\mathrm{a}}$ & $1.3^{\mathrm{a}}$ & \\
\hline & & SE & 0.3 & 0.3 & 0.1 & 0.3 & \\
\hline & & $p$ & $*$ & $>0.05$ & $>0.05$ & $>0.05$ & \\
\hline & & $\mathrm{n}$ & 5 & 5 & 5 & 5 & \\
\hline \multirow{8}{*}{ or } & \multirow{4}{*}{$\begin{array}{l}0 \\
\infty \\
01 \\
0\end{array}$} & $\chi$ & 57.7 & 47.5 & $37.7^{\mathrm{a}}$ & $44.0^{\mathrm{a}}$ & \multirow{8}{*}{$\begin{array}{c}15- \\
45 \%\end{array}$} \\
\hline & & SE & 2.8 & 1.6 & 2.0 & 1.9 & \\
\hline & & $p$ & $>0.05$ & $* *$ & $+v s .1 . \mathrm{d}$ & $>0.05$ & \\
\hline & & $\mathrm{n}$ & 5 & 5 & 5 & 5 & \\
\hline & \multirow{4}{*}{$\begin{array}{l}\overrightarrow{0} \\
\stackrel{0}{0} \\
\stackrel{0}{0} \\
\stackrel{0}{0}\end{array}$} & $\chi$ & $40.7^{\mathrm{a}}$ & $28.0^{\mathrm{a}}$ & $31.0^{\mathrm{a}}$ & $33.7^{\mathrm{a}}$ & \\
\hline & & SE & 2.7 & 1.9 & 2.0 & 2.6 & \\
\hline & & $p$ & $>0.05$ & $* *$ & $>0.05$ & $+v s .3 . \mathrm{d}$ & \\
\hline & & $\mathrm{n}$ & 5 & 5 & 5 & 5 & \\
\hline
\end{tabular}

a - neiekḷaujas fiziologiskajā normā / out of range, ${ }^{\mathrm{b}}$ Fielder, 2005, n - paraugu skaits / number of samples, $\chi$ - vidējais aritmētiskais / average, SE - standartkḷūda / standart error, $p-p$ vērtība (salīdzinot ar kontroli, būtiskuma līmenis apzīmēts ar *, salīdzinot pētāmās grupas pa dienām, būtiskuma līmenis apzīmēts ar + ) / $p$ value (compared with control, the significance level is indicated by *, compared to the study group per day, the significance level is indicated by + ), $* /+p<0.05, * * p<0.01, \mathrm{~d}-$ diena / day, - nav attelots I not shown

Turpretim limfocītu skaits eksperimentālās grupas govju pienā (skat. 8. att.) pēc GLP 810 infūziju uzsākšanas būtiski palielinājās, kas liecina par limfocītu īslaicīgi nekompensētu migrāciju no perifērās asinsrites uz tesmeni. 


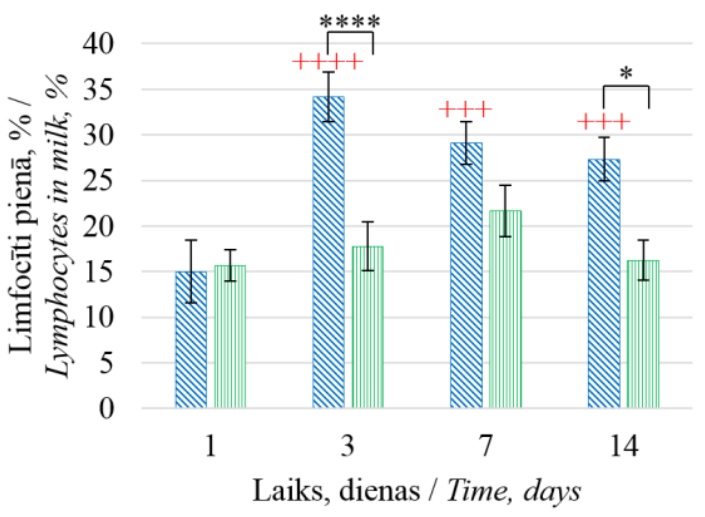

$\mathbb{\mathbb { G }}$ GLP 810, $\square$ Kontrole / Control, * $p<0.05, * * * * p=0.000$ - GLP 810 vs. kontrole / GLP 810 vs. control; +++ $p<0.001,++++p=0.000-v s .1$. diena / vs. 1st day

\section{8. att. Limfocītu daudzums pienā / \\ Fig. 8. Dynamics of lymphocytes in milk}

Imūno šūnu aktivācijas laikā tiek ekspresēti dažādi limfocītu virsmas CD marķieri; daži no tiem ir iesaistîti šūnu proliferācijāa, daži ir indikatori šūnu nobriešanai, bet citi atspoguḷo šūnu funkcionālo aktivitāti (Gulbe et al., 2017).

Kā redzams 9. att., pētījuma laikā novērotā limfocītu skaita dinamika korelēja ar CD45+ šūnu skaita izmaiņām asinīs, kas ir T šūnu blastoǵenēzes marķieris (Rivas et al., 2002). 

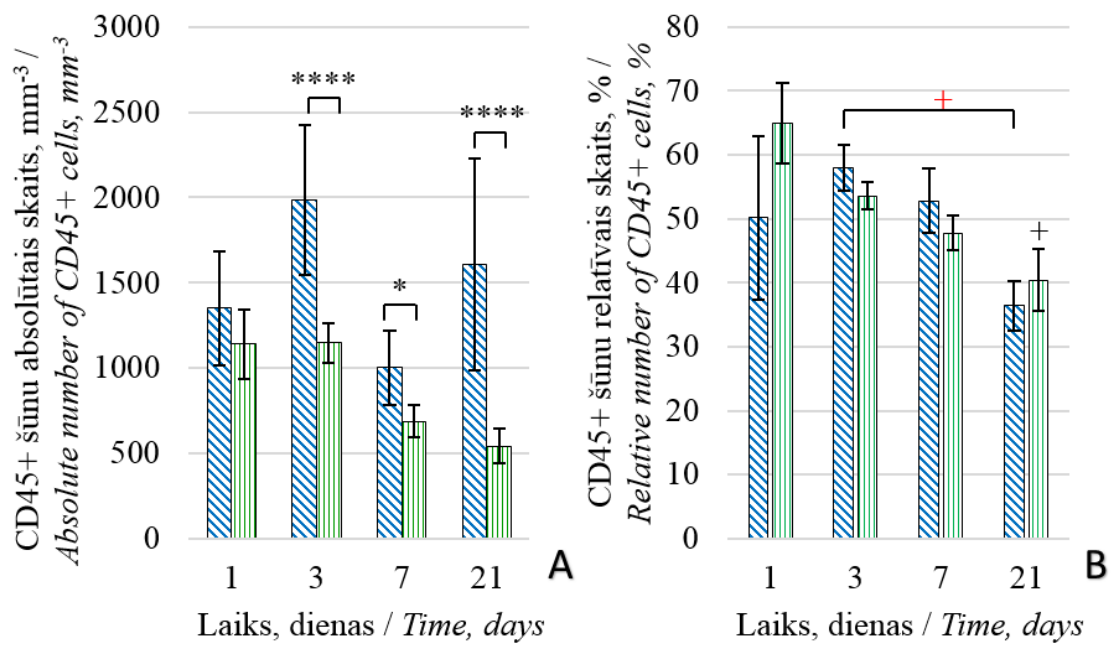

$\mathbb{1}$ GLP $810, \square$ Kontrole / Control, * $p<0.05, * * * * p=0.000$ - GLP 810 vs. kontrole / GLP 810 vs. control; $+p<0.05$ - salīdzinot izmainas pa dienām / compared to the study group per day

\section{9. att. Absolūtais (A) un relatīvais (B) CD45+ skaits asinīs / Fig. 9. Absolute (A) and relative (B) number of CD45+ in blood}

CD45+ šūnu absolūtā skaita palielināšanās, jo no 3. līdz 21. dienai š̄̄ markiiera daudzums eksperimentālās govju grupas asinīs bija būtiski lielāks nekā kontroles grupas govju asinīs (par 32-66\%), liecina par to, ka pēc kompozīcijas GLP 810 ievadīšanas piena dziedzeros ir notikusi T limfocītu migrācija no perifêrās asinsrites uz audiem.

Analizējot limfocītu skaita dinamiku asin̄̄s un pienā, jāsecina par atsevišḳu limfocītu subpopulāciju aktivitātes palielināšanos un citu subpopulāciju supresiju pēc GLP 810 infūzijām. Jādomā, ka uz piena dziedzeri notikusi limfocītu migrācija, kas ietekmējusi galvenokārt $\alpha \beta$ šūnu skaitu, par kuru liecina CD4+ šūnu absolūtā skaita samazināšanās tendence, ko novērojām 3. un 7. dienā eksperimentālo govju asinīs (10. (A) att.), un CD8+ šūnu absolūtā skaita samazināšanās tendence, kuru konstatējām 7. dienā (11. (A) att.). 

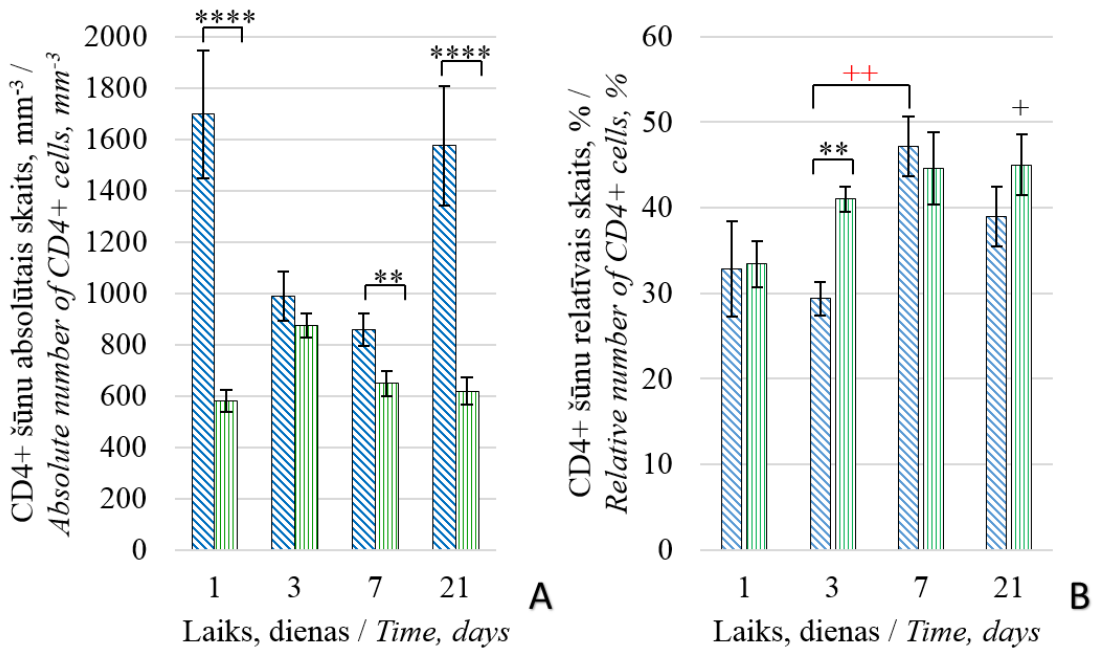

GLP 810, $\square$ Kontrole / Control, ** $p<0.01, * * * * p=0.000$ - GLP $810 v s$. kontrole / GLP 810 vs. control; $++p<0.01$ - salīdzinot izmainas pa dienām / compared to the study group per day

\section{0. att. Absolūtais (A) un relatīvais (B) CD4+ skaits asin̄̄s / Fig. 10. Absolute (A) and relative (B) number of CD4+ in blood}

Tajā pašā laikā CD4+ šūnu ralatīvais daudzums 7. dienā būtiski palielinājās (10. (B) att.), iespējams, uz citu limfocītu populāciju rēķina, uz ko norāda dabīgo galētājšūnu (NK šūnu) marķiera, CD16+ šūnu relatīvā skaita būtiskā samazināšanās. T-helperu šūnas (CD4+) ir galvenais iegūtās imunitātes reakciju ierosinātājs un, tās, iespējams, ir tikušas iesaistîtas akūta iekaisuma ierosināšanā tesmenī, kurš ilga līdz 7. dienai (t.i., 48 h pēc pēdējās infūzijas).

Savukārt citotoksisko T limfocītu markieris jeb CD8+ šūnas, kas ir T- supresori, ar lielu varbūtību, sākot no 7. dienas ir darbojušies iekaisuma nomākšanā, par ko liecina jau pieminētā CD8+ šūnu absolūtā skaita samazināšanās tendence 7. dienā. Pētîjuma 21. dienā CD8+ šūnu absolūtais skaits eksperimentālās grupas govju asins paraugos bija būtiski lielāks (par 76\%) nekā kontroles paraugos (skat. 11. (A) att). 


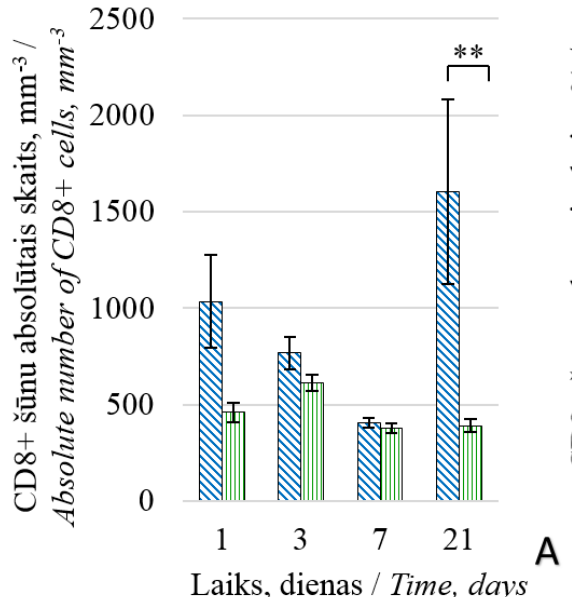

Laiks, dienas / Time, days

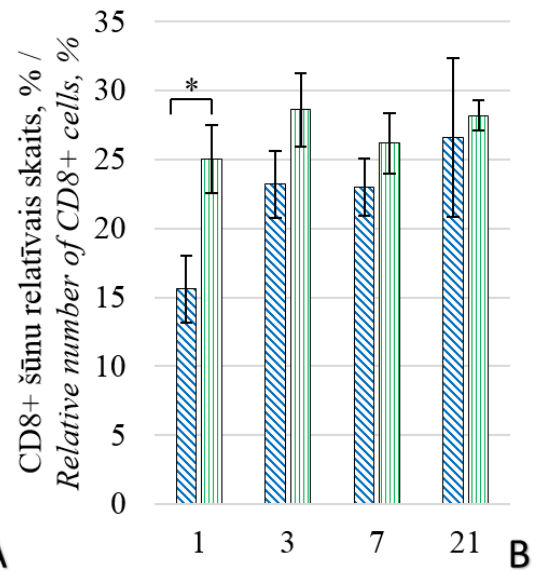

Laiks, dienas / Time, days

GLP 810, $\square$ Kontrole / Control, * $p<0.05$, ** $p<0.01$ - GLP $810 v s$. kontrole / GLP 810 vs. control

\section{1. att. Absolūtais (A) un relatīvais (B) CD8+ skaits asinīs / Fig. 11. Absolute (A) and relative (B) number of CD8+ in blood}

Līdz ar to, ka pētîjuma 3. dienā mēs konstatējām CD4+ šūnu (T-helperu) skaita samazināšanās tendenci, bet CD8+ šūnu (T-supresoru un T-citotoksisko limfocītu) skaita nosacītu nemain̄̄gumu, rezultātā eksperimentālās govju grupas asinīs notika imūnregulatorā indeksa samazināšanās (no 2.4 uz 1.2).

CD4/CD8 indekss, kas mazāks par vienu, raksturo zemu imunitāti un augstu uzņēmību pret mastītu. Ilgstoši zems CD4/CD8 indekss bieži vien liecina par nomāktu imunitāti un hronisku, subklīnisku infekciju (Park et al., 2004; Alnakip et al., 2014). Tomēr mūsu gadījumā imūnregulatorā indeksa samazināšanās, kā redzams 12. att., eksperimentālās grupas govju perifērajās asinīs bija īslaicīga, jo konstatējām to tikai 3. dienā, bet jau 7. dienā indekss bija vienlīdzīgs sākotnējam, kas saistīts ar būtisko limfocītu kopējā skaita samazinājumu govju asinīs, ko novērojām 7. dienā. Pētījuma 21. dienā indekss eksperimentālo govju asin̄̄s bija, lai gan statistiski nebūtiski, tomēr vērā ṇemami samazinājies no sākotnējā 2.4 līdz 1.8 sakarā ar CD8+ šūnu skaita palielināšanās tendenci (skat. 12. att.). 


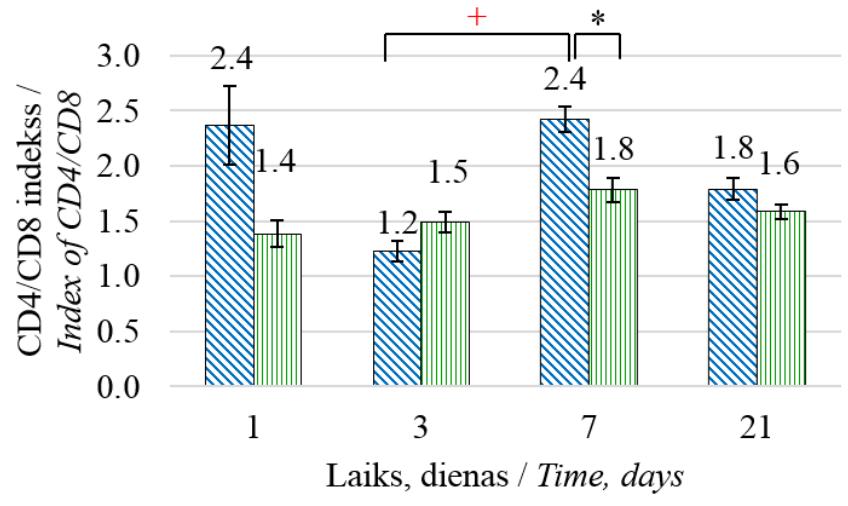

$\mathbb{Q}$ GLP 810, $\square$ Kontrole / Control, * $p<0.05$ - GLP 810 vs. kontrole / GLP 810 vs. control $;+p<0.05$ - salīdzinot izmainas pa dienām / compared to the study group per day

\section{2. att. CD4/CD8 imūnregulatorais indekss asinīs /}

Fig. 12. CD4/CD8 immunoregulatory index in blood

CD16 molekulas reprezentē NK šūnas jeb dabīgās galētājšūnas (13. att.).

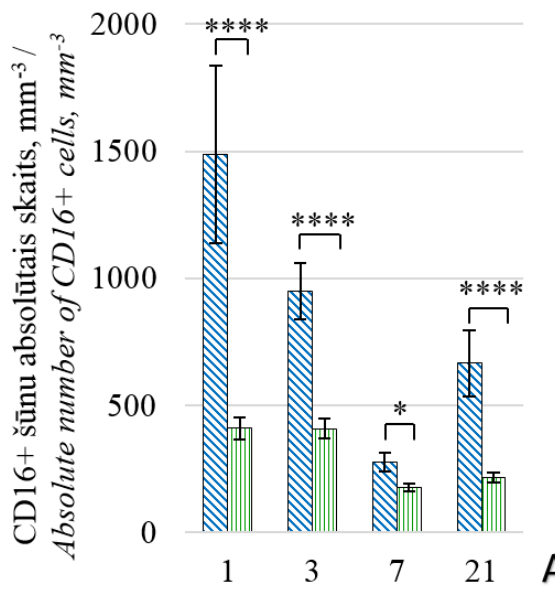

Laiks, dienas / Time, days

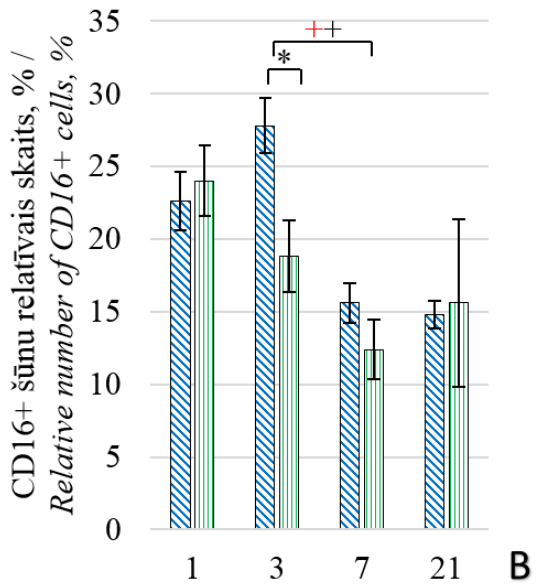

Laiks, dienas / Time, days

GLP 810, $\square$ Kontrole / Control, * $p<0.05, * * * * p=0.000$ - GLP $810 v s$. kontrole / GLP 810 vs. control; $+p<0.05$ - salīdzinot izmainas pa dienām / compared to the study group per day 
Mēs novērojām, ka NK šūnu daudzums eksperimentālās grupas govīm ievērojami samazinājās (par apm. 80\%) tikai 2 dienas pēc kompozīcijas pēdējās aplikācijas (7. dienā), kas liek domāt, ka iegūtā imunitāte uz imūnmodulatora kompozīcijas GLP 810 klātbūtni piena dziedzerī reaǵē lēnāk nekā T limfocīti.

Ir zināms, ka NK šūnas var modulēt iegūtās imunitātes reakcijas pateicoties ar citokīniem saistītai agrīnai 1. tipa T-helperu produkcijai vai mijiedarbojoties ar antigēnu prezentējošām šūnām (Banos et al., 2013). Mēs varam pieņemt, ka dabīgās galētājšūnas mēǵināja ierosināt iegūtās imunitātes Tzara darbību asin̄̄s caur T-helperu (CD4+) agrīnu migrāciju audos (Gulbe et al., 2017), uz ko norāda tas, ka eksperimentālās grupas govīm CD4+ šūnu absolūtais skaits no 3.-7. dienai uzrādīja samazināšanās tendenci, savukārt relatīvais Thelperu skaits 3. dienā bija būtiski samazinājies, ko izraisīja šo limfocītu emigrācija no perifērās asinsrites uz tesmeņa audiem.

Par T limfocītu un NK šūnu aktivizācijas stāvokli pētījuma laikā palīdz spriest šo šūnu aktivācijas un proliferācijas marḳiera, CD69 ekspresēto šūnu daudzums (skat. 14. att.).
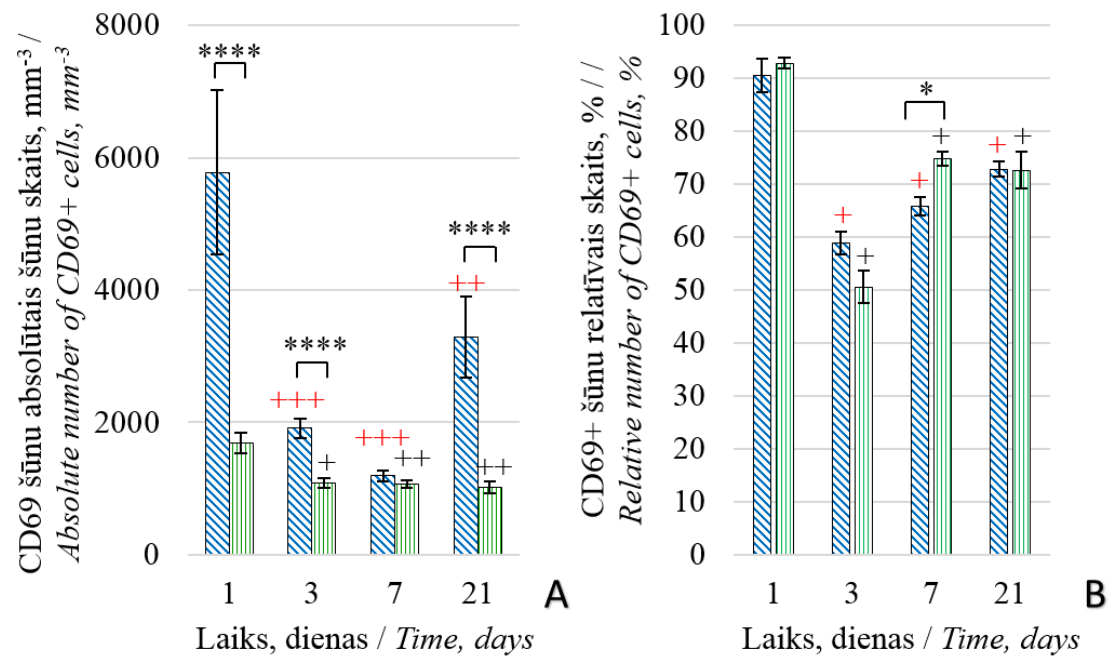

GLP 810, $\square$ Kontrole / Control, * $p<0.05$, **** $p=0.000$ - GLP 810 vs. kontrole / GLP 810 vs. control; $+p<0.05,++p<0.01,+++p<0.001-v s$. 1. diena / vs. 1st day

\section{4. att. Absolūtais (A) un relatīvais (B) CD69+ skaits asinīs / Fig. 14. Absolute (A) and relative (B) number of CD69+ in blood}

Kā liecina dati (14. att.), drīz pēc pētījuma uzsākšanas, 3. dienā, CD69+ skaits būtiski $(p<0.001)$ samazinājās, un šo šūnu daudzums 21. dienā vēl joprojām bija ievērojami mazāks nekā pirms infūziju veikšanas $(p<0.01)$, kas, iespējams, liecina par aktivizēto limfocītu migrāciju uz piena dziedzeri. 
NK šūnu un CD69 šūnu skaita viszemākais līmenis gan eksperimentālās, gan kontroles grupas govju asin̄̄s bija 7. dienā, bet 21. dienā šo šūnu skaits GLP 810 pētījuma grupā uzrādīja palielināšanās tendenci.

Piena dziedzerī ierosinātās iekaisuma reakcijas bija ilgstošas. Veicot leikocītu diferenciālo skaitīšanu pienā, novērojām, ka GLP 810 infūziju radītās izmaiņas PMNL skaitā (pieaugums par 50-60\%), limfocītu skaitā (pieaugums par $60 \%$ ) un makrofāgu skaitā (samazinājums par 65\%) ilgst visu novērojuma periodu, no 3. līdz 14. dienai. Kontroles grupā būtiskās izmaiņas šūnu sadalījumā, kur PMNL skaits palielinājās par $50-60 \%$ un makrofāgu skaits samazinājās par 30-75\%, ilga līdz 7. dienai, bet 14. dienā bija atgriezies sākotnējā stāvoklī.

Iepriekš aprakstītā imūnšūnu kinētika raksturo celulārās imunitātes norisi kā agrīnu reakciju uz imūnmodulējošās kompozīcijas aplikāciju piena dziedzeros. Pazīmes par humorālās imunitātes aktivizēšanos mēs konstatējām vēlu, pētījuma 21. dienā.

CD4+ daudzums asinīs, kā norāda pētnieki (Asai et al., 1998), korelē ar IL-2 receptorus nesošajām šūnām CD25+ (skat. 15. att.). Zināms, ka IL-2 stimulē B limfocītu augšanu un diferenciāciju, aktivē NK šūnas, ierosina T limfocītu aktivāciju un veicina laktoferīna sekrēciju. Līdz ar to, IL-2 ir liela nozīme iegūtās imunitātes atbildes reakcijas norisēs (Malek, Castro, 2010).
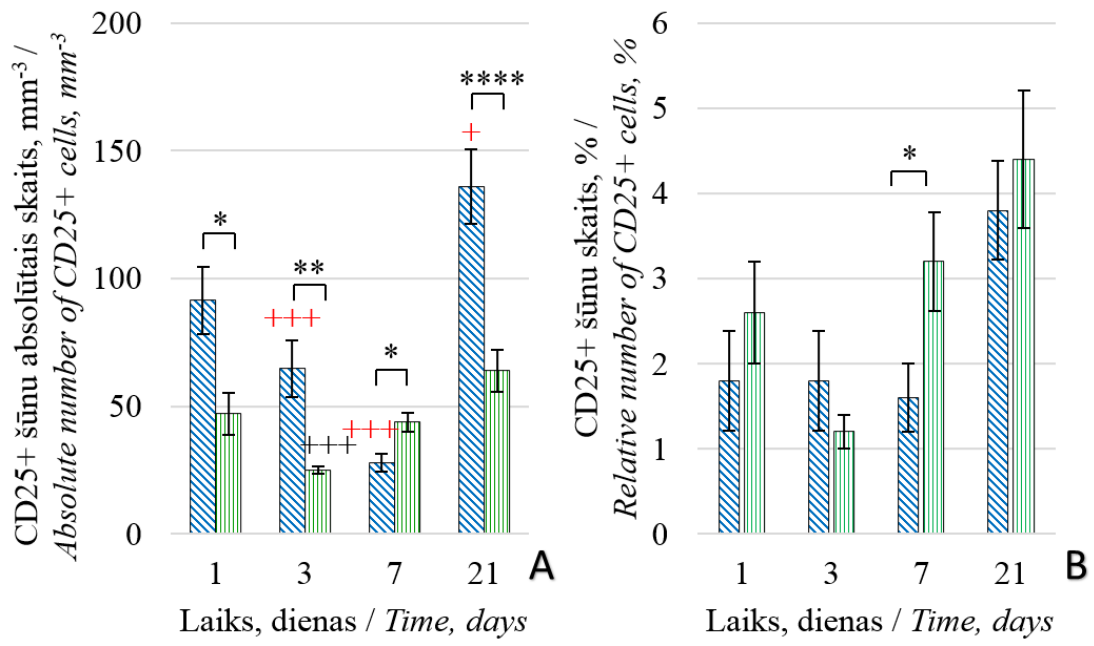

GLP 810, $\square$ Kontrole / Control, * $p<0.05, * * p<0.01, * * * * p=0.000-$ GLP 810 vs. kontrole / GLP 810 vs. control; $+p<0.05,+++p<0.001-v s$. 1. diena / vs. 1st day 
Arī mēs kompozīcijas izpētes laikā novērojām CD4+, CD8+ un CD25+ šūnu skaita samazināšanās tendenci asinīs, bet 21. dienā strauji pieauga IL-2 receptorus nesošās šūnas, salīdzinot ar 7. dienu $(p=0.000)$, kas norāda uz vēlīnu T limfocītu aktivāciju perifērajā asinsritē. Turklāt, iespējams, ka CD25+ šūnu savairošanās ir ietekmējusi arī B limfocītu aktivizēšanos, par ko liecina CD19+ šūnu absolūtā skaita palielināšanās tendence eksperimentālās grupas govju asinīs pētījuma 21. dienā (vs. 7. diena).

\subsection{Iekaisuma citokīnu ekspresija}

Lai izvērtētu iekaisuma gaitu piena dziedzeros, tika veikta imūnreaktīvo šūnu iezīmēšana un noteikta interleikīna 1 (IL-1), audzēju nekrozes faktora-alfa (TNF- $\alpha$ ), interleikīna 10 (IL-10), beta-defensīna 2 (BD-2) un kaspāzes-6 ekspresija leikocītos.

IL-1 un TNF- $\alpha$ ir galvenie iekaisumu veicinošie citokīni, un tie ir iesaistīti gan lokālās, gan sistēmiskās imūnatbildes norisēe, stimulējot neitrofîlo leikocītu hemotaksi no perifērās asinsrites uz piena dziedzera audiem, kur tie ierodas jau dažas minūtes pēc infekcijas sākuma (Rainard, 2000; Alluwaimi, 2004; OviedoBoyso et al., 2007; Abbas et al., 2014). Veselos piena dziedzeros TNF- $\alpha$ klātbūtne netiek konstatēta (Bannerman, 2009).

Pētījuma sākumā pirms preparātu infūzijas uzsākšanas mēs konstatējām, ka abu pētāmo grupu pienā TNF- $\alpha$ ir sastopams galvenokārt makrofāgos nelielā daudzumā, ar līdzīgu biežumu (16-25\%), bez korelācijas ar SŠS un patogēnajām baktērijām. Kā redzams 16. att., uzsākot kompozīcijas GLP 810 infūzijas, TNF- $\alpha$ daudzums eksperimentālo govju piena dziedzeros kopumā palielinājās par apm. $130 \%$ un turpmākajā novērojumu periodā no 3. līdz 7. dienai palika nemainīgi augstā līmen̄̄, kas liecina par šī citokīna nozīmi iekaisuma uzturēšanā, t.i., PMNL aktivitātes uzturēšanā, jo, kā zināms, attiecīgajā periodā no 3. līdz 7. dienai arī PMNL skaits pienā bija būtiski paaugstināts, bet iekaisuma laikā neitrofîlie leikocīti ir galvenie šì citokīna izdalītāji. 


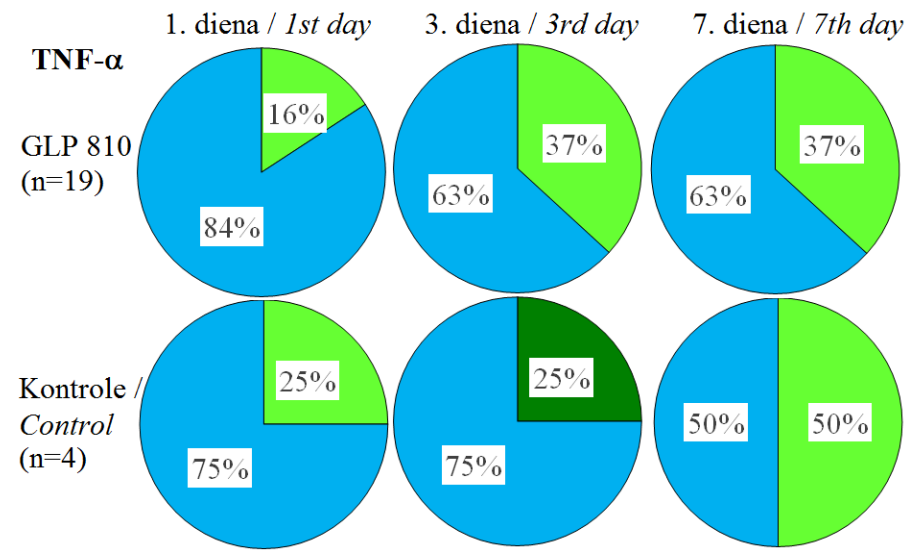

nav / negative, _ maz / few, $\square$ vidēji daudz / medium high

16. att. TNF- $\alpha$ ekspresija piena imūnšūnās /

Fig. 16. TNF- $\alpha$ expression in milk leukocytes

Mēs konstatējām, ka TNF- $\alpha$ ekspresija bija būtiski lielāka paraugos ar augstu SŠS (vidēji 3.4 \pm 0.3 milj. šūnu $\mathrm{mL}^{-1}$ ) nekā paraugos ar zemu SŠS (vidēji $72.0 \pm 8.4$ tūkst. šūnu $\mathrm{mL}^{-1}$ ), kā arī citokīna izdali 1. dienā konstatējām tikai tajos piena paraugos, kuros PMNL skaits bija lielāks nekā 10\%, bet limfocītu skaits mazāks nekā $10 \%$, un šāds leikocītu sadalījums ir raksturīgs inficētam piena dziedzerim (Alhussien et al., 2015).

IL-1, tāpat kā TNF- $\alpha$, ir iekaisumu veicinošs citokīns, bet ir zināms, ka IL-1 dalība mastīta patoǵenēzē nav izškiroša, un tās nozīmīgumu ietekmē ierosinātāja veids (Shuster, Kehrli, 1995; Alluwaimi, 2004).

Pēc kompozīcijas GLP 810 ievadīšanas, IL-1 ekspresija piena dziedzeros pakāpeniski samazinājās, un 7. dienā tā bija par apmēram 80\% mazāka nekā 1 . dienā (skat. 17. att.) 


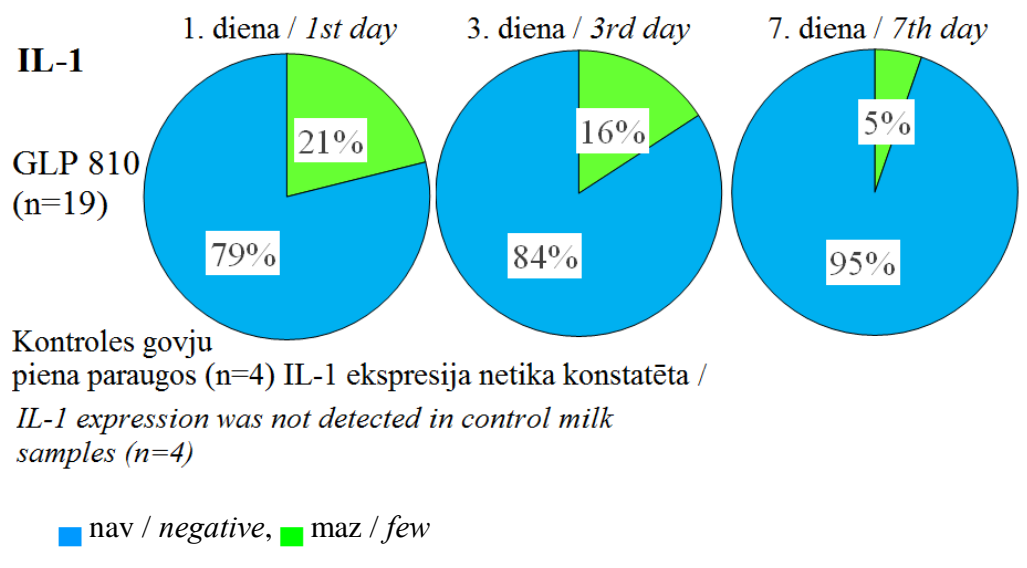

\section{7. att. IL-1 ekspresija piena imūnšūnās / Fig. 17. IL-1 expression in milk leukocytes}

Domājams, ka IL-1 izdalīšanās samazinājās sakarā ar (1) makrofāgu skaita samazināšanos, (2) pretiekaisuma citokīna IL-10 pieaugošo izdalīšanos un (3) apoptozes aktivitātes palielināšanos. Pienā par to liecina kaspāzes-6 imūnreaktīvo šūnu sastopamības pieaugums 3. dienā par apmēram $60 \%$ un makrofāgu skaita samazināšanās par vidēji $65 \%$, sākot ar 3. dienu, un šis makrofāgu skaita procentuālais samazinājums 7 . dienā bija pat vēl mazliet pieaudzis $(70 \%)$.

To apliecina arī citi autori, ka IL-1 galvenais izdalītājs ir monocīti asinīs un makrofāgi pienā, bet apoptozes rezultātā IL-1 daudzums samazinās (Alluwaimi, 2004; Lopez-Castejon, Brough, 2011).

Analizējot noteikto iekaisumu veicinošo citokīnu (IL-1 un TNF- $\alpha$ ) dinamiku, varam secināt, ka mūsu pielietotā kompozīcija GLP-810 ir izraisījusi kontrolētu iekaisuma reakciju tesmeņos, kā rezultātā samazinājās patogēno mikroorganismu skaits pienā un radās îslaicīgi traucējumi piena sekrēcijā.

Beta defensīnu-2 raksturo baktericīda ietekme uz patogēnajiem mikroorganismiem un imūnmodulējoša ietekme gan specifiskās, gan nespecifiskās imunitātes ietvaros. Beta defensīni veicina plaša spektra leikocītu hemotaksi uz iekaisuma vietu (Luenser, Ludwig, 2005; Meade et al., 2014).

Mūsu veiktajā pêtījumā BD-2 izdale biežuma un intensitātes izteiksmē eksperimentālās govju grupas pienā palielinājās jau 3. dienā pēc GLP 810 infūziju uzsākšanas, bet būtiski palielinājās 7 . dienā, kad $80 \%$ no piena dziedzeriem bija sekrēcijas traucējumi un lielākā daḷa no tiem (93.3\%) saturēja BD-2 (skat 18. att.). 


\section{1. diena / 1st day}

3. diena / 3rd day

7. diena / 7th day
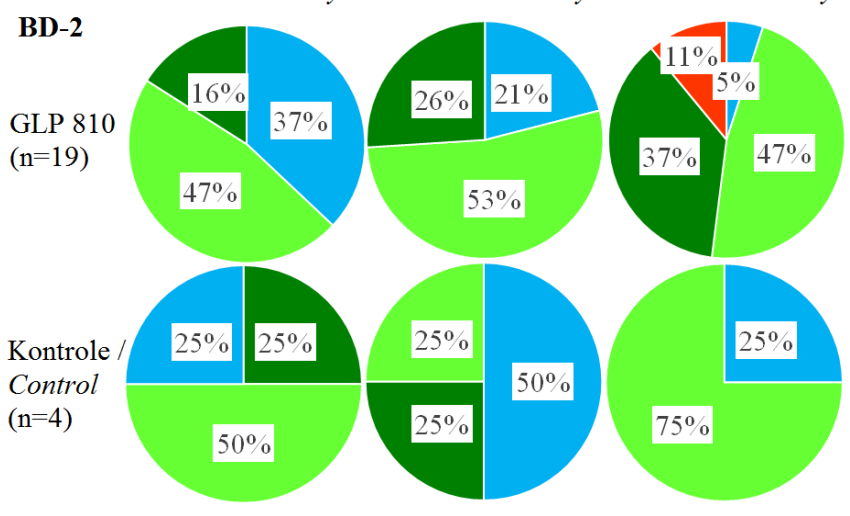

nav / negative, maz / few, $\square$ vidēji daudz / medium high, $\square$ daudz / high

\section{8. att. BD-2 ekspresija piena imūnšūnās / Fig. 18. BD-2 expression in milk leukocytes}

Septîtā diena raksturojās arī ar viszemāko nosacīti patogēno baktēriju skaitu, zemāko S. aureus, Enterobacteriaceae dzimtas un Staphylococcus spp. baktēriju skaitu pienā. Secinām, ka BD-2 aktivitāte pēc GLP 810 infūzijām palielinājās, un tai bija sava, iespējams, ka nozīmīga loma patogēno baktēriju eliminēšanā, PMNL un limfocītu migrācijas veicināšanā uz piena dziedzeriem. Kontroles grupā BD- 2 konstatējām variabli un novērotās izmaiņas bija statistiski nebūtiskas.

IL-10 pieder galvenā loma iekaisuma nomākšanā, un tā darbībai ir aizsargājošs efekts, ierobežojot audu bojājumus un veicinot audu atjaunošanos pēc infekcijām (Asadullah et al., 2003; Bannerman, 2009).

Mēs konstatējām, ka, līdz ar PMNL skaita palielināšanos pienā, pētījuma laikā IL-10 ekspresijas biežums un intensitāte eksperimentālās govju grupas piena paraugos būtiski palielinājās un visaugstākā IL-10 aktivitāte bija 7. dienā ( $p<0.01)$, kad šo citokīnu konstatējām gandrīz visos (18 no 19) eksperimentālās govju grupas piena paraugos, un lielākajā daḷā (58\%) no tiem šūnas IL-10 saturēja vidēji lielā koncentrācijā. Kontroles grupas ceturkšṇos IL-10 ekspresija pētījuma laikā uzrādīja samazināšanās tendenci (skat. 19. att.).

IL-10 nozīmi iekaisuma mazināšanā apstiprina novērojums, ka š̄̄ imūnregulatorā citokīna ekspresija bija būtiski lielāka pienā ar paaugstinātu somatisko šūnu (Kendala koef. 0.774, $p=0.000$ ) un kopējo baktēriju skaitu (Kendala koef. 0.676, $p=0.005$ ). 


\section{1. diena / 1st day}
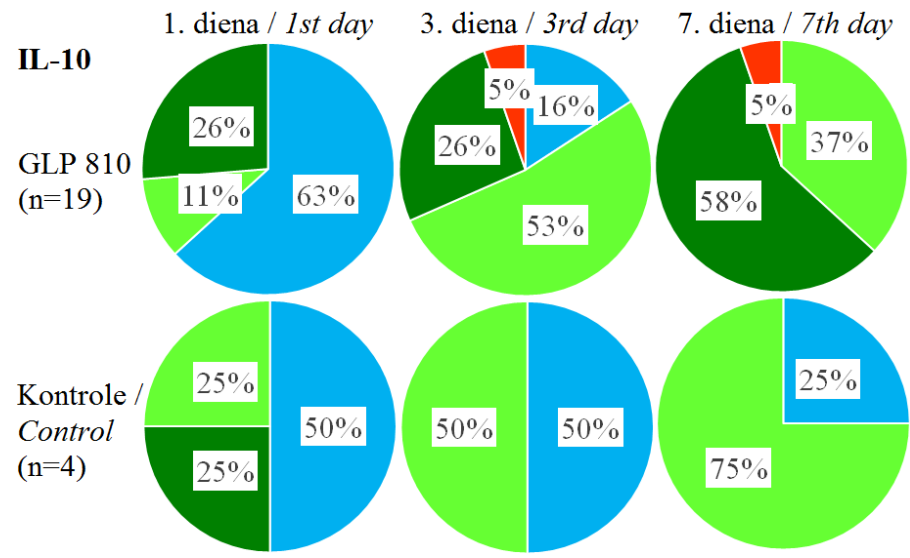

nav / negative, — maz / few, — vidēji daudz / medium high, — daudz / high

\section{9. att. IL-10 ekspresija piena imūnšūnās / \\ Fig. 19. IL-10 expression in milk leukocytes}

In vitro pētījumos ir noskaidrots, ka IL-10 nomāc CD4+ šūnu proliferāciju un inhibē citokīnu veidošanos šajās šūnās, galvenokārt ietekmējot Th1 limfocītu subpopulāciju. Uz CD8+ šūnām IL-10 neiedarbojas supresīvi, dažos apstākḷıs pat aktivējot imūnregulatoros T limfocītus. Savukārt pretiekaisuma citokīna ietekme uz NK šūnām galvenokārt esot stimulējoša, uzlabojot šo šūnu citotoksisko aktivitāti (Asadullah et al., 2003).

Arī mūsu pētījums pierādīja, ka IL-10 aktivitāte GLP 810 pētījuma grupas govju piena dziedzeros ir nodrošinājusi balansētu iekaisuma reakciju ar celulārās imunitātes aktivizēšanos lokāli piena dziedzeros, kas ilga līdz pētījuma 14. dienai (jeb 9 dienas pēc pēdējās infūzijas) un rezultējās ar patogēno baktēriju skaita un vidējā SŠS samazināšanos.

Līdz ar to, ir pierādīta promocijas darba hipotēze, ka, pielietojot govīm intramammāri dabīgas vielas ar imūnmodulējošām īpašībām, ir iespējams pastiprināt organisma vispārējo un piena dziedzeru lokālo imūnatbildi, kas rezultētos ar mastīta ierosinātāju klātbūtnes ierobežošanu tesmenī. Turklāt mēs konstatējām, ka kompozīcijas GLP 810 intramammāro infūziju ierosinātā imūnmodulācija bija balansēta, ietverot vienlaicīgi fagocītisko šūnu migrāciju uz tesmeņa audiem un pretiekaisuma faktoru izdali, kas nodrošināja kontrolētu šūnu imunitātes aktivēšanos fiziologiskās normas robežās laikā no 3. līdz 14. pētījuma dienai, kā arī iespējamu humorālās imunitātes aktivēšanos 21. dienā. 


\section{SECINĀJUMI}

1. Piena kvalitātes prasībām neatbilstošus paraugus (vairāk nekā 100 tūkst. baktēriju $\mathrm{kvv} \mathrm{mL}^{-1}$ ), kas iegūti no bioloǵiskiem piena ražošanas ganāmpulkiem, visbiežāk konstatē rudenī $(21.0 \%)$ un ziemā $(20.6 \%)$, bet pavasarī un vasarā neatbilstošo paraugu skaits sastāda attiecīgi $11.9 \%$ un $8.3 \%$. Vislielāko kopējo baktēriju skaitu (vidēji 243 tūkst. kvv mL ${ }^{-1}$ ) konstatē rudenī iegūtā pienā, bet pārējos gadalaikos baktēriju skaits ir būtiski zemāks (24-72 tūkst. kvv mL $\left.{ }^{-1}\right)$. Lielo ganāmpulku pienā ir vislielākais kopējais baktēriju skaits (180 tūkst. $\mathrm{kvv} \mathrm{mL}^{-1}$ ), mazāks tas ir mazajos un vidēja lieluma ganāmpulkos (attiecīgi 48 tūkst. un 31 tūkst. kvv mL ${ }^{-1}$ ). Dažu baktēriju klātbūtne, t.i., K. kristinae un Corynebacterium spp., ir raksturīga mazo ganāmpulku pienā, bet Enterobacteriaceae dzimtas mikroorganismi tiek izolēti galvenokārt no lielo ganāmpulku piena.

2. Visbiežāk no piena izolētie mikroorganismi ir koagulāzes negatīvie stafilokoki (KNS) $30.9 \%$ paraugos, S. aureus $25.2 \%$, Enterobacteriaceae dzimtas mikroorganismi $13.7 \%$ un K. kristinae $13.1 \%$ paraugos. Retāk izolē Micrococcus, Corynebacterium, Streptococcus un Bacillus spp. (4.3-7.0\%). Vislielāko somatisko šūnu skaita palielināšanos pienā izsauc S. aureus $\left(739\right.$ tūkst. $\left.\mathrm{mL}^{-1}\right)$, Corynebacterium spp. (1059 tūkst. $\mathrm{mL}^{-1}$ ) un S. aureus asociācijā ar Enterobacteriaceae dzimtas baktērijām (1607 tūkst. $\left.\mathrm{mL}^{-1}\right)$.

3. Vislielāko antibakteriālo aktivitāti in vitro uzrāda lizocīms (15.0 līdz $19.5 \mathrm{~mm})$, pienskābe $(8.3 \mathrm{lī} d z 24.3 \mathrm{~mm})$ un laktoferīns $(8.0 \mathrm{li} \mathrm{dz}$ $11.0 \mathrm{~mm}$ ). Kompozīcija GLP 810 (sastāvā ir glikopeptīds $10 \mathrm{mg}$, lizocīms $300 \mathrm{mg}$, pienskābe $500 \mathrm{mg}$ ), uzrāda antagonistisku iedarbību pret abu fenotipu $S$. aureus celmiem un E. coli, radot no 9.0 līdz $15.0 \mathrm{~mm}$ lielu auguma nomākumu.

4. Kompozīija GLP 810 in vivo, ievadot intramammāri 3 reizes ar $48 \mathrm{~h}$ intervālu, rada patogēno baktēriju ierobežojošu ietekmi piena dziedzeros un kontrolētu celulārās imunitātes aktivēšanos fizioloǵiskās normas robežās laikā no 3. līdz 7. pētījuma dienai, kāa arī iespējamu humorālās imunitātes aktivēšanos 21 . dienā, uz ko norāda:

1.1. pēc infūziju uzsākšanas GLP 810 pêtījuma grupas govīm būtiski palielinās no mastīta ierosinātājiem brīvo piena dziedzeru skaits (par 73\%), kā arī samazinās kopējais nosacīti patogēno baktēriju skaits par $87-92 \%$ (no 50.7 tūkst. līdz 4.2 tūkst. $\mathrm{kvv} \mathrm{mL}^{-1}$ ) un kopējais baktēriju skaits par 12-24\% (no 525 tūkst. līdz 398 tūkst. šūnu $\mathrm{mL}^{-1}$ ), iespējams, pateicoties antibakteriālā peptīda BD-2 ekspresijas pieaugumam;

1.2. segmentkodolaino leikocītu absolūtais skaits GLP 810 pētîjuma grupas govju asin̄̄s būtiski nemainās un iekḷaujas fiziolog̣iskās 
normas robežās visu pētījuma laiku, bet pienā PMNL skaits palielinās, kas liecina par balansētu PMNL savairošanos lokāli piena dziedzeros, ko nodrošina, iespējams pretiekaisuma citokīna IL-10 aktivitāte;

1.3. GLP 810 pētījuma grupas govīm pēc infūziju uzsākšanas limfocītu skaits asinīs uzrāda samazināšanās tendenci, bet būtiski samazinās pētījuma 7. dienā, savukārt pienā limfocītu skaits būtiski palielinās, kas vēlreiz apliecina lokālās imunitātes aktivēšanos;

1.4. CD4+, CD8+ un CD25+ šūnu skaits GLP 810 pētījuma grupas govju asin̄̄s samazinās, bet 21. dienā strauji pieaug imūnregulatoro $\mathrm{T}$ limfocītu skaits un IL-2 receptorus nesošo šūnu skaits, kas norāda uz vēlīnu $\mathrm{T}$ limfocītu aktivāciju perifērajā asinsritē.

\section{PRIEKŠLIKUMI}

1. N̦emot vērā, ka imūnmodulācija un patogēno baktēriju ierobežošana optimālā mērā ir novērojama jau trešajā pētījuma dienā, iesakām kompozīcijas GLP 810 intramammārās infūzijas ar subklīnisko mastītu slimos govju piena dziedzeros veikt vienu reizi, bet pēc nepieciešamības atkārtot infüziju pēc 21 dienas.

2. Lai izvairītos no somatisko šūnu skaita krasa pieauguma pienā, pirms kompozīcijas GLP 810 ievadīšanas ieteicams pārliecināties par piena sekrēcijas stāvokli un ievadīt kompozīciju tikai problemātiskajos tesmeṇa ceturkšņos (ar SŠS virs 200 tūkst. $\mathrm{mL}^{-1}$ vai latenti inficētos).

3. Lai laicīgi atklātu subklīnisko mastītu un uzsāktu ārstēšanu, ieteicams noteikt tesmeņa ceturkšņos SŠS, KBS un laktozes daudzumu pienā. Konstatējām, ka no visiem mastīta gadījumiem $42 \%$ ir paaugstināts vienlaicīgi SŠS (vairāk nekā 200 tūkst. $\mathrm{mL}^{-1}$ ) un KBS (vairāk nekā 100 tūkst. $\mathrm{mL}^{-1}$ ), savukārt $33 \%$ mastìta gadījumos ir vienlaicīgi paaugstināts SŠS un KBS, kā arī samazināts laktozes daudzums (mazāk nekā 4.65\%). 


\section{INTRODUCTION \\ Topicality of the research}

The animal immune status plays a key role in the development of mastitis after an invasion of bacteria into mammary glands. Mastitis or udder inflammation is the most common illness affecting dairy cattle and is the main cause of economic losses in milk production worldwide (Maréchal et al., 2011), while subclinical mastitis is a particular condition of the mammary gland characterized by a long-term low-intensity infection and subsequent damage of the mammary gland tissue which results in a decrease in milk quality. The treatment of mastitis is still based on the whole on the usage of antibiotics, but the overall cost of therapy is quite expensive, the effectiveness of antibiotics is constantly decreasing, and is associated with significant harm to public health as the persistence of residues in milk can promote the development of antibiotic resistance (Gyles, 2008; Persoons et al., 2012). The fight against the development of antimicrobial resistance of bacteria, which involves a prudent and a rational use of antibiotics, is one of the priority tasks in the human health sector and veterinary medicine both in Latvia and in the EU as a whole, but alternative methods for the treatment of mastitis are needed to carry out this task (Izglitīibas un Zinātnes ministrija, 2017).

In the Member States of the European Union, Regulation 834/2007 on organic production and labelling of organic products determines the maintenance of animal health by encouraging the natural immunological defence of the animal. Chemically synthesised allopathic veterinary medicinal products including antibiotics may be used only if the use of phytotherapeutic, homeopathic and other products (incl. immunological veterinary medicines) is inappropriate in the treatment of the desease. Due to these problems, in recent years intensive research has been carried out to create natural antimicrobial agents. An important alternative to antibiotic therapy is the immunomodulators with antibacterial properties. The authors have shown that the use of natural substances is also effective for cows in the treatment of mastitis (Kai et al., 2002; Cao et al., 2007; Klostermann et al., 2010; Soleimani et al., 2010; Espeche et al., 2012; Frola et al., 2012).

Although cow's milk contains a wide range of microorganisms and in some cases, their presence is associated with mastitis, a host immune status plays a key role in development of chronic subclinical infections. Based on the previously mentioned assumption, we formulated the research hypothesis: it is possible to improve a local cellular immune response by intramammary infusions of natural substances with immunomodulating properties by limiting growth of pathogenic bacteria in the udder. 


\section{Research thesis}

1) The microbial population in bovine mammary glands depends on a variety of factors, including the season and herd size;

2) The type / species of invading bacteria has a significant effect on the total bacterial count and somatic cell count in milk;

3) Cow milk contains a variety of substances with immunomodulatory and antibacterial properties, whose activity against mastitis causing bacteria can be partially assessed in vitro;

4) Administering these natural substances intramammarily into cows, the response of cellular and humoral immunity is activated;

5) The activation of immunity contributes to the growth limitation of pathogenic bacteria in cows' mammary glands.

\section{Aim of the research}

The aim of the study is to investigate the bacterial diversity in milk obtained from Latvian organic dairy farms and to develop a composition from natural components with immunomodulatory properties to control mastitis.

\section{Objectives of the doctoral thesis}

1) To investigate the diversity of microorganisms in milk obtained from Latvian organic dairy farms in accordance with the season;

2) To find out prevalent subclinical mastitis causing bacteria;

3) To detect an antimicrobial activity for natural substances as well as their compositions with immunomodulatory properties in vitro against the prevalent mastitis causing bacteria using the well diffusion technique;

4) To carry out in vivo investigations of one antibacterial composition and to demonstrate its immunomodulating action which might result in the control of mastitis causing bacteria in the udder.

\section{Scientific novelty of the research}

1) Evaluation of the presence of microorganisms in cow's milk obtained from organic farming in Latvia has been made depending on herd size and the season.

2) Collaborating with researchers of the Latvian University and the Riga Stradiņš University, a composition from natural substances of milk origin, i.e., lactic acid, lysozyme and L. helveticus glycopeptide has been developed for the growth limitation of mastitis causing bacteria. 
3) For the first time in Latvia leukocytes both in cow milk and blood were assesed, as well as the number of lymphocyte surface molecules (CD4, CD8, CD16, CD19, CD25, CD45, CD69).

4) For the first time in Latvia in veterinary medicine an immunohistochemical method has been used for the interpretation of immunological processes in secrete of infected cows' mammary glands by determining the expression of IL- 1 , IL- 10 , TNF- $\alpha$, caspase- 6 and beta-defensin- 2 in immune cells.

5) New data on abnormal processes in cows with subclinical mastitis were obtained.

\section{Personal contribution}

1) Drawing up a research plan.

2) Establishment of contacts with owners of organic herds with a view to obtaining permission to remove milk samples from their cattle.

3) Attendance of the organic production herds selected for the study, getting information on selected cows for the study and obtaining milk samples.

4) Transportation of milk samples to a laboratory and subsequent microbiological examination.

5) Preparation of isolated cultures of mastitis causing agents for long-term storage and maintenance of pure cultures viability.

6) In vitro measurements of the antimicrobial activity of immunomodulatory substances and their compositions, which involve incubation of pure cultures of mastitis causing bacteria.

7) In vivo preliminary investigation of immunomodulatory compositions for certain cows.

8) Administration of the intramammary composition GLP 810 into cows' mammary glands, removal of milk samples, transportation to laboratories and subsequent microbiological examination.

9) Differential counting of leukocytes in milk sediment.

10) Data analysis and statistical processing of the results obtained from microbiological, cytological, immunohistochemical, hematological and immunological investigations.

\section{Structure and volume of the doctoral thesis}

The doctoral thesis is presented on 140 pages including 16 tables and 43 figures, and it is structured in five chapters consisting of the introduction, the survey of the scientific sources, the material and methods, the results of investigations, and the discussion. The thesis contains 4 main conclusions and 3 proposals, 291 references and 14 annexes. 


\section{MATERIAL AND METHODS}

The study was carried out in three stages, where:

1) in the first stage of the study, a diversity of microorganisms in the milk obtained in 14 Latvian organic farms in accordance with the cow herd size and the season was investigated.

2 in the second stage, antimicrobial activity of natural substances with immunomodulatory properties was determined in vitro against prevalent mastitis causing bacteria by well diffusion technique.

3 ) in the third stage, activity of an immunomodulatory composition GLP 810 in vivo has been evaluated followed by the intramammary infusions of the composition for cows with subclinical mastitis.

\section{Time and object of the research and its characterization}

In the first stage of the research, from December 2011 to November 2012, samples of raw milk were collected from 14 organic dairy cattle herds, including four regions of Latvia: three herds in Kurzeme (quarter milk samples from 40 cows were obtained), two herds in Vidzeme (quarter milk samples from 40 cows were obtained), three herds in Latgale (quarter milk samples from 41 cows were obtained), six herds in Zemgale (quarter milk samples from 106 cows were obtained), thus, in general, examining quarter milk samples from 227 cows.

The size of the herds varied from 3-120 lactating cows per herd, and we divided them into the following groups for further aggregation of results:

- Group A - small herds with 3-30 lactating cows. In this group, we analyzed the milk samples of four herds with the number of tested cows' milk samples $\mathrm{n}=86$;

- Group B - medium herds, with 31-60 lactating cows. We analyzed milk samples of five herds with the number of tested cows' milk samples $\mathrm{n}=$ 244;

- Group C - large herds with 61-120 lactating cows. We analyzed milk samples of five herds with the number of tested cows' milk samples $\mathrm{n}=$ 210.

From each herd, 15 lactating cows were selected, preferably including five healthy, five with slightly/temporarily increased somatic cell count (SCC), and five cows with chronic subclinical mastitis. In herds, where the number of dairy cows was less than 15 , we collected quarter milk samples from all lactating cows' mammary glands. If, during sampling, any of the cows included in the study were dry or slaughtered, then if possible, another equivalent lactating cow (taking into consideration the lactation and health condition of the udder) was included in the study. Subsequently, from these cows, samples of milk were examined four times a year, with a total of 540 quarter milk samples, i.e., 140 samples in winter, 134 in spring, 160 in summer, and 106 samples in autumn. 
In the second phase of the study, we carried out in vitro measurements of antibacterial activity of natural substances with immunomodulatory characteristics against the most common mastitis causative bacteria, and it was carried out between May 2012 and May 2015.

The antibacterial activity of immunomodulatory components, compositions and control preparations was tested on seven bacterial cultures isolated from aseptically removed milk samples - cows from organic herds for which subclinical mastitis was detected during the first phase of the study. The identification of these seven strains of the microorganisms was carried out at the Scientific Institute of Food Safety, Animal Health and Environment 'BIOR' using 'MALDI Biotyper' (Bruker, Germany) and 'BBL Crystal Gram-positive and Enteric/Nonfermenter ID' (Becton, Dickinson and Company, USA) identification systems of microorganisms. The identified strains we used in the in vitro studies were:

1) S. aureus (typical strain);

2) S. aureus (small colony variant);

3) S. saprophyticus;

4) S. haemolyticus;

5) E. coli;

6) Serratia liquefaciens;

7) Citrobacter freundii.

The immunomodulatory components and their compositions used in this study, with a few exceptions ${ }^{1}$, were made at the August Kirchenstein Institute of Microbiology and Virology of Rīga Stradin̄š University (RSU, MVI):

1) lysozyme (AppliChem GmbH, Germany);

2) lactoferrin (Alfa Aesar, Thermo Fisher Scientific, Germany);

3) lactoferrin (from colostrum);

4) lactic acid (BDH Prolabo, Ireland);

5) casein (from colostrum);

6) broadleaf plantain (Plantago major) extract (1:3 with $0.9 \mathrm{NaCl})$;

7) chamomile (Matricaria recutita) extract;

8) L. helveticus $\left(10^{9} \mathrm{kvv} \mathrm{g}^{-1}\right)$ glycopeptide;

9) L. reuterii (viable lyophilised lactic acid bacteria $10^{7} \mathrm{kvv} \mathrm{g}^{-1}$ );

10) P. pentosaceus (viable lyophilised lactic acid bacteria $10^{7} \mathrm{kvv} \mathrm{g}^{-1}$ );

11) L. helveticus glycopeptide 5\% and casein 95\%;

12) L. helveticus glycopeptide 5\% and lysozyme $95 \%$;

13) lysozyme $100 \mathrm{mg}$, lactoferrin $100 \mathrm{mg}$, L. helveticus glycopeptide $10 \mathrm{mg}$, lactic acid $1 \mathrm{~mL}$;

${ }^{1}$ Lysozyme (AppliChem GmbH, Germany), lactoferrin (Alfa Aesar, Thermo Fisher Scientific, Germany), and lactic acid (BDH Prolabo, Ireland) 
14) lysozyme $100 \mathrm{mg}$, lactoferrin $100 \mathrm{mg}$, L. helveticus glycopeptide $10 \mathrm{mg}$, lactic acid $1 \mathrm{~mL}$; broadleaf plantain concentrate $1 \mathrm{~mL}$;

15) L. reuterii glycopeptide $90 \%$, lysozyme $10 \%$;

16) B. lactis glycopeptide $90 \%$, lysozyme $10 \%$;

17) L. plantarum glycopeptide $90 \%$, lysozyme $10 \%$;

18) L. helveticus glycopeptide $90 \%$, lysozyme $10 \%$;

19) L. helveticus, foremilk hydrolyzate $95 \%$, lysozyme $5 \%$;

20) pepsin, trypsin, casein hydrolyzate (from milk and colostrum);

21) milk protein polypeptides and lysozyme (from milk and colostrum), betaglucan, lactic acid and L. helveticus glycopeptide;

22) composition GLP 810 (L.helveticus glycopeptide $10 \mathrm{mg}$, lysozyme $300 \mathrm{mg}$, lactic acid $500 \mathrm{mg}$ ).

For all components and compositions, prior to use in vitro and in vivo studies, adding sterile sodium carbonate solution $\left(\mathrm{Na}_{2} \mathrm{CO}_{3}\right)$, the $\mathrm{pH}$ was adjusted to 6.3, which, according to studies (Davies et al., 1969), provides optimum environment and high activity for lysozyme activity.

We used the following control preparations for in vitro studies:

1) Synulox LC (Pfizer Italiana S.R.L., Italy), which is a suspension for intramammary usage for lactating cows, and contains the following active substances: amoxicillin trihydrate, potassium clavulanate and prednisolone;

2) Tetra-Delta (Pfizer Animal Health Ltd., United Kingdom), which also is a suspension for intramammary usage for lactating cows, and contains the following active substances: novobiocin sodium, neomycin sulfate, procaine penicillin, dihydrostreptomycin sulfate and prednisolone;

3) Eurofit gel (Slovenska Yooveterinarna Homeopaticka Spolocnost sro, Slovenia), which is a homeopathic veterinary medicinal product intended for intramammary application in lactating cows, and contains the following active substances: Phytolaca decandra, Hepar, sulfur, Silicea, Sepia officinalis, Thuya occidentalis, Calcarea phosphorica, Pulsatilla, Iodum, Canthar, Phosphorus, Baptisia tinctoria, Echinacea angustifolia, Acidum nitricum, Phellendrum aquaticum, Arnica Montana and Bryonia;

4) $\quad 0.9 \%$ sodium chloride $(\mathrm{NaCl} 0.9 \%)$ solution in water (negative control).

In the next phase of the research, i.e., in vivo studies, we tested the composition GLP 810 and the following ingredients were included in a single dose of this preparation: Lactic acid - $500 \mathrm{mg}$, Lysozyme - $300 \mathrm{mg}$, Glycopeptide - $10 \mathrm{mg}$, and $0.9 \%$ sodium chloride solution in water $-10 \mathrm{~mL}$.

Third phase of the study, during which we carried out a research of immunomodulatory composition GLP 810 in vivo, was conducted from May 26 to June 30, 2015 in one conventional dairy cow farm in Latvia with lactating 
Holstein and Latvian Brown dairy cows as part of routine veterinary medicine practice. The herd consisted of 320 dairy cows housed in tie-stall arrangement and milked twice a day. The sample of the study was subclinically infected cows with somatic cell count (SCC) greater than or equal to 400,000 per $\mathrm{mL}$ in cow composite milk. All the cows included in this study had an increased somatic cell count at least for two consecutive months. The cows which had received treatment with drugs for any reason within 30 days of the treatment start date were excluded from the study. The study sample consisted of 10 multiparous cows with $8,000 \mathrm{~kg}$ average 305 -day yield during the previous lactation. Cows were in their $2^{\text {nd }}$ or $3^{\text {rd }}$ lactation, had been lactating for more than 60 days, and were less than 90 days from their expected dry-off dates. All the cows had no history of concurrent disease other than subclinical mastitis, and had no clinically significant findings. When starting an in vivo research, no cows had any visible visual changes in milk.

\section{Methods}

\section{Sampling, transporting and delivering milk samples obtained in the first stage of the study to the laboratory}

We collected milk samples from the cows's of organic farms for microbiological examination on the same day or within 2 weeks after milk sampling in the milk quality monitoring program. Samples were collected in sterile $6 \mathrm{~mL}$ tubes (Weihai Hongyu Medical Devices Co Ltd., China) by aseptic technique (Bradley et al., 2012) taking one milk sample from each selected cow from all lactation udder quarters together (obtaining composite sample). Although composite sample examinations have high specificity ( $>97 \%$ ), a reduced test sensitivity should be taken into account (Reyher, Dohoo, 2011).

After collection, samples were immediately delivered to the Laboratory of Microbiology at the 'Research Institute of Biotechnology and Veterinary Medicine "Sigra" (Sigulda, Latvia) of Latvia University of Life Sciences and Technology. Samples were transported in a cool bag, keeping the temperature within the range of $4-8{ }^{\circ} \mathrm{C}$. The samples were placed in a freezer at $-20^{\circ} \mathrm{C}$, where we stored them for 2-6 weeks, i.e., until a microbiological examination of the samples was started. By deciding to freeze the samples and carrying out investigations gradually over a period of 2-6 weeks, we relied on studies by the authors (Murdough et al., 1996), who confirm that for storage of milk samples up to 6 weeks $-20{ }^{\circ} \mathrm{C}$, the most commonly used mastitis causative agent (S. aureus, coagulase negative staphylococci, Streptococcus spp., Corynebacterium bovis and E. coli) does not have a significant effect. Other authors (Petzer et al., 2012) stated that a longer period is possible in which mastitis causative agents do not decrease viability: for example, S. agalactiae 12 weeks, E. coli - 16 weeks, and coagulase negative staphylococci (CoNS) 18 weeks). 
Initially four solid growth mediums were inoculated with both the composite milk samples and dilutions (a total of 7560 primary inoculations). The subsequent bacteriological examination was carried out in accordance with the relevant methodology to enumerate bacteria and to identify them. As a result, we obtained $\sim 400$ bacterial isolates, of which seven of the most typical subclinical mastitis causative agents were used in subsequent studies.

\section{Measurements of antibacterial activity of immunomodulators in the second phase of the study}

Measurements of antibacterial activity of the immunomodulators on the growth of the seven strains of mastitis causative bacteria was carried out using the well diffusion technique (Valgas et al., 2007; Tejero-Sariñena, 2012).

The bacterial cultures of $0.1 \mathrm{~mL}$ volume were inserted into sterile $100 \mathrm{~mm}$ Petri plates and poured over with the $20 \mathrm{~mL}$ Miller-Hinton agar (Mueller-Hinton agar, Oxoid, United Kingdom) growth medium, and carefully mixed. Holes of $6 \mathrm{~mm}$ in diameter were cut in agar, and were filled with $60 \mu \mathrm{L}$ of test solution. Plates were prepared in 3 replicates, incubated under aerobic conditions for $24 \mathrm{~h}$ at $37{ }^{\circ} \mathrm{C}$ and the diameter of bacterial clearance or antibacterial activity area was measured. If the diameter of the bacterial clearance zone was less than $0.1 \mathrm{~mm}$, we found that there was no suppression and the tested solution did not have antibacterial activity against the applied bacterial culture. The above-mentioned tests were performed in 3 replicates, analyzing 546 reactions in total.

In total, we used 10 immunomodulatory components, 12 compositions of the components, and 4 control preparations, of which three were of positive control (Synulox LC, Tetra Delta and Eurofit Gel) and one of negative control $(0.9 \% \mathrm{NaCl})$. By placing these immunomodulatory substances and control preparations on a blood-agar growth medium (containing 5\% of cows' blood) and incubating, we examined their sterility and haemolytic activity; we performed these tests in three replicates, analyzing 78 samples in total.

\section{Clinical assessment of cow health status and infusions of intramammary preparations in the third phase of the study}

In the third phase of the study, ten cows were selected, then divided them into two groups of five cows in each. For cows of experimental group (total in 19 quarters) infusions of composition GLP 810 in $10 \mathrm{~mL}$ volume three times at $48 \mathrm{~h}$ intervals (day 1, 3 and 5) were performed. For control cows (total in 19 quarters), in each mammary gland $0.9 \% \mathrm{NaCl}$ solution in volume of $10 \mathrm{~mL}$ three times with a 48 hours interval (day 1, 3 and 5) were administered. Infusions were carried out in the morning after milking from 4:00 to 6:00 a.m. The clinical assessment of cow health status was carried out daily from day 1 to 7 , as well as on the day 14 and day 21, marking the changes in the following parameters: 
1) systemic changes (body temperature, milk yield, appetite);

2) clinical appearance of the mammary glands (redness, hardness, pain, swelling, heat);

3) the visual appearance of the milk (flakes, clots, watery appearance).

Both the control solution and the immunomodulatory composition were infused through the teat canal using individual, single-use teat cannula J-12 (Jorgensen Laboratories, USA) for each mammary gland. Before the infusion, the teat was cleaned with a pad moistened with alcohol, then a four to six streams of milk were drawn and discarded and disinfection was reapeated. After infusion of the solution, we carried out an udder massage in the upward direction, which facilitates the dispersal of the preparation into the mammary gland, as well as the staff member of herd immersed the teats in an iodine disinfectant solution by performing a routine udder hygiene measures.

During the study, milk samples from each mammary gland were taken 5 times, i.e., on day 1 (before the infusion), 3, 5, 7 and 14. We collected blood samples from the tail vein (Latin, vena caudalis mediana) for each cow 4 times, i.e., on day 1 (before the infusion), on day 3, 7 and 21 of the research.

\section{Examination of the samples obtained in the third phase of the study}

In total, at phase three, we obtained 426 milk samples for the study, and then performed the following examinations:

1) conditionally pathogenic microbiota and Lactobacillus spp. analysis samples were collected in sterile tubes; we produced a series of dilutions for the primary quarter milk samples to obtain 570 secondary samples. Then five solid growth medium inoculations with the primary and secondary milk samples were applied to determine the total bacterial count, the enumaration of Streptococcus spp., Staphylococcus spp., Enterobacteriaceae species bacteria, and the presence of E. coli in milk as well as number of Lactobacillus spp. bacteria. Microbiological examinations were carried out at the microbiology laboratory of the Institute of Food and Environmental Hygiene of the LLU VMF;

2) differential counting of somatic cells - samples were collected in sterile centrifugation tubes. Using light microscopy, we performed differential counting of the smears of 137 quarter milk samples to specify the belonging to leukocyte populations. We conducted this investigation at the microbiology laboratory of the Institute of Food and Environmental Hygiene of the LLU VMF;

3) immunohistochemical analysis - a preparation of specimen and placing of milk sediment on glass slides was performed at the microbiology laboratory of the Institute of Food and Environmental Hygiene of the LLU VMF, but a staining of the smears was carried out at the Morphology Laboratory of the Institute of Anatomy and Anthropology at Rīga Stradiňs 
University. The number of expressed cells of inflammatory cytokines IL-1, IL-10, TNF- $\alpha$, antibacterial peptide BD-2 and caspase-6 were determined in 345 quarter milk samples;

4) milk quality studies - samples were collected in sterile laboratory bottles without preservative, and further examination was carried out at Dairy Laboratory Ltd. (Ulbroka, Latvia); for 175 quarter milk samples somatic cell count, total bacterial count, fat content, protein content, lactose content, and $\mathrm{pH}$ were determined.

The number of somatic cells was determined by fluoro-opto-electronic cell counting using a Fossomatic FC (Foss A/S, Denmark) somatic cell counter in accordance with the standard LVS EN ISO 13366-2:2007 'Milk - Enumeration of somatic cells - Part 2: Guidance on the operation of fluoro-opto-electronic counters'.

The determination of the total bacterial count was carried out with the electronic device 'BactoScan FC' (FOSS Electric AS, Germany), which is an automatic bacterial cell counting device based on flow cytometry. The method is validated to control the hygiene quality of the milk.

The determination of fat, lactose and protein content in milk (\%) was carried out using the infrared spectroscopy method in accordance with ISO Standard 9622:1999 'Whole milk. Determination of milk fat, protein and lactose content-Guidance on the operation of mid-infrared instruments.'

The $\mathbf{p H}$ was measured using a $\mathrm{pH}$ meter, the working principle of which is to measure the electrical conductivity of the milk and display the result converted into the corresponding $\mathrm{pH}$ value.

We performed differential somatic cell count according to the methodology described by the authors (Fragkou et al., 2014). A milk sample in $10 \mathrm{~mL}$ amount were removed from mammary glands in sterile centrifugation tubes (volume $10 \mathrm{~mL}$, Plastiques Gosselin, France), subsequently centrifuged at $1500 \times$ rpm for 10 minutes. Using an automatic pipette, we removed the fluid, but approximately $10 \mu \mathrm{L}$ of cell suspension were inoculated on the slide and evenly spread out. The drops were dried at room temperature and stained with Dip Quick stain (Rapid Differential Stain kit) in accordance with the manufacturer's (Astral Diagnostics incorp., USA) instructions. Each smear was examined by light microscopy at 40 and 100 times magnification, counting 100-200 cells and determining their belonging to leukocyte populations: lymphocytes, macrophages and polymorphonuclear leukocytes.

We carried out an immunohistochemical examination of milk to evaluate the expression of inflammatory cytokines interleukin 1 (IL-1) and tumor necrosis factor-alpha (TNF- $\alpha$ ), inflammatory-inhibiting cytokine interleukin 10 (IL-10) and antibacterial peptide beta-defensin 2 (BD-2) expression, as well as apoptosis marker caspase-6, using a customized biotin-streptavidin immunohistochemical method (Hsu et al., 1981). Smears were prepared for the study - from the sediment obtained by centrifuging milk at 
$1500 \mathrm{rpm} \times 10$ minutes. In total, 345 smears prepared from milk samples from 23 mammary glands (19 of experimental and 4 of control group cows) were used for further staining and morphological study at the Morphology Laboratory of the Institute of Anatomy and Anthropology at Rīga Stradinšs University. The following primary antibodies were used for immunohistochemical staining of the smears: rabbit polyclonal IL-1 $\alpha$ (code AB17281, dilution ratio 1:200, Abcam, United Kingdom) and IL-10 (code Ab34843, 1:400, Abcam, United Kingdom), goat polyclonal beta-defensin 2 (code AF2758, 1:100, RD Systems, United Kingdom), rabbit monoclonal caspase-6 (code Ab52951, 1: 250, Abcam, United Kingdom) and rabbit polyclonal tumor necrosis factor alpha (code ab6671, 1:100, Abcam, United Kingdom) and biotin-related secondary antibodies (LSAB+LINK, code K1015, DakoCytomation, Denmark). In the case of a positive reaction, the structures became brown. To avoid artefacts, cell nuclei and backgrounds were stained with hematoxylin (Mayers Hematoxylin, code 05M06002, Bio-Optica, IT).

Analysis of the cow blood samples were taken at the Clinical Immunology Center at the Pauls Stradinš Clinical University Hospital. Blood samples were examined by several methods to determine immunocompetent cell activity, i.e. total number of leukocytes and their populations (segmented and band neutrophils, lymphocytes and monocytes) and lymphocyte population (CD16+, CD19+) and subpopulation (CD4+, CD8+) activity (CD25+, CD45+, CD69+) markers (both the absolute number of these cells in the blood per $\mathrm{mL}$ and their relative quantity). The total number of blood leucocytes was determined with blood cell with 5-part differential haematology analyser (ABX Pentra 60, HORIBA ABX SAS, Japan) according to the standard protocol and differentiation between banded neutrophils, segmented neutrophils and lymphocytes was performed by light microscopy. Peripheral blood mononuclear cells and markers of cell activation were determined using fluorescence-activated cell analysis. CD4+, CD8+, CD14+, CD16+, CD18+,CD19+, CD25+, CD38+, CD69+ and CD95+ cells were detected by a flow cytometer (FACS Calibur, Becton Dickinson, USA) using corresponding mouse antibodies (for example, IgG1 isotope murine monoclonal antibodies, specific for CD4+ and CD8+) according to the manufacturer's protocol.

\section{Microbiological investigation methods used in the first and third stage of the research}

In order to reduce the total number of microorganisms per $\mathrm{mL}$, which would facilitate the growth of microorganisms and colony counting after incubation, milk samples were serially diluted in buffered peptone water (Maximum recovery dilutent, Oxoid, United Kingdom) in accordance with standard LVS EN ISO 6887-5: 2011 'Microbiology of food and animal feeding stuffs. Preparation of test samples, initial suspension and decimal solutions for 
microbiological testing. Part 5: Specific provisions for the preparation of milk and milk products (ISO 6887-5: 2010)'.

The obtained decimal dilution series of $10^{-2}$ to $10^{-5}$ as well as the primary sample (undiluted milk) were applied to the following mediums:

1) in the 1st stage of the study, on Blood agar (Blood agar base, Oxoid, UK with sterile cow blood $50 \mathrm{~g} \mathrm{~L}^{-1}$ ), Baird Parker agar (Baird Parker agar with egg yolk supplement, Biolife Italiana, Italy), Violet Red Bile Glucose Agar (VRBG, Oxoid, UK) and Milk Agar (Oxoid, UK);

2) in the 3rd stage of the study, on Blood agar, Baird Parker Agar, VRBG, Tryptone Bile X-Glucuronide medium (TBX Agar, Oxoid, UK) and De Man, Rogosa, Sharpe Agar (MRS, Oxoid, UK).

In order to determine the total bacterial count in milk samples from organic herds, obtained in the first stage of the study, we used milk agar (Oxoid, United Kingdom) according to standard LVS 179:1999 'Milk and milk products - Determination of the number of colony-forming units of microorganisms Colony counting technique at $30^{\circ} \mathrm{C}$ '.

Baird Parker agar with egg yolk supplement (Biolife, Italia) for the enumeration of staphylococci was used in accordance with the standard LVS EN ISO 6888-1: 1999/A1:2003 'Microbiology of food and animal feeding stuffs - Horizontal method for the enumeration of coagulase-positive staphylococci (S. aureus and other species) - Part 1: Technique using BairdParker agar medium - Amendment 1: Inclusion of precision data'. We confirmed the identification of $\boldsymbol{S}$. aureus with the diagnostic reagent 'Staphytect Plus' (Oxoid, UK), where a positive reaction (confirmed $S$. aureus), according to the manufacturer's instructions, is the formation of macroscopically visible flakes. For isolates of coagulase negative staphylococci, identification was carried out to a species level using BBL Crystal Gram-positive ID (Becton, Dickinson and Company, USA) and MALDI Biotyper (Bruker, Germany).

The enumeration of bacteria of the family Enterobacteriaceae was carried out on pour plate technique on Violet Red Bile Glucose agar (VRBG, Biolife, Italia) in accordance with the standard LVS ISO 21528-2:2007 'Microbiology of food and animal feeding stuffs - Horizontal methods for the detection and enumeration of Enterobacteriaceae - Part 2: Colony-count method'. E. coli detection was carried out in accordance with previously described technique (Leininger, Roberson, Elvinger, 2001).

Blood agar (contain 5\% bovine blood) was used for isolating Streptococcus and Enterococcus spp. following UK Standards for Microbiology Investigations (UK Standards..., 2014). After incubation for $24 \mathrm{~h}$ at $37^{\circ} \mathrm{C}$, we counted colonies typical of streptococci and used bile esculin agar (Bile aesculine agar, Oxoid, Great Britain) and catalase test for confirmation. All cultures that were catalase-negative and formed a black or yellow-brown coloration were confirmed as Group D streptococci - Enterococcus spp. For those cultures that did not belong to Enterococcus spp. but had catalase negative and caused beta- 
haemolysis on blood agar, were performed by the PathoDxtra Strep Grouping Kit for the Lancifield group (A, B, C, D, F, G) Streptococcus spp. identification according to manufacturer's instructions (Oxoid, UK).

We performed the determination of lactic acid bacteria (Lactobacillus spp.) using de Man, Rogosa, Sharpe agar (MRS, Oxoid, Great Britain) according to the method described by the authors (Leininger et al., 2001). This method is based on the requirements of standard ISO 15214: 1998 'Microbiology of food and animal feeding stuffs - Horizontal method for determination of mesophilic lactic acid bacteria - Colony count method at $30^{\circ} \mathrm{C}$ '.

In the case of obscure situations, the bacterial cultures were identified using the BBL Crystal test (Becton, Dickinson and Company, USA) - the Grampositive and Gram-negative bacteria identification system, which included fermentation, oxidation and hydrolysis tests for several substrates, but the identification is done by comparing the results obtained with the database.

\section{Statistical analysis}

The data on the somatic cell count (SCC) in cows in the first stage of the study were obtained from the state institution Agricultural Data Centre, but in stages 3 and 4, we determined the SCC in our collected milk samples. Data analysis uses categorization of the udder quarters in the following groups: normal secretion, disturbed secretion, latent infection and mastitis according to the International Dairy Federation (IDF) guidelines, and in this case the limit value is $200 \times 10^{-3}$ cells $\mathrm{mL}^{-1}$ of a composite milk sample (Pyorala, 2003).

In turn, in order to analyze the compliance of cow milk with the food quality requirements laid down in Regulation (EC) No. 853/2004 of 29 April 2004 of laying down specific hygiene rules for food of animal origin, we have applied a threshold of $400 \times 10^{-3}$ cells $\mathrm{mL}^{-1}$ for SCC and threshold of $100 \times 10^{-3} \mathrm{cfu} \mathrm{mL}^{-1}$ for a total bacterial count in raw cow milk.

Published data is used as the basis for acceptable physiological values of blood morphological indicators (Wood, Quiroz-Roch, 2010).

Results were expressed as average \pm standard error. Comparisons of the dynamics of mean parameters were performed by the Wilcoxon Signed Ranks two-sample test. The Mann-Whitney U test was used for comparisons between GLP 810 and control group parameters.

We also used Chi-Square test for independence to assess whether two variables differ from each another. The Cramer's V test allowed us to assess the strength and relevance of the relationship between two features that did not fit the normal distribution or between two scale variables. In contrast, we used the Kendall's (Kendall's tau-b) correlation coefficient to measure the relationship between two ordinal variables (Arhipova, Bāliņa, 2003; Paura, Arhipova, 2002).

For assesment of the expression of inflammatory cytokines, antibacterial peptide and apoptosis marker we used the semi-quantitative counting method for a relative quantity of positive structures (Pilmane et al., 1998). The positive 
structures according to their quantity into immunoreactive cells were divided into several groups: (-) - negative, $(+)$ - few, $(++)$ - average and $(+++)$ - a lot of positive structures. To compare distribution of results obtained by means of immunohistochemical methods, a relative frequency calculation model was used (Goša, 2003).

Statistical significance was set at $p<0.05$ for all statistical analyses. Statistically high significancy is when $p<0.001$ or less.

\section{RESEARCH RESULTS AND DISCUSSION}

\section{Distribution of microorganisms in bovine milk from organic farming in Latvia}

Microorganisms in the milk are an extensively studied topic. Scientists have come to the conclusion that milk contains a wide spectrum of microorganisms (Rainard, 2017), including lactic acid bacteria, butyric acid bacteria, putrific bacteria, coliforms, yeasts and molds, as well as pathogenic and conditionally pathogenic bacteria.

The first objective of the study was to investigate the bacterial diversity of cow milk in organic herds in Latvia and their seasonal dynamics. In the first stage of the study, we analyzed the microbiological contamination of cow milk in 14 organic herds in Latvia. The dynamics of somatic cell count (SCC) in the examined cow milk was assessed using monthly monitoring data.

\subsection{Total bacterial count}

Bacteria of milk, that are in large numbers and in a great variety, form the natural microbiota of the product (Rainard, 2017), and binding legislation (EC 853/2004) determines that up to $100 \mathrm{cfu} \times 10^{-3} \mathrm{cfu} \mathrm{mL}^{-1}$ in raw milk is a quantity suitable for high quality and safe milk. If the total bacterial count (TBC) is higher, in most cases it is due to inappropriate complying with sanitaryhygienic norms, but sometimes also suggests an intramammary infection, i.e., mastitis (Murphy, Boor, 2000).

Variation in the total bacterial count in milk can be very wide. In our investigated milk, TBC was on average $43 \pm 5 \mathrm{cfu} \times 10^{-3} \mathrm{~mL}^{-1}$. The authors Torkar and Teger (2008) have found that the total bacterial count was higher than $100000 \mathrm{cfu} \times 10^{-3} \mathrm{~mL}^{-1}$ in $23.6 \%$ out of raw milk samples, and these observations are similar to ours.

We investigated that in organic farms, $84.2 \%$ of milk samples were low in TBC meeting milk quality requirements (up to $100 \mathrm{cfu} \times 10^{-3} \mathrm{~mL}^{-1}$ ), but in $15.8 \%$ of samples TBC was high (over $100 \mathrm{cfu} \times 10^{-3} \mathrm{~mL}^{-1}$ ). The results acquired to meet the data from other studies on organic dairy farming in Latvia that have 
found $27 \%$ presence in milk that did not meet the total bacterial count requirements (Zagorska, 2007).

There is little information in the literature on how the size of a herd could directly affect the distribution of microorganisms in milk, but it has been proven that the herd size has an effect on total microbial contamination in milk, most likely due to different management approaches (Jayarao et al., 2004; Cempirkova, 2006; Coorevits et al., 2008; Archera et al., 2013).

We found out that there is a significant correlation between the herd size and bacterial count in milk (Fig. 1). We observed the highest levels of bacteria in milk in large herds (C), where the mean number of TBC was $179.8 \pm 34.8 \mathrm{cfu} \times 10^{-3} \mathrm{~mL}^{-1}$. Lower TBC was in the small (A) herds, i.e., an average of $47.7 \pm 12.2 \mathrm{cfu} \times 10^{-3} \mathrm{~mL}^{-1}$, but the smallest number of bacteria was found in medium size (B) herds, i.e., an average of $31.0 \pm 5.0 \mathrm{cfu} \times 10^{-3} \mathrm{~mL}^{-1}$.

Samples that do not meet the raw milk quality requirements, i.e., when the amount of TBC in milk exceeded $100 \mathrm{cfu} \times 10^{-3} \mathrm{~mL}^{-1}$, most often we found in large (C) herds (23.8\%), but in other herds less commonly - in the A herd group $12.8 \%$ and in the B herds $-8.2 \%$ of the examined milk samples.

It is commonly found in literature that seasonal climate variations have a significant effect on the microbiological composition of milk (Osteras et al., 2006; Olde Riekerink et al., 2007; Nobrega, Langoni, 2011; Zucali et al., 2011). In order to evaluate changes in the bacteriological contamination of the milk depending on the season, we analyzed the results obtained in winter, spring, summer and autumn.

We found that the milk sampling period significantly impacted the TBC in milk but not the prevalence of conditionally pathogenic bacteria, with the exception of coagulase negative staphylococci (CoNS), since in autumn these bacteria were found more often (54.3\% of samples) than in other seasons $(17.0 \%-32.1 \%$ of the sample).

As shown in Figure 2, the highest mean TBC was from the samples obtained in autumn $\left(243 \pm 644 \mathrm{cfu} \times 10^{-3} \mathrm{~mL}^{-1}\right)$, while in other seasons the bacterial contamination of milk was significantly lower $\left(72 \pm 11 \mathrm{cfu} \times 10^{-3} \mathrm{~mL}^{-1}\right.$ in winter, $57 \pm 16$ cfu $\times 10^{-3} \mathrm{~mL}^{-1}$ in spring and in summer $\left.24 \pm 11 \mathrm{cfu} \times 10^{-3} \mathrm{~mL}^{-1}\right)(p=0.000)$.

We also found that the milk obtained in autumn and winter doesn't often meet the milk quality requirements constituted as $21.0 \%$ and $20.6 \%$ of investigated samples, respectively (whereas in spring and summer the number of non-conforming samples was $11.9 \%$ and $8.3 \%$, respectively).

Elmoslemany with his team of authors (2010), has suggested that seasonal changes in the microbiota of milk are caused not only by air temperature and humidity, but also by the characteristics of livestock production management, which include a sanitary hygiene in the holding and pasture. It is possible that the high contamination with bacteria in milk obtained in winter and autumn from our surveyed farms was related to the deterioration of sanitary 
conditions in the holding and pasture due to the indoor period and inadequate hygiene in the cow-shed and also due to the moisture that prevailed in autumn.

\subsection{Bacteria isolated from milk samples}

From the point of view of food safety and quality, the presence of bacteria in milk results in three major problems: the presence of microbial toxins, the formation of biofilms, and the presence of undesirable enzymes in milk (Pukančikova et al., 2016). In addition, many of the bacteria found in healthy cows' mammary glands can, under certain conditions, be able to initiate mastitis. The second objective of our study was to find out the prevalent subclinical mastitis causing bacteria.

Within the research, prevalent microorganisms were CoNS 30.9\%, S. aureus $25.2 \%$, microorganisms of genus Enterobacteriaceae $13.7 \%$ and K. kristinae $13.1 \%$ of the 540 analyzed milk samples. Micrococcus spp. (7.0\%), Corynebacterium spp. (5.4\%), Streptococcus spp. (4.6\%) and Bacillus spp. $(4.3 \%)$ were uncommonly isolated. Other microorganisms constituted $11.9 \%$, while $5.6 \%$ of samples were culture negative.

It is known that the type / species of invading bacteria has a significant effect on the total bacterial count and somatic cell count in milk. Many authors have found a significant correlation between SCC and udder health, with SCC greater than $200 \mathrm{cfu} \times 10^{-3} \mathrm{~mL}^{-1}$ indicates the case of disturbed secretion or mastitis (Dohoo, Leslie, 1991; Schepers et al., 1997; Moretti et al., 1998). The main agents (e.g. S. aureus, Str. agalactiae and coliforms) cause a significantly higher increase in the number of somatic cells than minor agents of mastitis (e.g. Corynebacterium bovis and CoNS) (Souza et al., 2016; Kociņa, 2011; Oikonomou et al., 2014). In accordance with criteria defined in the EC Regulation No 853/2004, the permitted somatic cell count in raw milk is up to 400 cells $x 10^{-3} \mathrm{~mL}^{-1}$.

Within the research (see Fig. 3) S. aureus with $739 \pm 96$ cells $\times 10^{-3} \mathrm{~mL}^{-1}$, Corynebacterium spp. with $1059 \pm 464$ cells $\times 10^{-3} \mathrm{~mL}^{-1}$ and $S$. aureus in association with Enterobacteriaceae $\left(1607 \pm 405\right.$ cells $\left.\times 10^{-3} \mathrm{~mL}^{-1}\right)$ caused the most severe increase in SCC in milk.

SCC did not exceed 200 cells $\times 10^{-3} \mathrm{~mL}^{-1}$ in milk samples with Micrococcus spp. or negative bacteriology, which corresponds to the healthy mammary gland, although.

Many researchers have identified that the level of microbial contamination of raw milk is influenced by the health and cleanliness of the cows, the cleanliness of the environment in which the cows are kept and milked, including the method of preparing the udder before milking, milking technology, milking equipment and milk tank cleaning and disinfection methods, cooling rate and milk storage time (Oleggini et al., 2001; Jayarao et al., 2004; Cempirkova, 2006; Coorevits et al., 2008; Vacheyrou et al., 2011; Mallet et al., 2012). In one word, all these important factors can be called dairy management. 
Our obtained results on microorganisms in milk suggest that in Latvian organic livestocking, dairy management are is more successfully realized in herds consisting from 31 to 60 lactating cows, that is, medium size herds, as evidenced

(1) the smallest total bacterial count (on average $31.0 \pm 5.0 \mathrm{cfu} \times 10^{-3} \mathrm{~mL}^{-1}$ ), (2) a small number of not beeing in compliance with the microbiological quality requirements $(8.2 \%)$, (3) a significantly lower mean somatic cell count $\left(349 \pm 48\right.$ cells $\left.\times 10^{-3} \mathrm{~mL}^{-1}\right)$ than in small and large herds, (4) and significantly lower prevalence of coliform bacteria (11.1\%) than in milk obtained from large herds.

\section{Evaluation of immunomodulator components and compositions antibacterial activity in vitro conditions}

One of the prospecting approaches in the treatment of infectious diseases is immunomodulation. In the context of animal health, immunomodulation is defined as the ability to improve an animal's resistance to infectious agents and stress factors in order to promote animal productivity. Substances used in immunomodulation are called immunomodulators (Dhama et al., 2015).

Cow milk contains many immunologically active substances with antibacterial activity, but some of the most important are lysozyme and lactoferrin (Lucarini, 2017). Over the last couple of decades, the therapeutic effects of immunomodulators have been widely studied and the results suggest that the systemic initiation of immune reactivity of this type could prevent the converting of subclinical mastitis cases into clinical forms or even promote mammary gland healing.

Taking into account the results obtained in the first stage of the study, that the prevalent organisms in raw dairy cow milk of organic production were coagulase negative staphylococci, $S$. aureus, microorganisms of the family Enterobacteriaceae and $K$. kristinae. The incidence of these agents in the milk was associated with elevated SCC and we used these pure cultures, to further evaluate the antibacterial activity of immunomodulator components and compositions in vitro conditions. The one of these compositions we used for treating the subclinical mastitis in cows (see 1. Tab.).

Evaluating the antagonistic effect of individual components of natural substances on mastitis causative agents, as shown in Table 1, the highest antibacterial activity in vitro was demonstrated by lysozyme (15.0 to $19.5 \mathrm{~mm}$ ), lactic acid ( 8.3 to $24.3 \mathrm{~mm}$ ) and lactoferrin $(8.0$ to $11.0 \mathrm{~mm})$. All these are immunologically active substances originating from lactic acid bacteria, so these components that are naturally present in cow milk were also used later to develop an immunomodulatory composition for controlling mastitis in cows.

It is known that lysozyme, acting alone, lyses the main component of the gram-positive bacterial cell wall - peptidoglycan, causing cell death. Due to this 
fact it is possible to observe lysozyme's antibacterial activity in vitro (Lawrence, Pane, 2007). By contrast, Gram-negative microorganisms are more resistant to the destructive effect of lysozyme, since their cell walls contain about five times less peptidoglycans but are protected by lipid and mucus layer (Lawrence, Pane, 2007). The antibacterial effect of our tested lysozyme was to a similar degree both in Gram-positive (18.5-19.5 mm) and Gram-negative bacteria cultures $(18-20 \mathrm{~mm})$, but the lower growth inhibition zone had Citrobacter freundii $(15.0 \mathrm{~mm})$ (see Table 1).

The basis for antimicrobial action of lactoferrin is, firstly, the ability to bind iron, making it inaccessible to pathogenic bacteria, while promoting the growth of beneficial bacteria. Secondly, lactoferrin causes damage to the Gramnegative bacterial cell walls (Kutila et al., 2003; Panwar, 2014). We tested two types of lactoferrin, i.e., RSU colleagues isolated lactoferrin from colostrum and lactoferrin manufactured industrially in Germany. Lactoferrin isolated from colostrum showed antibacterial activity (10 $\mathrm{mm}$ growth inhibition zone) only against two cultures and both were Gram-positive bacteria, i.e., the small colony variant $S$. aureus and $S$. haemolyticus. Lactoferrin purchased from Germany showed moderate antagonistic activity against all tested mastitis causing bacteria ( 8 to $11 \mathrm{~mm}$ in diameter) (see Table 1 ).

Lactic acid is an antimicrobial metabolite produced by lactic acid bacteria that destroys many pathogenic bacteria or at least inhibit their growth. The basis of the antibacterial effect is the reduction of $\mathrm{pH}$ (Widyastuti et al., 2014). Nevertheless, as shown in Table 1, we observed that lactic acid with neutralized $\mathrm{pH}$ still has a high antagonistic effect on the growth of all seven tested pathogenic bacteria (an average of $15.6 \mathrm{~mm}$ growth inhibition zone).

Medicinal plants play vital roles in disease prevention and treatment. In recent years an active research is beeing carried out on medicinal herbs with an aim to identify their potential effect in the treatment of infectious diseases in animals. There are studies that report phytotherapeutic product great immunomodulating potential, which can achieve effective improvement and even a complete recovery in both clinical and subclinical mastitis cases (Abaineh, Sintayehu, 2001; Verma, Nauriyal, 2009; Umadevi, Umakanthan, 2010).

We tested broadleaf plantain (Lat., Plantago major) exctract of their leaves and chamomile (Lat., Matricaria recutita) extract. We obtained the results that the extract of broadleaf plantain had a low antibacterial activity, which was limited to one of the microorganisms, the small colonie variant $S$. aureus. The extract of chamomile yielded the highest antagonistic activity against S. saprophyticus $(12 \mathrm{~mm})$.

Further we tested the antibacterial activity of several compositions (see Table 2). The composition consisting of milk casein and glycopeptide exhibited a low antagonistic activity against $E$. coli growth $(8.0 \mathrm{~mm})$, but a composition consisting of lysozyme and glycopeptide - against $S$. aureus typical strain $(9 \mathrm{~mm})$ and $S$. haemolyticus $(8 \mathrm{~mm})$. 
The composition containing lysozyme, lactoferrin, lactic acid and L. helveticus glycopeptide yielded an average growth inhibition zone of $15.6 \mathrm{~mm}$. An even greater antibacterial activity was observed in a similar composition supplemented with a concentrate of broadleaf plantain, i.e., an average of $19.1 \mathrm{~mm}$.

Our tested composition GLP 810 containing substances with the most antibacterial activity, i.e., lysozyme and lactic acid, in combination with L. helveticus glycopeptide, showed antagonistic effects on both strains of $S$. aureus and also against $E$. coli, from 9.0 to $15.0 \mathrm{~mm}$ high growth inhibition. We chose the composition GLP 810 as the optimal for testing the newly created immunomodulator with antibacterial effects under in vivo conditions.

At the bases of the effect of any medicinal substance is its haemolytic activity and sterility, which is why we performed tests for the hemolytic activity of components and compositions. After $24 \mathrm{~h}$ incubation at $37{ }^{\circ} \mathrm{C}$, none of our tested immunomodulator components and compositions caused haemolysis in the blood agar, or the growth of the microorganisms on the blood agar formed, therefore they were found suitable for intramammary administration.

\section{Immunomodulatory activity in vivo condition}

In the second phase of the study, we found that the substances that showed the highest antibacterial activity in vitro were lysozyme, lactic acid and lactoferrin. We selected the composition GLP 810 containing lysozyme and lactic acid in combination with the glycopeptide of $L$. helveticus as the most suitable choise to carry out an in vivo examination of the newly created immunomodulator with an antibacterial effect in cows with subclinical mastitis.

\subsection{Mastitis causing bacteria in milk}

One of the important characteristics of an immunomodulators that allows it to be used for the prevention and treatment of infectious diseases is its antagonistic impact on the growth of pathogenic bacteria, at the same time not inducing an adverse effect on the beneficial microbiota (Banos et al., 2013). In vivo studies, antibacterial activity of lysozyme and lactic acid has been well documented as part of non-specific innate immunity (Brul, Coote, 1999; Benkerroum, 2008; Ella et al., 2011; Espeche et al., 2012).

During the in vivo study, we observed that after infusions the number of pathogen-free mammary glands significantly increased (from 3 to 11) in the experimental group but the number of pathogenic bacteria in milk samples significantly decreased to about $87 \%$ (from $51 \pm 29$ to $7 \pm 4 \mathrm{cfu} \times 10^{3} \mathrm{~mL}^{-1}$ ) on day 3 and by $92 \%$ (to $4 \pm 2$ thousands cfu $\times 10^{3} \mathrm{~mL}^{-1}$ ) on day $7(p<0.01$ ), as shown in Figure 4. 
Unfortunately, although the number of infected mammary glands was the same in both study groups $(n=7)$, the number of pathogenic bacteria in the control group milk was four times lower, i.e., $13 \pm 6 \mathrm{cfu} \times 10^{3} \mathrm{~mL}^{-1}$ (not a significant difference, $p>0.05$ ) than in the GLP 810 study group, which reduces significance of observations.

We found out that intramammary infusion of composition GLP 810 significantly decreased (by 97\%) the number of mastitis causing bacteria only in initially infected quarters with high SCC $(p<0.05)$. While the dynamics of mastitis causing bacteria count did not changed remarkably $(p>0.05)$ in initially low SCC and control quarters .

Besides studies performed by other researchers aiming at finding out in vivo activity in dairy cows of probiotics and bioactive peptide resulted in discovering that the presence of pathogenic microorganisms in mammary glands had diminished due to the regulation of the innate immune system and high antibacterial activity against pathogens (Frola et al., 2012; Cao et al., 2007; Kai et al., 2002).

Analyzing all milk samples from the study on day $1(n=38)$, we found that if the number of pathogenic bacteria in milk exceeds $100 \mathrm{cfu} \times 10^{3} \mathrm{~mL}^{-1}$, the mastitis occures in all $(100 \%)$ of these cases $(p<0.01$, Kendall coefficient 0.425$)$.

\subsection{Evaluation of milk quality indicators}

To evaluate the effect of immunomodulators on the quality of milk, we analyzed the dynamics of somatic cell count and total bacterial count and the amount of nutritional content (fat, lactose and protein) prior to the administration of the compositions and during the treatment. We also determined the $\mathrm{pH}$ of the milk.

Figure 5 shows a rapid increase in somatic cell count in the experimental group milk in 48 hours after GLP 810 1st and 3rd infusion (from $1.6 \pm 0.8$ million cells $\mathrm{mL}^{-1}$ to $4.8 \pm 0.6$ million and 3.3 million cells $\mathrm{mL}^{-1}$, respectively), but on day 14 of the study SCC did not significantly differ from the baseline.

We found out that intramammary infusion with GLP 810 elevated quarter milk SCC mainly because of an increase in SCC of initially uninfected quarters with low SCC $(p<0.01)$. This observation is similar in other studies about intramammary application of bioactive preparations of Lactobacillus origin in cows (Ryan et al., 1999). While SCC dynamics in the control group mammary glands was statistically insignificant throughout the study period, with the exception of day 5 , when SCC lightly but statistically significantly increased from $0.8 \pm 0.3$ million cells $\mathrm{mL}^{-1}$ to $1.3 \pm 0.5$ million cells $\mathrm{mL}^{-1}$.

Our observations are partially supported by the findings of other authors that $0.9 \% \mathrm{NaCl}$ infusion does not lead to a significant increase in quarter milk SCC (Wellnitz et al., 2014). On the contrary, administration of substances with immunomodulatory properties such as TNF (Watanabe et al., 2000), 
recombinant bovine CD14 protein (Erskine et al., 2004) and lactoferrin (Kai et al., 2002) causes a rapid somatic cell influx in the mammary gland.

The authors (Watanabe et al., 2000; Stefanov, Petrovski, 2006; Ogola et al., 2007; Alnakip et al., 2014) state that high SCC in milk is predominantly because of influx of neutrophil leukocytes to mammary gland, moreover, activated neutrophil leukocyte realize phagocytosis of pathogenic bacteria and produce reactive oxygen molecules and antibacterial peptides serving as the first defence line in the fight against infection. The activity of leukocytes may result in decreased milk synthesis and the amount of milk specific ingredients, as well as increased enzymatic activity of the milk, which is destructive to milk proteins and fats.

However, our observations did not confirm either the loss of milk synthesis or the decrease in the amount of milk components after the infusion of preparations, except for the amount of lactose. The amount of lactose in the milk of GLP 810 study group significantly decreased from $4.7 \%$ on day 1 to $4.1 \%$ on day 3 while on day 7 of the study the content of lactose was still significantly reduced $(p<0.001)$, i.e., by $4.2 \%$ (see Fig. 6 ).

The protein content of milk after infusions did not change significantly (in the experimental group cow milk 3.7-3.8\% and significantly lower in the control group cow milk, i.e., by $3.4 \%$ ). The fat content of the cow milk of the experimental group on day 3 was significantly increased (from $1.6 \%$ to $2.4 \%$ ) but in the control group - without significant changes (1.7-2.1\%) (see Fig. 6).

Considering that infusions of the composition GLP 810 did not lead to a destruction of nutrients in milk, we conclude that infiltration of neutrophile leukocytes in the mammary gland tissues has gone under controlled intensity.

\subsection{The bovine health and changes in the milk consistency}

During the study, we did not find any deterioration in the clinical condition of cows (including body temperature, milk yield, appetite), and the clinical state of mammary glands were without pathological changes (such as swelling, heat, hardness, redness, or pain). However, after initiation of the infusion of the test solutions, visual changes in the milk consistency (a small number of flakes or clots) were observed. The changes in the milk consistency were found significantly more often in the milk obtained from experimental group cows from day 3 to day 6 of the study.

We found that the formation of flakes and clots was significantly influenced by the milk $\mathrm{pH}(p<0.005)$, because they were observed only in cows whose milk samples had a $\mathrm{pH}$ of 6.40-6.52, that is, lower than the average in the group. In addition, the changes in this milk consistency were probably due to increased activity of leukocytes in milk, as clots and flakes were observed almost exclusively in milk samples (19 out of 20) in which the SCC exceeded $200 \times 10^{3}$ cells $\mathrm{mL}^{-1}(p=0.000)$. 
Clots in milk are usually the result of a degradation of the cellular structure of casein. The authors (Guo, Wang, 2016) report that casein loses its stability when the milk pH is at $\mathrm{pH} 4.6$ or lower. However, our results do not confirm this possibility, since $\mathrm{pH}$ in any of the analyzed milk samples was not lower than 6.2 , while the protein content of milk did not change substantially during the study. It is possible that the formation of clots and flakes following the administration of the composition GLP 810 into mammary glands has led to somatic cell-derived proteases that can cause hydrolysis of beta casein and subsequent proteolysis ( $\mathrm{Li}$ et al., 2014). In this case, however, the activity of proteases in the milk glands during the study has been low because it was observed focally.

\subsection{Leukocyte dynamics in milk and blood}

Leukocytes are immune cells that perform diverse functions and are divided into granulocytes (or polymorphonuclear leukocytes, PMNL) and agranulocytes (lymphocytes and monocytes / macrophages). The part of leukocytes is permanently present in the mammary gland environment as they aid in the restructuring of the udder tissue during involution (i.e., apoptosis) or after inflammation, and also provides immediate immune response in case of invasion of pathogenic bacteria (Alnakip et al., 2014).

In order to evaluate the effect of the immunomodulatory composition GLP 810 on the functional state of the bovine immune system in the bovine peripheral blood and locally in the mammary glands, we evaluated the number of leukocyte and their populations, and lymphocyte subpopulation surface CD markers. We have also evaluated the leukocyte dynamics between the peripheral bloodstream and the mammary gland.

PMNL are the first recruited immune cells from blood to sites of infection in mammary gland. The migration of PMNL during intramammary infection results in an increase of SCC with the aim to phagocytose bacteria, to produce molecules of reactive oxygen and antimicrobial peptides capable to eliminate broad spectrum of mastitis causing bacteria (Oviedo-Boyso et al., 2007). Most of PMNL, both the circulating and the persistent in a mammary gland, are functionally mature segmented leukocytes.

As shown in Table 3, the absolute number of segmented leukocytes in the cow blood of the GLP 810 group didn't change significantly and fell within the physiological norm throughout the study period. On the other hand, the absolute number of segmented leukocytes in the cow blood of the control group had a significant increase on day 3 of the study (from $1.8 \pm 0.3 \times 10^{6}$ to $4.5 \pm 1.1 \times 10^{6} \mathrm{~mL}^{-1}$ ) exceeding the physiological norm.

In the milk, as shown in Fig. 7, significant increase in the number of PMNL occured both in the milk of the experimental (about 56-63\%, $\mathrm{p}=0.000$ ) and the control group (about 45-63\%, $p<0.05$ ) following intramammary infusions with GLP 810 or $0.9 \%$, respectively. In the experimental group 
mammary glands, the increase in PMNL count continued till day 14 and probably longer, while in the control group the number of PMNL was decreased on day 14 , not significantly differing from the baseline.

The interaction of PMNL between peripheral blood and milk is indicative of the leukocyte compensated proliferation in the mammary glands of the experimental cow group, which lasted from day 3 to day 21 in the peripheral blood and from day 3 to day 14 of the study in the mammary gland tissues. Whereas, after infusion of the control solution, a short-term (from day 3 to day 7) inflammatory reaction occured in mammary glands with subsequent prolonged proliferation of PMNL in the cow blood (from day 3 to day 21) of the control group.

Lymphocytes play a major role in a host immune response as they are the only cells that recognize antigens, using specific membrane receptors and subsequently they produce antibodies (Sordillo et al., 1997). According to the authors (Banos et al., 2013), the reduction in the number of lymphocytes in the cow blood makes them more susceptible to the infection, and this condition occurs simultaneously with a proportional increase in the number of inflammatory cells (including macrophages, neutrophils and natural killer cells).

As shown in Table 4, the number of lymphocytes in the cow blood of the experimental group on day 7 showed a tendency of decrease when the mean absolute lymphocyte count was below the physiological norm. The relative amount of lymphocytes on day 7 was also at its lowest point, which was significantly lower than on day 1.

In the cow blood samples of the control group, the absolute number of lymphocytes during the study displayed no significant dynamics, but the percentage of lymphocytes showed a tendency of decrease. Furthermore, on day 21 , the amount $(\%)$ of lymphocytes in the cow blood of the control group blood was significantly lower than in the baseline (see Table 4).

As shown in Fig. 3b, in the cow milk the number of lymphocytes increased significantly in the cows of the experimental group $(p=0.000, p<0.001)$ after the start of GLP 810 infusions which suggests a short-term noncompensated lymphocyte migration from the peripheral blood to the mammary gland. Changes in the lymphocyte count in the control group mammary glands were statistically insignificant $(p>0.05)$.

Various surface markers become expressed during the activation of immune cells; some are involved in cell proliferation and in signal transduction, some become as indicators of cell maturation, some reflect a capacity of functional activity (Gulbe et al., 2017).

As shown in Fig. 9, the dynamics of the lymphocyte count observed during the study correlated with changes in the number of CD45+ cells in the blood, which is a marker of the T cell blastogenesis (Rivas et al., 2002).

An increase in the absolute number of the CD45+ cells, since day 3 to day 21 the amount of this marker in the cow blood of the experimental group was 
significantly higher than in the cow blood of the control group (32-66\%), suggesting that after the administration of the composition GLP 810 in the mammary glands the $\mathrm{T}$ lymphocyte migration from the peripheral blood to tissue has occurred.

Analyzing the dynamics of lymphocyte count in blood and milk, it can be concluded that an increase in the activity of individual lymphocyte subpopulations and a suppression of other subpopulations have occured after the GLP 810 infusions. Hence it must be assumed that the mammary gland has undergone lymphocyte migration, which mainly affected the number of $\alpha \beta$ cells, as evidenced by the decrease in the absolute number of CD4+ cells observed on days 3 and 7 in the experimental cow blood (Fig. 10 (A)), and the trend towards a decrease in the absolute number of CD8+ cells that we detected on day 7 (Fig. 11 (A)).

At the same time, the relative number of $\mathrm{CD} 4+$ cells increased significantly on day 7 (Fig. 10 (B)), possibly at the expense of other lymphocyte populations, indicated by a significant decrease in the relative number of CD16+ cells which are the marker of natural killer cells (NK cells). T helpers (CD4+) are the major promoters of the acquired immunity response, and they may have been involved in the acute inflammation initiation in the udder, which continued till day 7 of the research (i.e. $48 \mathrm{~h}$ after the last infusion).

In contrast, CD8+ cells or T-suppressors which are a cytotoxic $\mathrm{T}$ lymphocyte markers, have very likely been used to suppress inflammation since research day 7, as evidenced by the decrease in the above mentioned CD8+ cell count on the 7th day. On day 21 of the study, the absolute number of CD8+ cells in the cow blood samples of the experimental group was significantly higher (by 76\%) than in the blood samples of the control group (see Figure 11 (A)).

Thereby, on day 3 of the study, we detected a decrease in the number of CD4+ cells (T-helpers) and a relatively constant number of CD8+ cells (T-suppressors and T-cytotoxic lymphocytes), and as a result the immunoregulatory index in the cow blood of the experimental group decreased (from 2.4 to 1.2 ).

If the the CD4/CD8 index of less than one, a low immunity and a high susceptibility to mastitis occures. The long-lasting low CD4/CD8 index often indicates a suppressed immunity and a chronic, subclinical infection (Park et al., 2004; Alnakip et al., 2014). The decrease of the immunoregulatory index in our study, on the contrary, as shown in Fig. 12, was temporary in the cow blood of the experimental group, since we observed it only on day 3 . Whereas on day 7 , the index was equal to the baseline associated with a significant decrease in the total lymphocyte count in cow blood, which we observed on the same day. On day 21 , the CD4/CD8 index of the experimental cow blood had significantly decreased from the initial 2.4 to 1.8 due to the tendency of increasing CD8+ cell count (which was statistically insignificant) (see Fig. 12).

We observed that the amount of NK cells in the experimental cow blood decreased significantly (by about $80 \%$ ) only 2 days after the last application of 
the composition (on day 7), which suggests that the acquired immunity to the immunomodulatory composition GLP 810 in the mammary gland reacts more slowly than the $\mathrm{T}$ lymphocytes which represent the innate immunity.

It was reported that NK cells can modulate adaptive immune responses via an early production of cytokines (from $\mathrm{T}$ helper type 1 ) or an interaction with antigen presenting cells (Banos et al., 2013). We suppose that the NK attempted to boost the function of the $\mathrm{T}$ arm of the adaptive immune system in the peripheral blood in case of CD4+ early migration to the tissue (Gulbe et al., 2017), which is indicated by the observation that in the experimental cow group the absolute number of CD4+ cells from day 3 to 7 showed a decreasing trend, while the relative number of $\mathrm{T}$-helpers on day 3 was significantly reduced, due to the emigration of these lymphocytes from the peripheral blood to the udder tissue.

During the study the expression of a cell activation and proliferation marker CD69 in immune cells helps to judge about the state of an activation of T lymphocytes and NK cells (see Fig. 14).

At the beginning of the study, on day 3, data showed (Fig. 14) that the number of CD69+ positive cells significantly decreased $(p<0.001)$ and the amount of these cells on day 21 was still considrably lower than before the infusions $(p<0.01)$, which probably indicates that the migration of activated lymphocytes to the mammary gland had occured. The lowest levels of NK and CD69+ cell counts in the cow blood both in the experimental and control groups were on day 7, while on day 21 , the number of these cells in the GLP 810 study group showed an upward trend.

The inflammatory reactions in the mammary glands were long-lasting. Using milk leukocyte differential counting, we observed that the changes after GLP 810 infusions in PMNL count (increase by 50-60\%), lymphocyte (increase by $60 \%$ ) and macrophage (decrease by $65 \%$ ) count lasted during the entire observation, i.e., from day 3 to day 14 . In the control group, there were significant changes in the distribution of cells, where the number of PMNL had increased by $50-60 \%$, and the number of macrophages decreased by $30-75 \%$, lasted until day 7 , but returned to baseline on day 14 .

The immune cell kinetics described above enlightens cellular immunity as an early response to the application of the immunomodulatory composition in the mammary gland. We observed features of an activating humoral immunity as late as on the 21 st day of the study.

The amount of CD4+ in blood, as reported previously (Asai et al., 1998), correlates with CD25+ positive cells are IL-2 receptor-bearing cells (see Fig. 15). IL-2 is known to stimulate the growth and differentiation of B lymphocytes, to activate NK cells, to trigger T lymphocyte activation, and to promote lactoferrin secretion. Consequently, IL-2 plays an important part in the acquired immune response (Malek, Castro, 2010).

We also observed a trend in the reduction of the number of CD4+, CD8+ and CD25+ cells in the composition GLP 810 research, while on the 21st day, 
the amount of IL-2 receptor-bearing cells increased rapidly compared to day 7 $(p=0.000)$, indicating a late activation of $\mathrm{T}$ lymphocytes in the peripheral bloodstream. In addition, the proliferation of CD25+ cells is also likely to have an effect on B lymphocyte activation, as evidenced by the increase in the absolute number of CD19+ cells in the cow blood of the experimental group on day 21 (vs. day 7).

\subsection{Expression of the inflammatory cytokines}

To measure the progress of inflammation in the mammary glands, immunoreactive cells were labeled and interleukin 1 (IL-1), tumor necrosis factor-alpha (TNF- $\alpha$ ), interleukin 10 (IL-10), beta-defensin 2 (BD-2) and caspase-6 expression were identified in leukocytes.

IL-1 and TNF- $\alpha$ are major inflammatory cytokines and are involved in both local and systemic immune responses through stimulating neutrophil leukocyte chemotaxis from the peripheral bloodstream to the mammary tissue where they arrive several minutes after the onset of infection (Rainard, 2000 Alluwaimi, 2004; Oviedo-Boyso et al., 2007; Abbas et al., 2014). The presence of TNF- $\alpha$ was not detected in healthy mammary glands (Bannerman, 2009).

At the start of the study, prior to the infusions of preparations, we found the TNF- $\boldsymbol{\alpha}$ immunoreactive cells, mainly macrophages, in milk of both cow groups. These cells were found to be present in small amounts at similar frequencies (16-25\%), without any correlation to a number of SCC and pathogenic bacteria. As shown in Figure 16, when starting the infusion of GLP 810, the expression of TNF- $\alpha$ in experimental mammary glands in general increased by approx. 130\% and in the following period from day 3 to day 7 remained unchanged at high levels, indicating the importance of this cytokine in maintaining inflammation, that is, maintaining PMNL activity, as the number of PMNLs in milk had significantly elevated during the period from day 3 to day 7 . It is known that neutrophils are the major producers of TNF- $\alpha$ during inflammation.

We revealed that the expression of TNF- $\alpha$ was significantly higher in the samples with high SCC (average $3.4 \pm 0.3 \times 10^{-6}$ cells $\mathrm{mL}^{-1}$ ) than in the samples with low SCC (average $72.0 \pm 8.4 \times 10^{-3}$ cells $\mathrm{mL}^{-1}$ ). Besides cytokine release from immune cells from the day 1 was detected only in milk samples where somatic cells comprised more than 10\% of PMNL and lymphocytes - less than $10 \%$. Such a leukocyte distribution in milk characterises an infected mammary gland (Alhussien et al., 2015).

IL-1, the same as TNF- $\alpha$, is an inflammatory cytokine, but it is known that IL-1 involvement in mastitis pathogenesis is not decisive and its significance is influenced by the type of infectious agent (Shuster, Kehrli, 1995, Alluwaimi, 2004). 
After infusions of composition GLP 810, the expression of IL-1 in immune cells was gradually reduced and on day 7 it was about $80 \%$ less than in the baseline (see Fig. 17).

IL-1 release is thought to be reduced due to (1) a decrease in macrophages, (2) an increased anti-inflammatory cytokine IL-10 releases, as well as, (3) an increased activity of an apoptosis. The apoptosis in the mammary glands is indicated by the increase in the expression of caspase- 6 immune reactive cells on day 3 by about $60 \%$, and by the decrease in the number of macrophages by an average of $65-70 \%$ from day 3 to day 7 .

Other authors also confirm that the main distributors of IL-1 are monocytes in blood and macrophages in milk, but in a case of apoptosis, the amount of IL-1 decreases (Alluwaimi, 2004; Lopez-Castejon, Brough, 2011).

From the dynamics of analyzed inflammatory cytokines (IL-1 and TNF- $\alpha$ ) we can conclude that the applied composition GLP 810 had caused controlled inflammatory reactions in the mammary glands, decreasing the count of pathogenic microorganisms, and at the same time limiting epithelial cell damage.

Beta defensin-2 (BD-2) is characterized by bactericidal effects on pathogenic microorganisms and immunomodulatory action within both specific and non-specific immunity. Beta-defensins promote broad-spectrum leukocyte chemotaxis to the inflammatory site (Luenser, Ludwig, 2005; Meade et al., 2014).

The expression of BD-2 in terms of frequency and intensity in leukocytes in the milk of the experimental cow group had increased already on resarch day 3 , but significantly increased on day 7 , when secretion of $80 \%$ of the mammary glands had been disturbed and most of the milk samples (93.3\%) contained BD-2 positive cells (see Fig. 18).

The milk, obtained on the research day 7 , is characterized also by the lowest total number of conditionally pathogenic bacteria, the lowest number of S. aureus, the bacteria from Enterobacteriaceae family and the Staphylococcus spp. We conclude that the BD-2 activity after infusion of GLP 810 increased, and it had the significant role in the elimination of pathogenic bacteria, as well as in promotion of PMNL and lymphocyte migration to the mammary glands. We found with a variable frequency BD-2-positive immune cells in the milk samples of the control group, but the observed changes were statistically insignificant.

IL-10 plays a key role in inhibiting inflammation and its action has a protective effect on limiting tissue damage and promoting tissue renewal after infections (Asadullah et al., 2003; Bannerman, 2009).

We found that simultaneously with the increase of the number of PMNL, the frequency and intensity of IL-10 expression in the cow milk samples of the experimental group significantly increased during the study. The highest activity of the IL-10 expression was observed on day $7(p<0.01)$ in almost all (18 out of $19)$ milk samples of experimental cow group. Besides in the majority $(58 \%)$ of 
IL-10-positive cells, the cytokine were present even at already moderate concentrations. In the milk samples of control cow group, the expression of IL-10 showed a decreasing trend during the study (see Fig. 19).

The role of IL-10 in reducing inflammation is confirmed by the fact that the expression of this immunity regulating cytokine was significantly higher in milk with elevated somatic cell count (Kendall coeff. 0.774, $p=0.000$ ) and elevated total bacterial count (Kendall coeff. 0.676, $\mathrm{p}=0.005$ ).

It was observed in vitro studies that IL-10 inhibits the proliferation of CD4+ cells and production of cytokines in these cells, mainly affecting the Th1 lymphocyte subpopulation. IL-10 does not act suppressively on CD8+ cells, and under certain conditions even activating immune regulatory $\mathrm{T}$ lymphocytes. In contrast, the effect of the anti-inflammatory cytokine on NK cells is primarily stimulating, improving the cytotoxic activity of these cells (Asadullah et al., 2003).

Our study proved that IL-10 activity in the cow mammary glands of the experimental group provided a balanced inflammatory response which included the activation of the cellular immunity locally in the mammary glands, and lasted until day 14 of the study (or 9 days after the last infusion) resulting in a decrease in the number of pathogenic bacteria and number of somatic cell count.

Consequently, the hypothesis of the doctoral thesis has been proved that using natural immunomodulatory properties intramammarily in cows can activate the local and the systemic immune responses of the body which results in limitation of growth of pathogenic bacteria in the mammary glands. In addition, we found that by immunomodulatory composition GLP 810 the proposed immunomodulation was balanced, including the simultaneous migration of phagocytic cells to the udder tissue and the release of antiinflammatory factors, providing controlled activation of cellular immunity in the range of physiological norm between day 3 and day 7 , as well as the possible activation of humoral immunity on the 21 st day of the study. 


\section{CONCLUSIONS}

1. The obtained milk samples from the organic dairy herds that do not meet the raw milk quality requirements (i.e. when the amount of TBC in milk exceeded $100 \mathrm{cfu} \times 10^{-3} \mathrm{~mL}^{-1}$ ) most often found in autumn (21.0\%) and winter (20.6\%) while in spring and summer the number of non-conforming samples amount to $11.9 \%$ and $8.3 \%$ respectively. The highest number of mean TBC was found in the samples obtained in autumn $\left(243 \pm 644 \mathrm{cfu} \times 10^{-3} \mathrm{~mL}^{-1}\right)$, while in other seasons the bacterial contamination of milk was significantly lower $\left(72 \pm 11 \mathrm{cfu} \times 10^{-3} \mathrm{~mL}^{-1}\right.$ in winter, $57 \pm 16 \mathrm{cfu} \times 10^{-3} \mathrm{~mL}^{-1}$ in spring and in summer $-24 \pm 11 \mathrm{cfu} \mathrm{x} 10^{-3} \mathrm{~mL}^{-1}$ ). The highest levels of bacteria in milk is observed in large herds $\left(180 \mathrm{cfu} \times 10^{-3} \mathrm{~mL}^{-1}\right)$, lower total bacterial count - in the small herds $\left(48 \mathrm{cfu} \times 10^{-3} \mathrm{~mL}^{-1}\right)$, but the smallest number of bacteria is found in the medium-sized herds $\left(31.0 \pm 5.0 \mathrm{cfu} \times 10^{-3} \mathrm{~mL}^{-1}\right)$. The presence of some bacteria, i.e., K. kristinae and Corynebacterium spp., is characteristic of the milk from the small herds, while microorganisms of the family Enterobacteriaceae are isolated primarily from the large herd milk.

2. Prevalent microorganisms in milk are coagulase-negative staphylococci (CoNS) 30.9\%, S. aureus 25.2\%, bacteria of Enterobacteriaceae family $13.7 \%$ and K. kristinae $13.1 \%$. Micrococcus spp., Corynebacterium spp., Streptococcus spp. and Bacillus spp. (4.3-7\%) were isolated less frequently. S. aureus with $739 \pm 96$ cells $\times 10^{-3} \mathrm{~mL}^{-1}$, Corynebacterium spp. with $1059 \pm 464$ cells $\times 10^{-3} \mathrm{~mL}^{-1}$ and $S$. aureus in association with Enterobacteriaceae $\left(1607 \pm 405\right.$ cells $\left.\times 10^{-3} \mathrm{~mL}^{-1}\right)$ cause the most severe increase in milk somatic cell count.

3. The highest antibacterial activity in vitro is demonstrated by lysozyme (15.0 to $19.5 \mathrm{~mm}$ ), lactic acid ( 8.3 to $24.3 \mathrm{~mm}$ ) and lactoferrin $(8.0$ to $11.0 \mathrm{~mm}$ ). The composition GLP 810 (containing lysozyme and lactic acid, in combination with $L$. helveticus glycopeptide), display antagonistic effect on both strains of S. aureus and on E. coli, from 9.0 to $15.0 \mathrm{~mm}$ growth inhibition.

4. The composition GLP 810, administered intramammarily three times with $48 \mathrm{~h}$ intervals, results in the diminishing of the number of pathogenic bacteria in the mammary glands and in the controlled activation of cellular immunity in the range of physiological norm between day 3 and day 7, as well as in the possible activation of the humoral immunity on the 21st day of study:

4.1. after infusions the number of pathogen-free mammary glands significantly increased (by 73\%) in the experimental group but the number of pathogenic bacteria in milk samples significantly decreased by $87-92 \%$ (from $51 \mathrm{cfu} \times 10^{-3}$ to $4 \mathrm{cfu} \times 10^{-3} \mathrm{~mL}^{-1}$ ). 
The total bacterial count also decreases by 12-24\% (from 525 cells $\times 10^{-3}$ to 398 cells $\times 10^{-3} \mathrm{~mL}^{-1}$ ) possibly due to an increase in the expression of antibacterial peptide BD-2;

4.2. the absolute number of segmented leukocytes in the cow blood of the GLP 810 study group does not substantially change and fits into the physiological norm throughout the study, while the number of PMNL increases in milk, indicating a balanced proliferation of local PMNL in the mammary glands probably provided by the activity of the anti-inflammatory cytokine IL-10;

4.3. in the blood of the GLP 810 study group cows, after the start of infusions, the number of lymphocytes shows the tendency of a decrease, but significantly decreases on the study day 7 , while the number of lymphocytes in the milk significantly increases, which again proves the activation of local immunity;

4.4. the number of CD4+, CD8+ and CD25+ cells in the cow blood in the GLP 810 study group is decreasing, while on the 21 st day there is a rapid increase in the number of the immune regulatory T-lymphocytes and the number of IL-2 receptor-bearing cells indicating late activation of $\mathrm{T}$ lymphocytes in the peripheral bloodstream.

\section{PROPOSALS}

1. Considering the fact that the immunomodulation and diminishing of pathogenic bacteria growth which are observed to a great extent on day 3 after the first infusion, we recommend intramammary infusions of the composition GLP 810 into the subclinically affected mammary glands to be performed once, but if necessary, a repeated infusion after 21 day.

2. In order to avoid a rapid increase in the milk somatic cells count, prior to the administration of the composition GLP 810 it is advisable to check the state of milk secretion and to administer the composition only into the problematic udder quarters (with SCC above $200,000 \mathrm{~mL}^{-1}$ or in latent infected).

3. In order to timely detect subclinical mastitis and to start an appropriate treatment, it is advisable to determine the number of somatic cell count, total bacterial count and lactose content in the milk. We found that of all mastitis cases, $42 \%$ had at the same time an elevated SCC (more than 200 thousand $\mathrm{mL}^{-1}$ ) and $\mathrm{TBC}$ (more than 100 thousand $\mathrm{mL}^{-1}$ ), while $33 \%$ of mastitis cases had an elevated SCC and TBC and at the same time reduced lactose content (less than $4.65 \%$ ) in milk. 